\title{
PROCESSAMENTO DE MILHO E SUPLEMENTAÇÃO COM MONENSINA PARA BEZERROS LEITEIROS PRÉ E PÓS DESMAMA PRECOCE.
}

CARLA MARIS BITTAR NUSSIO

Tese apresentada à Escola Superior de Agricultura "Luiz de Queiroz", Universidade de São Paulo, para obtenção do título de doutora em Agronomia, Área de Concentração: Ciência Animal e Pastagens.

\footnotetext{
PIRACICABA

Estado de São Paulo - Brasil

Janeiro - 2002
} 


\title{
PROCESSAMENTO DE MILHO E SUPLEMENTAÇÃO COM MONENSINA PARA BEZERROS LEITEIROS PRÉ E PÓS DESMAMA PRECOCE.
}

\author{
CARLA MARIS BITTAR NUSSIO \\ Engenheiro Agrônomo
}

Orientador : Prof. Dr. FLÁVIO AUGUSTO PORTELA SANTOS

Tese apresentada à Escola Superior de Agricultura "Luiz de Queiroz", Universidade de São Paulo, para obtenção do título de doutora em Agronomia, Área de Concentração: Ciência Animal e Pastagens.

PIRACICABA

Estado de São Paulo - Brasil

Janeiro - 2002 
Dados Internacionais de Catalogação na Publicação (CIP)

DIVISÃO DE BIBLIOTECA E DOCUMENTAÇÃO - ESALQ/USP

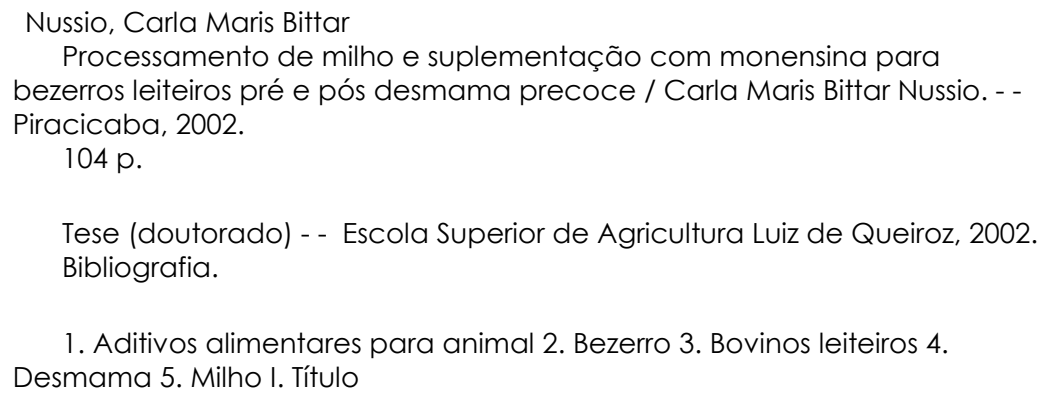

CDD 636.2085

\section{"Permitida a cópia total ou parcial deste documento, desde que citada a fonte - $\mathrm{O}$ autor"}


À memória de Suzana Campos Tauil, amiga sempre presente.

Ao meu filho Vitor, que com seu sorriso me incentiva a continuar...

\section{DEDICO}




\section{AGRADECIMENTOS}

À Escola Superior de Agricultura Luiz de Queiroz (USP), em especial ao Departamento de Produção Animal e seus professores, por auxiliar na minha formação e pela oportunidade de realização desse curso.

À Fundação de Amparo à Pesquisa do Estado de São Paulo (FAPESP), pela concessão da bolsa de estudos e financiamento do projeto.

À Embrapa Pecuária Sudeste, pela concessão de dedicação para finalização desse trabalho.

Ao Prof. Dr. Flávio Augusto Portela Santos pela orientação, confiança e inúmeras oportunidades.

Ao Dr. José Manuel Corrêa de Simas, pela orientação, confiança, amizade, incentivo nas horas difíceis e principalmente pelo exemplo profissional.

Ao Prof. Dr. Alexandre Vaz Pires e ao colega de curso Juliano José de Resende Fernandes pela execução das cirurgias.

Ao Prof. Dr. Irineu Umberto Packer e a colega de curso Cláudia Paro da Paz pela ajuda e orientação nas análises estatísticas.

Aos demais professores do Departamento de Produção Animal, pelos ensinamentos, cordialidade e pela amizade.

Ao Laboratório de Nutrição Animal do Centro de Energia Nuclear na Agricultura (CENA) e à técnica Regina Peçanha pelo auxílio nas análises de insulina.

Ao funcionário do Laboratório de Bromatologia do Departamento de Produção Animal Carlos César Alves, pela amizade e por proporcionar bom ambiente de trabalho durante as análises laboratoriais.

Aos amigos e colegas de curso Éberson de Castilho Barnabé, Hugo Imaizumi, Sérgio de Oliveira Jüchen e Paola Ranzani Gabarra pela amizade e agradável convivência durante os inúmeros experimentos em que trabalhos juntos. 
Aos demais funcionários e colegas do curso de pós-graduação, pela amizade e agradável convivência.

Ao meu filho Vitor e marido Luiz Gustavo pelo amor, carinho e incentivo nessa longa jornada.

Aos meus queridos pais Jorge e Maria Celina, meus irmãos Ernesto, Vladimir e Gabriel, minha avó Albertina e minha sogra Ana Maria pelo carinho, incentivo, e por entenderem minha ausência nos aniversários e almoços de domingo.

Às estagiárias Adriana Ramos de Miranda e Janice Barreto de Morais pela amizade e dedicação fundamentais para condução do experimento no campo.

Principalmente à estagiária Maity Zopollatto pela dedicação na condução dos trabalhos de campo e de laboratório, e pela grande amizade, com quem divido o mérito desse trabalho. 


\section{SUMÁRIO}

Página

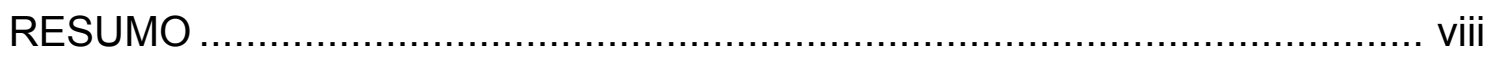

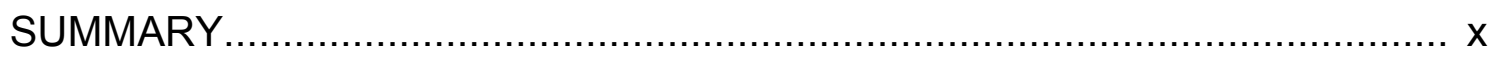

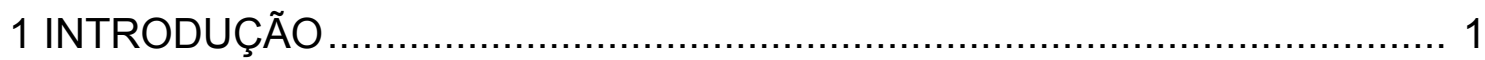

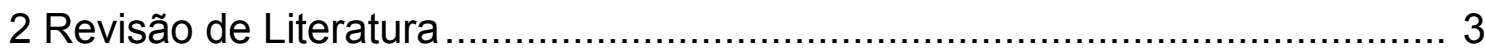

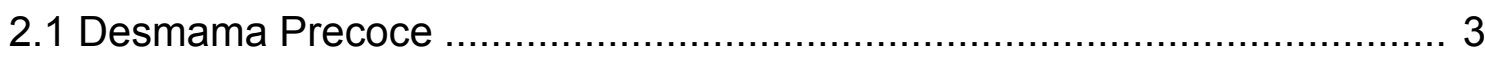

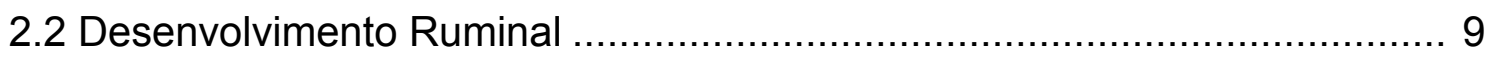

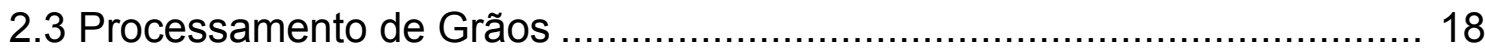

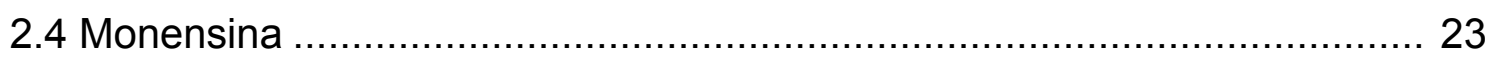

3 PROCESSAMENTO DE MILHO (FLOCULADO vs. LAMINADO A VAPOR) E SUPLEMENTAÇÃO DE MONENSINA PARA BEZERRAS LEITEIRAS, PRÉ E

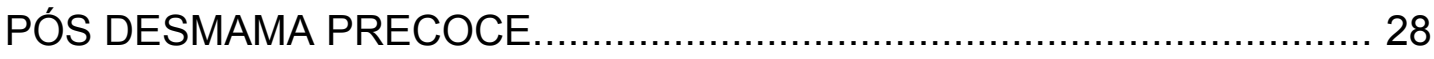

Resumo 28

Summary 29

3.1 Introdução 30

3.2 Material e métodos 32

3.2.1 Animais e Dietas Experimentais 32

3.2.2 Avaliação do alimento 34

3.2.3 Procedimentos de Coleta e Métodos Analíticos 34

3.2.5 Análise Estatística 36

3.3 Resultados e discussão 36

3.4 Conclusões 53

4 DESENVOLVIMENTO RUMINAL E PARÂMETROS SANGUÍNEOS DE BEZERROS LEITEIROS SUPLEMENTADOS COM MILHO PROCESSADO 
(FLOCULADO vs. LAMINADO A VAPOR) E MONENSINA.

55

Resumo 55

Summary 56

4.1 Introdução 56

4.2 Material e métodos 59

4.4.2.1 Animais e Procedimento Cirúrgico 59

4.2.2 Manejo Alimentar e Dietas Experimentais 60

4.2.3 Consumo de Matéria Seca e Análise Bromatológica 61

4.2.4 Procedimentos de Coleta de sangue e Métodos Analíticos 61

4.2.5 Procedimentos de coleta de conteúdo ruminal e métodos analíticos 65

4.2.6 Abate Animal e Medidas morfométricas do Trato Digestivo. 66

4.2.7 Análise Estatística 66

4.3 Resultados e discussão 67

4.4 Conclusões 84

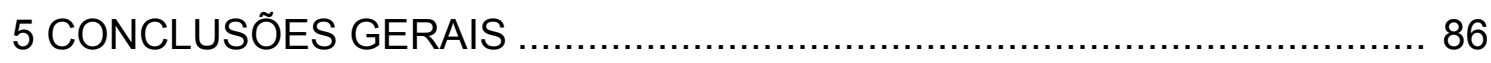

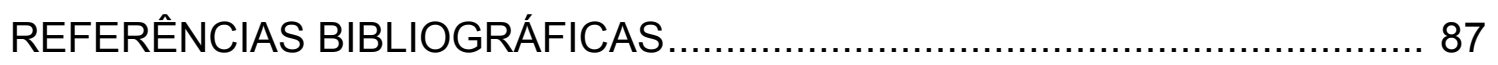




\title{
PROCESSAMENTO DE MILHO E SUPLEMENTAÇÃO COM MONENSINA PARA BEZERROS LEITEIROS PRÉ E PÓS DESMAMA PRECOCE.
}

\author{
Autora: Carla Maris Bittar Nussio \\ Orientador: Dr. Flávio Augusto Portela Santos
}

\section{RESUMO}

Tanto a administração de monensina quanto o processamento de grãos alteram o padrão de fermentação ruminal de forma a aumentar a disponibilidade de energia e proteína para o animal, resultando em melhor desempenho. Dois trabalhos foram conduzidos com o objetivo de avaliar o efeito de concentrados contendo milho laminado a vapor ou floculado, com ou sem a adição de monensina, no consumo de MS, ganho de peso e parâmetros sanguíneos e ruminais de bezerros leiteiras, antes e após a desmama realizada a sexta semana de vida. No primeiro experimento foram utilizadas 32 bezerras holandesas do nascimento a 12 semanas de vida, em um delineamento experimental do tipo blocos ao acaso, com arranjo fatorial $2 \times 2$. Do nascimento a desmama os animais receberam concentrado ad libitum até o consumo de $2 \mathrm{~kg} / \mathrm{d}$, quatro litros diários de leite e tiveram acesso livre à água. Após a desmama, realizada na sexta semana de vida, os animais continuaram recebendo $2 \mathrm{~kg}$ de concentrado e passaram a ter acesso a feno picado ad libitum. $O$ tipo de processamento de grão ou a adição de 
monensina não afetou o consumo médio de concentrado ou feno ( $P>0,05)$, assim como o peso final e o ganho de peso diário $(P>0,05)$. As concentrações plasmáticas de glicose e AGL médios do período experimental não foram afetadas pelos tratamentos; entretanto, as concentrações de N-uréico foram inferiores no plasma de animais recebendo concentrado com grãos laminados e monensina $(P=0,08)$. Houve efeito significativo da idade animal nas concentrações plasmáticas de glicose $(P<0,0001)$, N-uréico $(P<0,001)$ e $A G L(P<0,02)$. Somente os parâmetros glicose e AGL plasmáticos foram afetados pelo horário após 0 fornecimento do alimento. No segundo experimento, 16 bezerros holandeses fistulados no rúmen com 3 a 5 dias de vida, foram agrupados em blocos ao acaso, com arranjo fatorial $2 \times 2$. Os animais receberam concentrado ad libitum até o consumo de $2 \mathrm{~kg} / \mathrm{d}$, 4 litros diários de leite e tiveram acesso livre à água. Após a desmama, realizada na oitava semana de vida, os animais passaram a receber 2 $\mathrm{kg} / \mathrm{d}$ de concentrado e feno picado ad libitum. Os tratamentos não afetaram $(P>0,05)$ o consumo de concentrado e feno, assim como o desempenho animal. $A$ concentração molar de propionato $(P<0,05)$ foi maior para animais recebendo grão laminado. Houve tendência de maior concentração molar de AGV total $(P=0,11)$ e butirato $(P=0,13)$ para animais recebendo grão laminado. $A$ inclusão de monensina tendeu a reduzir as concentrações de $\mathrm{N}-\mathrm{NH}_{3}$ ruminal $(\mathrm{P}=0,12)$. O peso do retículorúmen ( $\%$ trato total) tendeu $(P=0,09)$ a ser maior em animais recebendo grão laminado e monensina. A capacidade do retículo-rúmen foi aumentada $(P<0,05)$ pelo fornecimento de grão laminado e monensina. Milho floculado resultou em menor peso do abomaso em $\%$ trato total $(P<0,01)$. 


\title{
CORN PROCESSING AND MONENSIN SUPPLEMENTATION FOR DAIRY CALVES, PRE AND POST EARLY-WEANING
}

\author{
Author: Carla Maris Bittar Nussio \\ Adviser: Prof. Dr. Flávio Augusto Portela Santos
}

\section{SUMMARY}

Two trails were conducted to evaluate the effects of concentrates containing processed grains (steam-flaked vs. steam-rolled), with or without monensin, on intake, weight gain and blood and rumen parameters of baby calves, before and after weaning at six weeks of life. In the first trial, 32 baby heifers were utilized on a completely randomized block, with a $2 \times 2$ factorial arrangement. The animals received concentrate ad libitum up to $2 \mathrm{~kg} / \mathrm{d}$, plus $4 \mathrm{~L}$ of milk. Calves had free access to water. After weaning, at the sixth week of life, calves received concentrate and chopped hay. The treatments did not affect $(P>0,05)$ concentrate or hay intake, final live weight, average daily gain, plasma glucose and NEFA concentration. PUN was lower on calves fed steam-rolled corn and monensin $(P=0,08)$. There was a significant effect of age on glucose $(P<0,0001)$, PUN $(P<0,001)$, and NEFA $(P<0,02)$ concentrations. Only glucose and NEFA were affected by time after feeding. In the second trial, Sixteen Holstein calves were ruminally canulated with 3 to 5 days of life, and utilized on a completely randomized design block with a $2 \times 2$ factorial arrangement. The animals received concentrate ad libitum up to $2 \mathrm{~kg} / \mathrm{d}$, plus $4 \mathrm{~L} / \mathrm{d}$ of milk. Calves had free access to water. After weaning at the eight weeks of life, calves received concentrate and chopped hay. 
Animal performance, concentrate and hay intakes were lower than expected and not affected $(P>0,05)$ by treatments. The molar proportion of propionate was higher $(P<0,05)$ for steam-rolled concentrate. There was a tendency for higher total VFA $(P=0,11)$ and butyrate $(P=0,13)$ for steam-rolled corn. Monensin tended to reduce ruminal $\mathrm{N}-\mathrm{NH}_{3}$ concentration ( $\left.\mathrm{P}=0,12\right)$. Weight of reticulum-rumen (as $\%$ total tract) tended to be higher $(P=0,09)$ for calves on steam-rolled and monensin concentration. However, the capacity of reticulum-rumen was increased by steamrolled and monensin feeding $(P<0,05)$. Steam-flaked concentrate resulted on heavier abomasum, as \% total tract $(P<0,01)$. 


\section{INTRODUÇÃO}

O alto custo de produção de animais em crescimento, principalmente na fase de aleitamento, tem levado à busca de técnicas que possibilitem a desmama precoce sem que ocorram reduções no desempenho animal. Para que a desmama precoce ocorra com sucesso o bezerro deve apresentar o rúmen parcialmente desenvolvido, capaz de digerir alimento sólido e assim manter ganho de peso satisfatório. $\mathrm{O}$ desenvolvimento do rúmen está fortemente associado ao consumo de matéria seca. $O$ fornecimento de dietas que promovem alta concentração de ácido butírico no rúmen, leva ao aumento da taxa de maturação deste órgão, já que este ácido influencia a atividade metabólica do epitélio ruminal.

Devido à alta taxa de mortalidade por problemas de diarréia em bezerros em aleitamento, o fornecimento de coccidiostáticos tem aumentado em sistemas de produção de leite. Alguns dos coccidiostáticos utilizados na criação de bezerras, como lasalocida e monensina, são também ionóforos, produtos que otimizam o desempenho de animais em crescimento. Ionóforos atuam no rúmen selecionando bactérias com maior produção de propionato, mas menor produção de lactato, acetato e butirato. Os efeitos do fornecimento destes produtos para pré-ruminantes não são conhecidos mas devem alterar o desenvolvimento do rúmen devido a mudanças no padrão de fermentação. Apesar de resultados não serem sempre consistentes, dados de literatura mostram melhores ganhos de peso e conversão alimentar de bezerros recebendo ionóforos na dieta. O modo de ação de ionóforos em bezerros em aleitamento e com o rúmen em desenvolvimento, ainda é pouco estudado, e permanece por ser esclarecido.

O processamento de grãos também é uma importante ferramenta de 
manipulação da fermentação ruminal. Os trabalhos de pesquisa têm mostrado que a floculação de milho ou sorgo aumenta a utilização de amido por animais ruminantes, uma vez que o rúmen passa a ser seu principal sítio de digestão. $\mathrm{O}$ aumento da disponibilidade de amido no rúmen, resultante da floculação, aumenta a produção total de ácidos graxos voláteis (AGV), principalmente propionato e estimula a síntese de proteína microbiana. Embora o uso de grãos floculados em dietas de animais em crescimento venha aumentando, dados de desempenho de bezerros são escassos, e estudos com relação a possíveis diferenças na fermentação ruminal são inexistentes.

As mudanças nos padrões de fermentação do rúmen provocadas por dietas contendo grãos processados de formas distintas e a administração de ionóforos, devem ter efeito sobre o desenvolvimento do rúmen, já que este é dependente da ação de AGV. O estudo desses efeitos é essencial já que a garantia de bom desempenho após a desmama depende de um animal totalmente desenvolvido do ponto de vista fisiológico. 


\section{REVISÃO DE LITERATURA}

\subsection{Desmama Precoce}

Alguns dos programas de manejo nutricional de animais em aleitamento, têm recomendado o aumento na quantidade de leite, de forma a se obter maiores ganhos de peso com melhor eficiência (Davis \& Drackley, 1998). Entretanto, não está claro se o maior de dieta líquida resulta em melhor crescimento a longo prazo, maior produção de leite futura, e maturidade sexual e concepção mais precoces. Segundo Quigley (1999), hipoteticamente o aumento nas quantidades de leite ou de substituto fornecidas pode afetar de forma positiva o crescimento e desenvolvimento antes da desmama, beneficiando a vida produtiva futura deste animal. No entanto, dados de pesquisa sinalizando este tipo de resposta não são conclusivos e não representam práticas de manejo utilizadas frequentemente. Além desses fatores, o aumento no custo da dieta e a relação entre dieta líquida e desenvolvimento ruminal devem ser considerados. Dessa forma, aproximadamente $90 \%$ dos produtores de leite americanos têm fornecido quantidades limitadas de leite para bezerros, realizando a desmama por volta de 8 semanas de vida do animal (National Animal Health Monitoring System, 1993).

A desmama precoce é uma ferramenta de manejo muito importante do ponto de vista econômico na produção de fêmeas de reposição. O custo de alimentação dos animais é reduzido com a retirada do leite e com a introdução de misturas concentradas como dieta principal. Adicionalmente, o menor tempo demandado para a alimentação desses animais reduz o custo com mão-de-obra.

Segundo Quigley (1996 b), o animal está pronto para a desmama, do ponto 
de vista fisiológico, quando atinge o consumo de $700 \mathrm{~g} / \mathrm{d}$ de concentrado durante três dias consecutivos. Fatores como a forma física do concentrado, tamanho do animal, disponibilidade de água e qualidade da dieta líquida (fonte de proteína), afetam o consumo de concentrado de bezerros. Entretanto, a quantidade de leite, ou substituto, fornecida ao animal parece ser o mais importante. O trabalho de Tomkins et al. (1995) demonstrou que embora o consumo de concentrado apresentasse tênues aumentos, não houve acréscimos significativos até que a quantidade de MS, proveniente de substituto de leite, fosse reduzida. Entretanto, Jenny et al. (1982) já haviam demonstrado que o volume de dieta líquida e não a quantidade de MS proveniente desta, é que afeta o consumo de concentrado em bezerros jovens.

Observa-se a campo que pelo menos três diferentes critérios para desmama são utilizados por produtores, sendo eles: 1) consumo de concentrado; 2 ) idade do animal; e 3) peso do animal.

A utilização do consumo diário como critério de desmama tem limitações uma vez que o consumo a uma certa idade depende do peso do animal. Leaver \& Yarrow (1972) compararam três níveis de consumo para desmama e observaram que o consumo de $400 \mathrm{~g} / \mathrm{d}$ foi adequado e reduziu dias à desmama quando comparado com consumos de 650 e $900 \mathrm{~g} / \mathrm{d}$. O uso deste critério parece inadequado quando se compara o consumo de animais de raça de porte diferente (Holandês vs. Jersey); e estes autores demonstraram que o acréscimo de $10 \mathrm{~kg}$ no peso ao nascer reduziu o número de dias necessários para se alcançar o consumo em 6,8 dias. O critério consumo para desmama implica em bezerros mais leves devendo apresentar um consumo maior em percentagem de seu peso vivo, sugerindo-se que as recomendações devessem se basear em consumo como \% de peso ao nascer (PN).

Greenwood et al. (1997) testaram 3 níveis de consumo em \% do peso ao nascer $(P N)(1,1,5$ e 2\%) como critério de desmama, com o objetivo de reduzir a variação na idade a desmama. Os autores observaram um aumento no número de 
dias para a desmama com o aumento na meta de consumo em \% PN. Entretanto, o número de dias necessários para que o consumo fosse de 1,5 e 2\% PN não foi estatisticamente diferente, demonstrando que pode haver um platô para o consumo necessário a desmama. O ganho de peso dos animais desmamados em idade mais jovem ( $1 \% \mathrm{PN}$ ) não foi negativamente afetado uma vez que apresentou o maior consumo total de concentrado.

De maneira a facilitar o manejo de animais em aleitamento, a desmama vem sendo realizada baseada na idade do animal, idade esta em que o consumo deve ter alcançado níveis adequados. Um levantamento americano mostra que $43 \%$ dos produtores adotam a idade do animal como critério de desmama, enquanto que 26,4 e 26,9 adotam o peso animal e o consumo de grãos, respectivamente. 0 restante dos produtores $(3,7 \%)$ adota outros critérios não mencionados no levantamento (National Animal Health Monitoring System, 1993). Adotando-se estes critérios, a idade média de bezerros na ocasião da desmama é de 7,9 ( \pm $0,1)$ semanas. Entretanto, segundo Quigley (1999) a maior parte dos animais recebendo quantidades limitadas de leite apresentarão consumo de concentrado suficiente para manter o funcionamento do rúmen com aproximadamente 28 dias, quando há disponibilidade deste desde os primeiros dias de vida. Segundo o autor, o aumento no consumo de concentrado apresenta uma tendência associada à limitação da dieta líquida e o aumento na idade do animal. Dessa forma, em sistemas bem manejados a desmama pode ser realizada com sucesso com animais de 4 a 6 semanas de vida, o que implica em maior observação individualizada e atenção do que em sistemas com desmama mais tardia.

Winter (1985) comparou o desempenho de animais desmamados de forma abrupta com 3, 5 e 7 semanas de vida. $O$ autor não observou efeito negativo no desempenho dos animais em função de idade de desmama. O grupo desmamado em idade mais jovem apresentou ganho de peso reduzido nas duas semanas seguintes a desmama. Entretanto, nas semanas seguintes o ganho de peso foi 
comparável ao ganho dos outros grupos. Na semana da desmama, o consumo de concentrado dos animais com desmama à $3^{a}$ semana foi de apenas $257 \mathrm{~g} / \mathrm{d}$, valor este abaixo do recomendado na literatura. Todavia, o consumo destes animais aumentou para $914 \mathrm{~g} / \mathrm{d}$ na semana seguinte ( $4^{\mathrm{a}}$ semana) e foi ainda superior na $5^{\mathrm{a}}$ (1300 g/d). Os dados de digestibilidade da dieta, assim como os dados de produção de AGV no rúmen na semana da desmama, não foram diferentes quando se comparou a idade a desmama. Segundo os autores, estes dados indicam que animais recebendo dieta com alta energia desenvolvem a capacidade de digestão de alimento tão cedo quanto à $3^{a}$ semana de vida, permitindo uma desmama precoce.

Em dois trabalhos subseqüentes Quigley et al. (1991 a e b) avaliaram os efeitos de idade a desmama e consumo de matéria seca nos parâmetros sanguíneos de bezerros. Os animais foram desmamados com 28 ou 56 dias de vida, recebendo concentrado a partir da primeira semana (28 d) ou apenas após 28 dias de vida (56d), até o consumo atingir $2,7 \mathrm{~kg} / \mathrm{d}$, quando também passaram a receber feno de alfafa. O desempenho animal não foi diferente entre os tratamentos e as diferenças no consumo de fontes de nutrientes (leite $\times$ grão) refletiram o tratamento adotado. Houve tendência de menor nível de glicose plasmática em animais desmamados em idade mais jovem. As concentrações de glicose foram inicialmente típicas de animais monogástricos, mas chegaram a valores mais baixos por volta da $9^{a}$ semana. As concentrações de ácidos graxos livres não foram afetados pela idade a desmama ou consumo de concentrado no período total, mas foram menores para bezerros desmamados aos $28 \mathrm{~d}$ no período entre 5 e 8 semanas. Por outro lado, as concentrações de BHBA foram maiores em bezerros desmamados aos $28 \mathrm{~d}$ durante todo o período experimental, estando fortemente relacionadas ao consumo de concentrado. Os níveis de AGVT plasmáticos foram praticamente inalterados durante as 3 primeiras semanas em ambos grupos, aumentando rapidamente após a $4^{a}$ semana nos animais desmamados em idade mais jovem. As concentrações de AGVT também foram 
altamente correlacionados com consumo de concentrado, indicando que seu aumento foi conseqüência de fermentação de substrato ocorrendo no rúmen. Os níveis de acetato, propionato e butirato, foram inferiores na pré-desmama em relação a pós desmama em ambos tratamentos. Após a desmama, as concentrações de acetato e butirato foram superiores para animais desmamados aos $28 \mathrm{~d}$. O aumento nos níveis de propionato no plasma após a desmama, indica um aumento na contribuição de glicose circulante a partir de gluoconeogênese, condição típica de animal ruminante. As mudanças nos níveis de metabólitos plasmáticos foram indicativas do desenvolvimento ruminal em termos de capacidade fermentativa, e sugerem que ocorre uma rápida adaptação fisiológica após a desmama precoce.

Quigley (1996c), observou os efeitos no consumo de alimento, crescimento corporal e parâmetros metabólicos de bezerros da raça Jersey, desmamados precocemente por três métodos: 1) desmama abrupta aos 35 dias; 2) desmama gradativa aos 35 dias e 3) desmama quando o consumo fosse de $454 \mathrm{~g}$ por dois dias consecutivos. O ganho de peso de animais que sofreram desmama gradativa foi inferior ao de outros tratamentos uma vez que o consumo reduzido de substituto de leite não resultou em aumento suficiente no consumo de concentrado. Os animais do tratamento 3 foram desmamados com idade média de 40 dias de vida, quando o consumo de concentrado alcançou a meta de $454 \mathrm{~g}$ durante dois dias. Os dados de parâmetros sanguíneos refletiram o padrão de consumo de concentrado, não havendo diferenças entre os diferentes métodos de desmama. Uma rápida análise mostrou que a desmama realizada de acordo com o consumo de concentrado levou a desmamas mais tardias e com maior custo. $O$ autor sugere também que animais de menor porte, como bezerros da raça Jersey, podem ser desmamados com base em um consumo de concentrado menor que $700 \mathrm{~g} / \mathrm{d}$, no caso $454 \mathrm{~g} / \mathrm{d}$ sem que ocorra redução no desempenho animal. Este trabalho confirma a sugestão de Greenwood et al. (1997a) de se realizar a desmama de acordo com o consumo de concentrado referente a \% do PN do bezerro. 
A adaptação do animal ao alimento sólido é fundamental para que a desmama ocorra com sucesso. A mudança na forma física do principal componente da dieta (retirada de um alimento líquido de alta palatabilidade) também é um fator de estresse para o animal. Algumas práticas de manejo têm sido realizadas com o intuito de se encorajar o consumo de concentrado pelo animal como o fornecimento de parte do concentrado no fundo de um balde juntamente com o fornecimento de leite. Entretanto, não está claro se o estímulo ao consumo de concentrado através dessas práticas se deve ao manejo alimentar ou a adaptações metabólicas.

Luchini et al. (1993) utilizaram-se dessa prática comparando 3 regimes de alimentação: fornecimento de leite, fornecimento de leite com suplemento no fundo do balde e fornecimento de leite após "drenching" com o suplemento. Os tratamentos foram aplicados no período entre 19 e 26 dias de vida, quando ocorreu a desmama, sendo os animais alocados em dietas com alta ou baixa energia após esse período. Os dados de peso e ganho de peso mostram que bezerros que receberam "drench" apresentaram melhor desempenho durante o todo o período. Entretanto, o consumo de concentrado foi semelhante para os tratamentos indicando que o manejo pré-desmama tem pequeno efeito no consumo no período pós-desmama. O consumo pós-desmama é mais dependente da adaptação fisiológica à dieta de grãos do que do manejo alimentar aplicado na pré-desmama.

A desmama é um fator de estresse para o bezerro o qual é forçado a várias mudanças: 1) sua principal fonte de nutrientes muda da forma liquida para a forma sólida; 2) a quantidade de matéria seca que o animal recebe é diminuída com o não fornecimento do leite; 3 ) o bezerro deve se adaptar ao tipo de digestão e fermentação própria de ruminantes; 4) mudanças de manejo e instalações geralmente ocorrem juntamente com a desmama (Quigley, 1996 a). Segundo Morrill (1999), a maior parte dos produtores superestima a maturidade do animal no período de transição (logo após a desmama), um dos períodos de maior estresse na vida animal. $O$ autor frisa que bons programas de manejo para 
bezerros em período de transição devem ser desenvolvidos baseados principalmente na redução de estresse imposto ao animal. É de primordial importância que práticas como descorna, castração (no caso de machos), mudança no tipo de concentrado, e de instalações, não ocorram no mesmo dia da desmama. A desmama por si só é um grande fator de estresse.

A adaptação do animal à fermentação ruminal é essencial para que a taxa de crescimento animal não seja afetada. Para isso, o animal deve ter o rúmen parcialmente desenvolvido e capaz de absorver e metabolisar produtos finais da fermentação antes da desmama.

\subsection{Desenvolvimento Ruminal}

O desenvolvimento de bezerros recém-nascidos à condição de ruminante funcional, envolve uma série de mudanças anatômicas e fisiológicas do aparelho digestivo (Beharka et al., 1998). Embora o desenvolvimento do aparelho digestivo desses animais seja inato, a idade do animal per se tem pouco efeito no desenvolvimento das papilas ruminais.

Ao nascer estes animais apresentam o retículo-rúmen pouco desenvolvido e não funcional, representando apenas $30 \%$ do total dos quatro compartimentos (Tabela 1). As maiores mudanças em termos de desenvolvimento vão ocorrer no retículo-rúmen, o qual será colonizado por diferentes tipos de bactérias e terá sua musculatura e parede interna (papilas) desenvolvidas, como também enzimas funcionais na parede do rúmen. Por volta de 3 a 4 semanas, dependendo da alimentação do animal, o retículo-rúmen passa a corresponder a $60 \%$ do total dos quatro compartimentos, enquanto que o abomaso somente a $27 \%$. Um animal com mais de 12 semanas de vida, apresenta o sistema digestivo próprio de um ruminante, sendo o retículo-rúmen $85 \%$ e o abomaso apenas $7 \%$ do total dos quatro compartimentos. 
Tabela 1. Mudanças com a idade nas proporções de compartimentos do trato digestivo de bezerros recebendo leite e concentrado.

\begin{tabular}{lll}
\hline Idade & Retículo-rúmen + omaso & abomaso \\
\hline Nascimento aos 21 dias & $30 \%$ & $70 \%$ \\
22 aos 56-84 semanas & $60 \%$ & $27 \%$ \\
Mais de 84 dias & $85 \%$ (s/ omaso) & $7 \%$ \\
\hline
\end{tabular}

Adaptado de Crowley et al. (1991)

Para que o desenvolvimento do sistema digestivo do recém-nascido ocorra algumas condições devem ser atendidas: 1) estabelecimento de microrganismos no rúmen; 2) presença de líquido; 3) fluxo de material do rúmen para fora do rúmen; 4) capacidade de absorção do tecido; 5) substrato disponível.(Quigley (1996b).

Ao nascer, o rúmen de bezerros é totalmente desprovido de bactérias ou protozoários, característicos da população microbiana de ruminantes. Sua exposição a esta população durante e após a parição contribuem para a colonização do rúmen. $O$ contato animal-animal parece ser o mais importante para o estabelecimento de microrganismos, embora as fontes sejam as mais diversas como a saliva da mãe, esterco, cama, ou leite e outros alimentos (Yokoyama \&Johnson, 1988).

Trabalhos tentando avaliar a seqüência de estabelecimento de bactérias no rúmen de bezerros mostram que com 1 dia de vida, já pode ser encontrada uma grande quantidade de bactérias aeróbias. Este tipo de população se mantém em animais alimentados apenas de leite até que grãos sejam fornecidos, independentemente da idade do animal, sendo substituídas por bactérias anaeróbias. A atividade celulolítica aumenta gradualmente até a sexta semana de vida, quando alcança níveis de um ruminante adulto.

Em trabalho onde foi realizado o isolamento de bactérias do rúmen de 
bezerros de diferentes idades, a seguinte seqüência de aparecimento foi observada : Semana 1 - Butirivibrio ; Semana 3 - Ruminococcus ; Semana 6 Bacteróides succinogenes, B. ruminicula, Selenomonas. A maior parte das bactérias presente no rúmen de animais com até 3 semanas de idade é diferente daquela encontrada em um ruminante adulto. Com 6 semanas são encontradas bactérias presentes em um adulto, além de outras atípicas ao mesmo, e com 9 ou 13 semanas a população deve refletir a população de um ruminante adulto. A composição da dieta influem na composição da população microbiana no rúmen. Beharka et al. (1998), observaram que animais consumindo dieta moída, apresentaram maior contagem de bactérias anaeróbias do que aqueles consumindo dieta não moída. Da mesma forma, o fornecimento de dieta moída resultou em menor contagem de celulolíticas e maior de amilolíticas que a dieta não moída.

O adequado estabelecimento de microrganismos no rúmen e o processo de fermentação de substrato dependem da presença de água no meio. Somente em meio aquoso parte do alimento será solubilizado, possibilitando o início do processo fermentativo. A importância do fornecimento de água para bezerros desde os primeiros dias de vida tem sido demonstrada na literatura. A disponibilidade de água estimula o consumo de concentrado (Kertz et al., 1984), o qual é primordial para o desenvolvimento do rúmen e promove o aumento no consumo total de alimento (Thickett et al., 1981). O trabalho de Kertz e colaboradores (1984) demonstrou que bezerros com acesso restrito à água apresentam consumo de concentrado e desempenho $31 \%$ e $38 \%$, respectivamente, menores que animais com água disponível.

O desenvolvimento do sistema digestivo também é dependente da habilidade deste se contrair, possibilitando o fluxo de fluído ruminal (produtos da fermentação + partículas não ou pouco fermentadas) e a regurgitação de material a ser remastigado. A atividade muscular do rúmen do recém-nascido é pequena, não sendo observadas contrações ou regurgitação. Quando alimento sólido é 
fornecido, contrações podem ser observadas em animais com 3 semanas de vida, e o hábito de remastigar, com apenas 1 semana (Van Soest, 1994).

Muitos trabalhos têm mostrado que o desenvolvimento de papilas, responsável pela absorção de produtos finais de fermentação, é dependente principalmente da presença de alimentos sólidos no rúmen, e conseqüente produção de ácidos graxos voláteis resultantes de fermentação (Quigley et al., 1996 a). Desta forma, o adequado desenvolvimento de papilas é resultado da ação de produtos de fermentação ruminal, além de estímulo físico causado pelo alimento consumido. Resultados de pesquisa indicam que o principal estímulo para o desenvolvimento do rúmen é a presença de ácidos graxos voláteis (Tamate et al., 1962; Murdock \& Wallenius, 1980; Quigley et al., 1996 a). Dentre os principais AGV produzidos no rúmen, o ácido butírico é o mais importante em relação ao crescimento em número e tamanho de papilas, seguido pelo ácido propiônico; tendo o ácido acético pouca importância.

Weigand et al. (1972) demonstraram que a taxa de absorção dos principais ácidos graxos ocorre na ordem butirato>propionato>acetato, em condições de $\mathrm{pH}$ entre 4,8 e 6,0, se igualando com pH 7,2. Entretanto, como explicou Bergman (1990), as quantidades transportadas no sangue estão na ordem reversa, ou seja, acetato>propionato>butirato. Isto demonstra que a ordem de importância dos AGV para o desenvolvimento do rúmen é a mesma com que estes ácidos são metabolisados pelo epitélio ruminal (Van Soest, 1994). A maior produção desses ácidos graxos voláteis ocorre com a fermentação de alimentos concentrados, com alto teor de carboidratos e proteína. Assim, a disponibilidade de concentrado para o animal desde a primeira semana de vida é indispensável (Anderson et al., 1987).

Já no início da década de 50 pesquisadores da Universidade de Cornell demonstraram a importância da dieta sólida para o desenvolvimento do rúmen quando observaram a regressão do desenvolvimento ruminal substituindo o fornecimento de dieta de grão e feno por leite em bezerros jovens já desmamados (Harrison et al., 1957). Mudanças neste compartimento são dinâmicas e altamente 
dependentes do tipo de dieta do animal. A troca de dieta composta principalmente de concentrado para aquela de forragem reduz o desenvolvimento papilar, epitelial e muscular. Adicionalmente, a completa retirada de alimento sólido leva ao total desaparecimento de papilas ruminais, regressão do tecido do compartimento ruminal e ausência de crescimento do mesmo. $O$ crescimento de papilas ruminais foi mínimo em bezerros alimentados somente a base de leite, o qual não sofre fermentação ruminal, quando comparados com animais alimentados com alimento concentrado ou feno (Tamate et al., 1962).

Beharka e colaboradores (1998) demonstraram o efeito da forma física da dieta no desenvolvimento anatômico, microbiano e fermentativo do rúmen de bezerros recém-nascidos. Oito bezerros holandeses foram canulados no rúmen aos 3 dias de vida sendo alimentados com dieta moída ou não, composta de $25 \%$ de feno de alfafa e $75 \%$ de concentrado. Animais alimentados com a dieta não moída apresentaram menor consumo. $\mathrm{O}$ pH ruminal decresceu após 2 semanas de vida e voltou a aumentar após a $10^{\text {a }}$ semana, sendo influenciado pela forma física da dieta. $\mathrm{O} \mathrm{pH}$ ruminal foi menor $(\mathrm{P}<0,01)$ para bezerros recebendo dieta moída na $4^{\text {a }}$ e $6^{\text {a }}$ semana de vida. A concentração total de AGV aumentou de forma significativa com a idade animal e apenas tendeu $(P=0,12)$ a ser superior para bezerros alimentados com dieta moída. Assim sendo, os menores níveis de $\mathrm{pH}$ ruminal destes animais não podem ser atribuídos às maiores concentrações de ácidos graxos. Os autores especulam que provavelmente animais recebendo dieta não moída apresentaram o epitélio ruminal mais desenvolvido e capaz de absorver maiores quantidades de AGV. A concentração de $\mathrm{NH}_{3} \mathrm{~N}$ reduziu com a idade animal indicando aumento na atividade microbiana neste compartimento e consequentemente utilização desta fração, ou aumento na absorção na parede ruminal. Bezerros recebendo dieta moída apresentaram população numericamente maior de bactérias anaeróbia, indicando um maior desenvolvimento ruminal. Estes animais apresentaram também menor contagem de bactérias celulolíticas e maior de amilolíticas que bezerros alimentados com dieta não moída. Apesar de algumas 
alterações no padrão de fermentação, a forma física da dieta não alterou o peso cheio e vazio do retículo-rúmen e abomaso dos animais. Entretanto, bezerros alimentados com dieta moída apresentaram maior peso cheio e vazio do omaso, provavelmente como consequência de maior passagem de partículas do rúmen para este compartimento.

Durante muito tempo acreditou-se que o fornecimento de feno ao bezerro em aleitamento fosse indispensável, devido ao estímulo físico para o desenvolvimento de papilas. Contudo, quando material inerte ou esponjas foram fornecidos à pré-ruminantes, observou-se que somente o estímulo físico não é suficiente para um desenvolvimento adequado. O fornecimento deste tipo de material não resulta no início do desenvolvimento epitelial e sim na expansão e crescimento muscular e capacidade do rúmen (Huber, 1969). O fornecimento de forragem é importante para o crescimento da camada muscular do rúmen e para manutenção de epitélio ruminal saudável, capaz de absorver AGV, mas não estimula o desenvolvimento de papilas (Lydorf Jr., 1988).

O consumo voluntário de feno é muito reduzido até aproximadamente 6 - 7 semanas de idade e, como a maior parte do feno disponível tem baixa energia para bezerros, se recomenda seu fornecimento somente após a desmama (Quigley, 1996b) ou a partir de $6^{\text {a }}$ ou $7^{\text {a }}$ semana caso a desmama seja tardia. Klein et al. (1987) demonstraram que a inclusão de feno na ração inicial de bezerros não afetou de forma positiva o desenvolvimento do rúmen ou o desempenho desses animais. Quigley et al. (1992a) observaram que o fornecimento de feno para bezerros, após a desmama com 8 semanas de vida, reduziu os níveis de corpos cetônicos (BHBA e ACAC), provavelmente pela redução na produção de ácido butírico no rúmen. Se o fornecimento de feno fosse realizado antes da desmama as custas do fornecimento de concentrado, acarretaria no atraso no desenvolvimento do rúmen graças à menor produção de butirato.

Em trabalhos recentes, et al. (2001a e b) demonstraram que a menor degradabilidade de proteína, resultando em menores níveis de amônia ruminal, 
resultaram em menor desenvolvimento de papilas rumais. Os animais recebendo dieta com proteína de menor degradabilidade (farinha de penas) apresentaram papilas menores, em menor número e com menor área de absorção.

Conforme o rúmen se desenvolve ocorre uma mudança no tipo de nutriente disponível para o bezerro. Ao nascer, o animal tem o abomaso como o principal órgão digestivo, sendo a glicose e a proteína da dieta sua fonte energética e protéica, respectivamente. Durante a fase de transição não-ruminante/ruminante, o rúmen começa a participar como órgão digestivo, produzindo AGVs e proteína microbiana que, juntamente com a glicose e a proteína da dieta compõem as fontes de energia e proteína para o animal. Com o total desenvolvimento do rúmen, este passa a ser o principal órgão digestivo sendo os AGV e a pouca glicose produzida no intestino as fontes energéticas; enquanto que as fonte de protéicas são a proteína microbiana e a proteína dietária não degradável no rúmen, além da proteína endógena.

Com a passagem gradativa do animal de não ruminante para ruminante a concentração de glicose no sangue diminui enquanto as concentrações de AGV, acetato e $\beta$-hidroxibutirato (BHBA) aumentam. O butirato é metabolizado à corpos cetônicos pelo epitélio ruminal e pelo fígado, sendo estes liberados na circulação e usados como fonte de energia por tecidos periféricos. A conversão de butirato para BHBA é afetada pelo pH e pela concentração de AGV no rúmen; e negativamente correlacionada com a taxa de absorção de butirato (Weigand et al.,1972).

O aumento na concentração de BHBA está fortemente correlacionado com a disponibilidade de concentrado para bezerros, como observaram Quigley et al. (1991 a). Estes autores demonstraram que a concentração deste metabólito no sangue pouco antes da desmama, refletiu a produção de acetato e butirato no rúmen. Em outro trabalho, Quigley \& Bernard (1992) estudaram o efeito "tempo" na concentração desses metabólitos no sangue de bezerros. Parâmetros sangüíneos foram fortemente influenciados pelo tempo após o fornecimento da mistura de concentrado. As mudanças foram associadas a rápida fermentação de 
carboidratos solúveis. O fornecimento de feno, ad libitum após a desmama, reduziu indiretamente a concentração sanguínea de corpos cetônicos devido à redução na produção de butirato no rúmen.

Alguns autores têm associado altos níveis plasmáticos de BHBA com supressão do sistema imune de bezerros (Targowski \& Klucinski, 1983; Targowski et al., 1985). Entretanto, Nonnecke et al. (1992) demonstraram que a secreção de IgM não foi afetada com níveis de BHBA tão altos quanto 6,25 mM.

Quigley et al. (1994) avaliaram em bezerros desmamados com 35 e 49 dias, o efeito dos níveis de BHBA na resposta mitogênica de células brancas. Os autores não observaram redução na resposta mitogênica de células brancas, concluindo que as práticas de manejo visando desenvolvimento ruminal e conseqüente produção de BHBA não têm efeito supressor no sistema imune.

Quando práticas convencionais de alimentação são adotadas, com aproximadamente 30 dias de idade, o epitélio ruminal de bezerros é capaz de metabolisar AGV numa taxa de aproximadamente $40 \%$ daquela de um ruminante adulto (Bush, 1988). A observação de maior desenvolvimento (número e tamanho) de papilas ruminais com a realização de infusões ruminais de sais de ácidos graxos voláteis sugeriu um efeito mitogênico dos AGV sobre células do tecido epitelial ruminal. Essa suposição tem estimulado a condução de pesquisas com células epiteliais do rúmen (CER) em cultura com diferentes AGV em concentrações (Gálfi et al., 1991).

Visto que as CER podem converter AGV a cetonas (BHBA e acetoacetato), o possível impacto desses compostos sobre mitose foi avaliado (Gálfi et al., 1991). Propionato e butirato tiveram efeito inibidor na síntese de DNA sendo este efeito dependente da concentração desses AGV; enquanto que acetato e acetoacetato praticamente não influenciaram o processo mitótico. Butirato inibiu não somente a síntese de DNA, mas também todo o processo mitótico de CER, como demonstraram as menores contagens de células. Esses resultados contradizem resultados in vivo, onde a infusão ruminal de butirato (Sakata \& Tamate, 1978) e 
propionato (Sakata \& Tamate, 1979) promoveu maior proliferação de células epiteliais.

Trabalhos de Van Wijk et al. (1981), citados por Gálfi et al. (1991), demostraram que as células diferem com relação ao nível extracelular de butirato necessário para que a inibição mitótica ocorra, mas que a concentração intracelular não apresenta muita variação. Esses resultados sugerem que a sensibilidade ao butirato depende principalmente da composição da membrana celular. Entretanto, células em contato freqüente com butirato, como é o caso de CER e células epiteliais intestinais (CEI), apresentam como mecanismo de proteção, a conversão de butirato à corpos cetônicos, os quais tem menor efeito em mitose (Gálfi, 1991). A contradição entre resultados in vitro e in vivo sugeriu a ação de um mecanismo mensageiro (hormônio, neurotransmissor, fator de crescimento) capaz de mediar, transformar ou compensar o efeito de butirato in vivo. Trabalhos mostram que o ácido butírico estimula a liberação de insulina enquanto que o ácido acético e o propiônico têm menor efeito.

Jordan e Phillips (1978) observaram que a liberação de insulina por células pancreáticas aumentou linearmente com a concentração de butirato adicionada à cultura, sendo esta resposta maior do que aquela provocada pela adição de glicose no meio de cultura. Os efeitos da adição de lactato, acetato, propionato e $\beta$ HBA não foram diferentes daquele do controle. O efeito de butirato deve estar relacionado com alterações nos níveis de cAMP que, geralmente, levam à secreção de insulina.

Insulina é um dos fatores essenciais para proliferação de células in vitro e, portanto, deve ser o mediador da proliferação estimulada por AGVs in vivo (Sakata et al., 1980). Insulina, insulina + glicose, glicose ou solução fisiológica foram administradas via jugular de carneiros fistulados, com o objetivo de determinar o efeito estimulador de insulina na proliferação de CER (Sakata \& Tamate, 1978). Papilas ruminais foram coletadas após infusão e o índice mitótico determinado. Os resultados mostram que quanto maior a concentração de insulina no sangue após 
a infusão, maior o índice mitótico apresentado. O aumento neste índice, após a infusão de insulina + glicose foi comparável àquele estimulado pela infusão intraruminal de butirato de sódio. Com base nestes dados, os autores concluíram que esta infusão no sangue simulou o nível de insulina após a infusão de butirato de sódio no rúmen e que, portanto, este hormônio deve, pelo menos parcialmente, mediar o estímulo mitótico de AGV in vivo.

Concluindo, o desenvolvimento ruminal é dependente do consumo de alimento sólido com alta concentração de carboidratos fermentescíveis que resultem na produção de ácidos graxos voláteis. A produção de AGV deve então disparar a proliferação de células epiteliais ruminais, processo este que também dependente de ação hormonal.

\subsection{Processamento de Grãos}

O termo processamento de grãos refere-se a métodos de preparação de grãos para alimentação animal. A floculação, a reconstituição e tostagem são métodos intensivos de processamento; enquanto que a laminação, moagem grosseira ou quebra do grão são formas menos intensas de processamento. (Theurer, 1986). O processamento de grãos está associado com melhor eficiência de utilização de nutrientes tanto em animais direcionados para a produção de carne (Huntington, 1997) quanto para a produção de leite (Theurer et al., 1999).

Os métodos de processamento podem ser divididos como processos físicos no caso da moagem, rolagem e peletização; e processos físico-químicos como a floculação e a laminação (Nocek et al., 1991). No processo de laminação a vapor durante curto período de tempo (1-8 min) o grão é exposto ao vapor sendo comprimido e quebrado durante sua passagem através de dois rolos de superfície sulcada. Não existe vantagem em digestibilidade quando se compara a laminação a vapor com o processo de moagem. Entretanto, segundo Simas (1996), pode ocorrer aumento na palatabilidade do grão, o que é um benefício em situações 
onde se almeja o aumento no consumo de alimento, como no caso de bezerros em aleitamento. No processo de floculação a umidade do grão é elevada à 18-20\% através de exposição ao vapor de água durante 30-60 minutos, para posterior passagem através de rolos com distância pré-determinada, para a produção de floculo de densidade determinada.

O principal efeito do processamento de grãos é a mudança no sítio de digestão de amido do intestino delgado para o rúmen, com concomitante aumento nas porcentagens degradadas em ambos compartimentos. Segundo Theurer (1986), o processamento de grãos minimiza as limitações intestinais à digestão de amido, aumentando a digestibilidade destes no pós-rúmen. A digestão de amido ocorrendo preferencialmente no rúmen resulta em um duplo benefício. Primeiro, ocorre maior produção de AGV e proteína microbiana do rúmen; segundo, o amido que chega ao intestino tem maior digestibilidade quando o grão de cereal é processado intensamente. O resultado final é um maior suprimento de energia e de proteína metabolizável para o animal (Huntington, 1997)

Um sumário de vários estudos in vitro mostra que o aumento de carboidratos não estruturais na dieta aumenta a produção de ácidos graxos voláteis, a síntese de proteína microbiana e reduz a concentração ruminal de amônia (Hoover \& Stokes, 1991).

A digestão do amido ocorrendo principalmente no rúmen resulta em maiores produções de ácidos graxos voláteis, principalmente propionato, o principal precursor de glicose através de gluconeogênese. Resultados obtidos em experimentos com vacas em lactação mostram maior produção total de AGV, principalmente propionato (Moore et al., 1992), e maior síntese de proteína microbiana (Santos et al., 1998). A floculação do grão de sorgo leva a aumentos de até $20 \%$ na concentração de propionato no total de AGV produzido (Moore et al., 1992; Oliveira et al., 1993; Chen, 1994). O aumento na produção de AGV e proteína microbiana no rúmen juntamente com o decréscimo na glicose disponível no intestino, altera os produtos finais da digestão, os quais são absorvidos pelo 
rúmen e pelo intestino, tendo impacto na distribuição de nutrientes para o resto do organismo do animal (Reynolds et al., 1994).

A digestão de amido no intestino delgado resulta em produção de glicose, a qual é utilizada basicamente para manutenção das vísceras do animal. Na maior parte dos trabalhos se observa um fluxo negativo de glicose chegando ao fígado, uma vez que a utilização desta pelo intestino e outros órgãos viscerais é superior a sua produção (alta taxa metabólica). O fornecimento de grãos processados intensamente gera maior produção de compostos gluconeogênicos devido a maior produção de propionato e proteína microbiana (Theurer et al., 1999). Quando se compara sorgo ou milho floculado com laminado a seco há um incremento de até $20 \%$ na $E L_{\text {I }}$ (Theurer et al., 1999). A floculação aumentou em 5-6\% a produção de leite, ou $1 \mathrm{~kg} / \mathrm{d}$ de leite corrigido para gordura, em relação à laminação a vapor.

A floculação do milho ou sorgo também altera a composição do leite com um aumento na \% de proteína do leite de 0,07 unidade percentual e consequente aumento na produção de proteína do leite $(8 \%)$.. A alta disponibilidade de carboidratos, ou energia, permite uma maior, ou melhor, utilização de proteína no rúmen, além de estimular a reciclagem de amônia para dentro do sistema, resultando em maior produção de proteína microbiana e maior fluxo desta para o intestino. Devido a alta qualidade desta proteína em termos de aminoácidos essenciais, observa-se um aumento na \% de proteína do leite. (Theurer et al., 1999).

A adição de grão floculado nas dietas de animais de corte em crescimento ou engorda, tem mostrado consistente aumento na eficiência alimentar através da maior utilização de amido quando comparado ao grão não processado ou laminado (Theurer et al., 1996a e b).

Dados de desempenho de bezerros em aleitamento, recebendo grãos processados na mistura concentrada são restritos. Schuh et al. (1970) foram os primeiros a testar grãos floculados ou laminados para bezerros em aleitamento. A performance dos animais assim como o consumo de concentrado não foi diferente, 
mas houve tendência de melhor conversão alimentar em animais recebendo grão floculado. Em dois trabalhos subsequentes Schuh et al. (1970 b) compararam o sorgo grão floculado com o grão cozido à pressão de vapor para bezerros recebendo feno de alfafa ou pelete do mesmo material ad libitum até 90 dias de vida; sendo que no segundo experimento os animais foram agrupados por tratamento após os 40 dias de vida. Em ambos os experimentos, o ganho de peso e o consumo de MS foram maiores nos animais recebendo grãos floculados. A eficiência alimentar não diferiu entre grãos floculados ou laminados.

Daniels et al. (1972) testaram a adição de grãos processados no concentrado de bezerros antes e após a desmama. O processamento de sorgo juntamente com farelo ou com o grão de soja não resultou em maiores ganhos de peso ou consumo de matéria seca quando comparado com o grão de sorgo peletizado. $O$ efeito do processamento também foi pequeno com relação a digestibilidade de proteína ou energia do concentrado.

A forma física do concentrado é um dos fatores que afetam seu consumo por bezerros. Alimentos finamente moídos resultam em menor consumo além de poderem causar paraqueratose ruminal, reduzindo a capacidade absortiva das papilas ruminais. Este é o principal fator limitante do uso de concentrados peletizados para bezerros, uma vez que o processo de peletização requer a moagem fina dos ingredientes (Davis \& Drackley, 1998). Vários trabalhos mostraram que o tamanho da partícula do alimento, principalmente da fração fibra, é mais crítico do que a concentração de fibra propriamente dita no concentrado.

Warner et al. (1991) recomendam que pelo menos $50 \%$ das partículas devam ser maiores que 1,2 mm. Este estudo comparou 2 concentrados com o mesmo nível de FDN mas com diferentes tamanhos de partícula da fração fibra (farelado vs. peletizado). O maior tamanho de partícula aumentou o consumo de concentrado, o ganho de peso, e desenvolvimento do rúmen.

Comparando concentrado peletizado, que requer a moagem fina, com o fornecimento de grãos inteiros de cevada para bezerros de 10 dias de idade, 
Economides et al. (1990) não observaram diferenças entre tratamentos. Entretanto, devido a alta digestibilidade do amido da cevada, este cereal é menos responsivo ao processamento que cereais como o milho e o sorgo. Apesar disso, trabalhos têm demonstrado que para animais em lactação um mínimo de processamento de grãos de cevada, como uma moagem grosseira, é necessário (NRC, 2001).

Abdelgadir \& Morril (1995) realizaram vários trabalhos com o processo de conglomeração, o qual consiste na moagem dos grãos de sorgo, adição de água para a formação de peletes e posterior tostagem. Os bezerros receberam concentrado contendo sorgo moído, tostado ou conglomerado. A desmama foi realizada com base no consumo de concentrado, contanto que o animal tivesse mais que 3 semanas de vida e pesasse $4,5 \mathrm{~kg}$ a mais do peso ao nascer. $O$ tipo de processamento não afetou o ganho de peso, as medidas corporais ou a idade a desmama dos animais. Entretanto, o consumo total foi inferior para animais recebendo sorgo conglomerado. $\mathrm{O}$ tipo de processamento não afetou parâmetros sanguíneos ou ruminais, mas os valores de $\mathrm{pH}$ foram superiores para animais alimentados com sorgo conglomerado. Excetuando-se o menor consumo de concentrado apresentado por animais recebendo grão conglomerado, todos os resultados foram confirmados em experimento subseqüente onde comparou apenas a tostagem e a conglomeração.

Comparando 3 diferentes densidades de milho floculado em dietas para bezerros leiteiros, Bagaldo et al. (2001) observaram que as densidades de 283 , 360 e $437 \mathrm{~g} / \mathrm{L}$ não afetaram o consumo de concentrado ou de matéria seca total, assim como o ganho de peso ou número de dias a desmama para bezerros na fase de aleitamento. Em trabalho subsequente, avaliando desempenho de bezerros da desmama aos 120 dias, estes autores também não observaram efeito de diferentes densidades de processamento de milho no desempenho de bezerros. Entretanto, segundo Barmore (1994), a densidade do grão processado está relacionada a sua palatabilidade e consequentemente aceitação pelo bezerro. 
Embora a melhor densidade de grão floculado esteja determinada para vacas em lactação $(360 \mathrm{~g} / \mathrm{L})$ (Theurer, 1992) e para animais de corte em confinamento (280g/L) (Alio et al., 2001), este valor ainda não está estabelecido para bezerros em aleitamento ou após a desmama. Maior número de dados de performance e de parâmetros ruminais de bezerros em aleitamento são necessários.

\subsection{Monensina}

Ionóforos são compostos que alteram o transporte de cátions através de membranas celulares e que, quando administrados a ruminantes, alteram o padrão de fermentação ruminal devido à seleção de determinadas populações de bactérias no rúmen (Bergen \& Bates, 1984). Os benefícios desta ação podem ser classificados em três áreas: 1) aumento na eficiência do metabolismo energético de bactérias ruminais e/ou do animal; 2) melhor metabolismo de $\mathrm{N}$ por bactérias e/ou animais; e 3) menor ou tardio aparecimento de desordens digestivas resultantes de fermentação ruminal anormal.

Trabalhos têm demonstrado que esta seleção de bactérias leva à maior produção de ácido propiônico e menor produção de ácidos láctico, acético e butírico. A menor produção de ácido butírico poderia ser um fator limitante para a adição de ionóforos na dieta de bezerros jovens. Entretanto, não se encontra na literatura trabalhos relacionando a administração de ionóforos com desenvolvimento ruminal. Por outro lado, dados de desempenho mostram que a adição desses em dietas para bezerros tem sido benéfica, muitas vezes permitindo adiantar a desmama.

O transporte de íons se inicia à medida que o ionóforo, na sua forma aniônica, é estabilizado pela polaridade característica da superfície de membranas. A ligação a um cátion resulta na formação de um complexo lipofílico cátionionóforo que é capaz de atravessar a estrutura de membranas. Dentro da célula, o 
ionóforo libera o cátion e se liga a um hidrogênio, o qual é transportado para fora da célula (Bergen \& Bates, 1984). Esse processo causa total consumo de ATP intracelular. Diferenças na estrutura da parede celular entre bactérias gram-positiva e gram-negativas estão envolvidas no processo seletivo que ocorre no rúmen. A membrana em forma de envelope presente em bactérias gram-negativas funciona como uma barreira aos ionóforos que são impossibilitados de dissipar o gradiente de prótons através da membrana celular. Adicionalmente, bactérias gramnegativas possuem uma enzima (fumarato reductase) que converte fumarato a succinato via um sistema redox que é capaz de criar uma força motivada pelo gradiente de prótons e, consequentemente produzir ATP (Russel, 1987). Assim, bactérias gram-negativas são mais resistentes a ação de ionóforos e acabam sendo selecionadas (Dennis et al., 1981; Bergen \& Bates, 1984).

Vários estudos mostram que a ação de ionóforos se dá através da seleção de determinada população de bactérias que levam à mudanças no processo de fermentação ruminal (Dennis et al., 1981; Nagaraja et al., 1981; Bergen \& Bates, 1984; Russel, 1987). A seleção de bactérias gram-negativas resulta em maior produção de propionato mas, menor produção de lactato, acetato e butirato. A administração de lasalocida e monensina, produtos mais usados na industria animal, está associada a aumentos na produção de propionato, e decréscimos em acetato, butirato e metano (Thornton \& Owens, 1981; Sauer et al., 1989; Spears, 1990). Decréscimos na deaminação ruminal de aminoácidos (Whetstone et al., 1981) assim como redução na taxa de passagem (Van Nevel \& Demeyer, 1988; Spears, 1990) também foram demonstrados. Como resultado dessas mudanças na fermentação ruminal, estudos mostram melhoria na performance de bovinos de corte (Goodrichs et al., 1984; Bergen \& Bates, 1984; Spears, 1990) e em bovinos leiteiros (Sauer, 1989).

O aumento na produção de propionato e de sua utilização para gluconeogênese pode resultar na economia de amino ácidos e na redução da mobilização de tecido adiposo e produção de corpos cetônicos no fígado. Vários 
trabalhos têm sinalizado o aumento nas concentrações de glicose plasmática, redução na concentração de BHBA e de AGL com o fornecimento de monensina (Sauer et al., 1989; Phipps et al., 1997; Duffield et al., 1998). Além disso, os ionóforos previnem a ocorrência de acidose subclínica reduzindo a formação de lactato e estabilizando o $\mathrm{pH}$ ruminal.

O maior benefício da administração de monensina para bezerros em aleitamento, além do controle de coccidiose, é o aumento na produção de propionato, apesar da redução de butirato, principal estimulador do desenvolvimento ruminal. Segundo trabalhos citados na revisão de McGuffey et al. (2001), o aumento na produção de propionato é explicado pela reposição de bactérias gram-positivas por bactéria gram-negativas, além de alterações mediadas pelo ionóforo no metabolismo de gram-negativas. Trabalhos utilizando a técnica de isótopos marcados demonstraram aumentos de 49 e $76 \%$ na taxa de produção de propionato em novilhos recebendo rações com alta forragem e alto concentrado, respectivamente (Van Maanan et al., 1978, citados por McGuffey et al., 2001).

Alguns trabalhos sinalizam mudanças no sítio de digestão das diferentes frações de carboidratos com o fornecimento de ionóforos. Funk et al. (1986) e Muntifering et al. (1981) observaram a redução da digestão de amido no rúmen e aumento no pós-rúmen, sem afetar a digestão de amido no trato total. Muntifering et al. (1981) utilizaram dieta com $61,7 \%$ de amido na MS, composta de $90 \%$ de grão de milho inteiro e observaram redução de $19 \%$ na digestibilidade de amido $(61,1$ vs. 49,5$)$ no rúmen de novilhos com o fornecimento de monensina. Funk et al. (1986) também observaram reduções da ordem de 19\% na digestibilidade de amido quando lasalocida foi incluída na dieta de ovinos composta de $56 \%$ de milho e $35 \%$ de feno de alfafa. Este efeito não é desejável para sistemas que visam rápido desenvolvimento do rúmen de bezerros, entretanto pode garantir bom desempenho destes animais na fase de transição não-ruminante/ruminante uma vez que o amido tem alta digestão no intestino. 
Com relação a bovinos leiteiros em crescimento, a maior parte dos trabalhos utilizou ionóforos como coccidiostáticos, principalmente para bezerras até 20 semanas de vida. Em bovinos, Eimeria bovis e E. zuernii são os causadores de coccidiose, que ocorre quando condições do meio e de manejo, tais como superpopulação e sanidade da água e da dieta, levam à ingestão de oocistos. Adicionalmente, a resistência a doenças, a nutrição e o estado nutricional são fatores que podem precipitar o aparecimento de coccidiose. Assim, o adequado manejo de bezerros é essencial para evitar a doença. O primeiro sinal de coccidiose é diarréia crônica mal cheirosa, sendo que as fezes fluidas podem conter sangue e/ou muco. Esses sinais são geralmente acompanhados por desidratação do animal. Decréscimos no consumo de matéria seca também são observados em bezerros infectados, resultando em menores ganhos de peso (Georgi, 1985).

Alguns ionóforos têm a habilidade de controlar coccidiose através do transporte de cátions para dentro do oocisto. Devido a alta concentração de cátions dentro da célula, ocorre entrada de água por osmose, o que leva ao rompimento do oocisto. Monensina e lasalocida são eficazes no controle de coccidia como mostram inúmeros trabalhos (Fitzgerald e Mansfield, 1973; McDougald, 1978; Stockdale et al., 1982; Stromberg et al., 1986; Watkins et al., 1987; Hoblet, 1989; Heinrichs et al., 1994; Quigley, 1996 a). Dados de performance foram gerados desses experimentos, mas poucos dados existem referentes a mudanças no padrão de fermentação de bezerras leiteiras.

Embora a doença seja sempre controlada com eficácia, dados de performance de bezerros leiteiros recebendo ionóforos para controle de coccidiose mostram inconsistência. Stockdale et al. (1982) estudaram o desenvolvimento de resistência a Eimeria em bezerros controle ou recebendo amprolium (10 $\mathrm{mg} / \mathrm{kg} \mathrm{PV}$ ) ou monensina ( $1 \mathrm{mg} / \mathrm{kg}$ PV) e não observaram diferenças no ganho de peso diário dos animais. Foreyt et al. (1986) observaram desempenho similar de bezerros tratados com monensina, lasalocida e decoquinato, um coccidiostático não 
promotor de crescimento, após inoculação com Eimeria. Outros estudos conduzidos com o fornecimento da dose mais efetiva de lasalocida para o controle de coccidiose (1 $\mathrm{mg} / \mathrm{kg} \mathrm{PV}$ ), para animais de diferentes idades, também mostram que a administração do ionóforo não afetou o desempenho de bezerros leiteiros (Stromberg et al., 1982; Hoblet et al., 1989; Heinrichs \& Bush, 1991; Waggoner et al., 1994). Por outro lado, em alguns trabalhos observou-se melhor desempenho de bezerros recebendo monensina (Fitzgerald \& Mansfield, 1973 e 1984; Watkins et al., 1987) ou lasalocida (Sinks et al., 1992; Quigley, 1996 a). Provavelmente parte da variação nos resultados obtidos se deve a diferentes idades dos animais e ao fato de que animais jovens talvez não utilizem ionóforos como animais adultos o fazem. Entretanto, alguns dos trabalhos citados foram conduzidos com animais em aleitamento.

A redução no consumo de matéria seca resultante do fornecimento de ionóforos para animais em confinamento está ligada à redução nas taxas de passagem das frações liquida e/ou sólida do rúmen dependendo dos níveis utilizados (Van Nevel \& Demeyer, 1988). Alguns trabalhos mostram redução no consumo de matéria seca de animais em crescimento recebendo monensina (Fitzgerald et al., 1984; Goodrichs et al., 1984; Gaylean \& Hubbert, 1989; Nussio, 1997). Anderson et al. (1988) observaram que o aumento no consumo de matéria seca de bezerros recebendo lasalocida ocorreu somente após a desmama. Entretanto, em alguns trabalhos, lasalocida ou monensina, não afetaram o consumo de matéria seca (Foreyt et al., 1986; Quigley et al. 1992 b; Nussio, 1997). A redução no consumo de matéria seca pode acarretar num desenvolvimento mais retardado do rúmen de bezerros já que esse processo é dependente da produção de ácidos graxos voláteis, principalmente butirato. Adicionalmente, a desmama de bezerros também pode ser atrasada em manejos onde se faz a desmama de acordo com matéria seca consumida e não com dias de vida do animal. 


\title{
3 PROCESSAMENTO DE MILHO (FLOCULADO vs. LAMINADO A VAPOR) E SUPLEMENTAÇÃO DE MONENSINA PARA BEZERRAS LEITEIRAS, PRÉ E PÓS DESMAMA PRECOCE.
}

\author{
Autor: Carla Maris Bittar Nussio \\ Orientador: Prof. Dr. Flávio Augusto Portela Santos
}

\section{Resumo}

A suplementação de fontes de amido de maior digestibilidade e o uso de aditivos com atividade coccidiostática e promotora de crescimento, podem melhorar o desempenho de bezerros leiteiros pré e pós desmama. O objetivo deste trabalho foi o de avaliar o efeito de concentrados contendo milho laminado a vapor ou floculado, com ou sem a adição de monensina, no consumo, ganho de peso e parâmetros sanguíneos de bezerras leiteiras, antes e após a desmama realizada a sexta semana de vida. Foram utilizadas 32 bezerras holandesas do nascimento a 12 semanas de vida, em um delineamento experimental do tipo blocos ao acaso, com arranjo fatorial $2 \times 2$. Do nascimento a desmama os animais receberam concentrado ad libitum até o consumo de $2 \mathrm{~kg} / \mathrm{d}$, quatro litros diários de leite e tiveram acesso livre à água. Após a desmama, realizada na sexta semana de vida, os animais continuaram recebendo $2 \mathrm{~kg}$ de concentrado e passaram a ter acesso a feno picado ad libitum. $O$ tipo de processamento de grão ou a adição de monensina não afetou o consumo médio de concentrado ou feno $(P>0,05)$, assim como o peso final e o ganho de peso diário $(P>0,05)$. As concentrações plasmáticas de glicose e AGL médios do período experimental não foram afetadas 
pelos tratamentos; entretanto, as concentrações de $\mathrm{N}$-uréico foram inferiores no plasma de animais recebendo concentrado com grãos laminados e monensina $(P=0,08)$. Houve efeito significativo da idade animal nas concentrações plasmáticas de glicose $(P<0,0001)$, N-uréico $(P<0,001)$ e $A G L(P<0,02)$. Somente os parâmetros glicose e AGL plasmáticos foram afetados pelo horário após 0 fornecimento do alimento.

\section{Corn processing (steam-flaked vs. steam-rolled) and monensin supplementation for pre and post early-weaning dairy calves.}

\section{Summary}

The supplementation of more digestible starch sources and feed additives with coccidiostatic and growth promoting activities may improve pre and post weaning calves performance. The objective of this trial was to evaluate the effects of concentrates containing processed grains (steam-flaked vs. steam-rolled), with or without monensin, on intake, weight gain and blood parameters of baby calves, before and after weaning at six weeks of life. Thirty-two baby heifers were utilized on a completely randomized block, with a $2 \times 2$ factorial arrangement. The animals received concentrate ad libitum up to $2 \mathrm{~kg} / \mathrm{d}$, plus $4 \mathrm{~L}$ of milk. Calves had free access to water. After weaning, at the sixth week of life, calves received concentrate and chopped hay. The treatments did not affect $(P>0,05)$ cocentrate or hay intake, final live weight, average daily gain, plasma glucose and NEFA cocentration. PUN was lower on calves fed steam-rolled corn and monensin $(P=0,08)$. There was a significant effect of age on glucose $(P<0,0001)$, PUN $(P<0,001)$, and NEFA $(P<0,02)$ concentrations. Only glucose and NEFA were affected by time after feeding. 


\subsection{Introdução}

A alta mortalidade de bezerros nos primeiros dias de vida devido à diarréia tem levado à administração de coccidiostáticos para animais em crescimento, visto que coccidia é um dos agentes causadores de diarréia que pode levar à morte. Alguns dos coccidiostáticos utilizados na criação de bezerras, como lasalocida e monensina, são também ionóforos, produtos que otimizam o desempenho de animais em crescimento.

lonóforos atuam no rúmen selecionando bactérias com maior produção de propionato, mas menor produção de lactato, acetato e butirato (Bergen \& Bates, 1984). A adição de monensina em dietas de animais em confinamento tem efeito benéfico comprovado por inúmeros trabalhos (Goodrich et al., 1984). O maior benefício da administração de monensina para bezerras em aleitamento, além do

controle de coccidiose, é o aumento na produção de propionato, apesar da redução de butirato, principal estimulador do desenvolvimento ruminal. Entretanto, a redução no consumo de matéria seca geralmente observada seria uma das desvantagens de sua inclusão na dieta de animais em aleitamento, uma vez que poderia atrasar a desmama em sistemas onde se adota o consumo de concentrado como critério para desmama.

Os resultados de desempenho obtidos com o fornecimento de ionóforos, como a monensina e a lasalocida, para bezerras leiteiras mostram inconsistência. Stockdale et al. (1982) não observaram diferenças no ganho de peso diário compararam o concentrado controle com o concentrado contendo monensina ou amprolium. Da mesma forma, Foreyt et al. (1986) observaram desempenho similar de bezerros tratados com monensina, lasalocida e decoquinato, um coccidiostático não promotor de crescimento, após inoculação com Eimeria. Outros estudos conduzidos com o fornecimento de lasalocida para o controle de coccidiose, para animais de diferentes idades, também mostram que a administração do ionóforo não afetou o desempenho de bezerros leiteiros (Stromberg et al., 1982; Hoblet et 
al., 1989; Heinrichs \& Bush, 1991; Waggoner et al., 1994). Por outro lado, em alguns trabalhos observou-se melhor desempenho de bezerros recebendo monensina (Fitzgerald \& Mansfield, 1973 e 1984; Watkins et al., 1987) ou lasalocida (Sinks et al., 1992; Quigley, 1996 a). Provavelmente parte da variação nos resultados obtidos se deve a diferentes idades dos animais e ao fato de que animais jovens talvez não utilizem ionóforos como animais adultos o fazem.

O consumo de grãos processados, como floculado ou laminado, também altera o padrão de fermentação ruminal de forma benéfica ao animal, com maior produção de propionato e consequente maior produção de glicose por gluconeogênese (Theurer et al., 1999). A adição de grão floculado nas dietas de animais de corte em crescimento ou engorda, tem mostrado consistente aumento na eficiência alimentar através da maior utilização de amido quando comparado ao grão não processado ou laminado (Theurer et al., 1996 a).

Dados de desempenho de bezerros em aleitamento recebendo grão processado na mistura concentrada são restritos. Schuh et al. (1970) e Daniels et al. (1972) não observaram efeitos positivos no desempenho ou consumo de concentrado com a inclusão de grãos processados no concentrado de bezerros. Em trabalho subsequente, Schuh et al. (1970 b) observaram maiores ganho de peso diários e consumo de MS em animais recebendo grão floculado. Abdelgadir \& Morrill (1995) compararam concentrado contendo sorgo não processado, tostado ou conglomerado para bezerros em aleitamento. O tipo de processamento não afetou o desempenho, as medidas corporais ou a idade a desmama dos animais. Entretanto, o consumo total foi inferior para animais recebendo sorgo conglomerado. O tipo de processamento também não afetou parâmetros sanguíneos ou ruminais, mas os valores de $\mathrm{pH}$ foram superiores para animais alimentados com sorgo conglomerado. Bagaldo et al. (2001) observaram que as densidades de 283, 360 e $437 \mathrm{~g} / \mathrm{L}$ não afetaram o consumo de concentrado ou de matéria seca total, assim como o ganho de peso ou número de dias a desmama para bezerros na fase de aleitamento. Em trabalho subsequente, avaliando 
desempenho de bezerros da desmama aos 120 dias, estes autores também não observaram efeito devido a diferentes densidades de processamento de milho. Embora a melhor densidade de grão floculado esteja determinada para vacas em lactação (360g/L) (Theurer, 1999) e para animais de corte em confinamento $(280 \mathrm{~g} / \mathrm{L})$ (Alio et al., 2001), este valor ainda não está estabelecido para bezerros em aleitamento ou após a desmama.

O efeito do processamento de grão e a adição de ionóforos pode levar a outro tipo de resposta quando fornecidos à animais com o rúmen em desenvolvimento, uma vez que alteram o padrão de fermentação ruminal. A adaptação do animal à fermentação ruminal é essencial para que sua taxa de crescimento não seja afetada pela desmama. Assim, o animal deve ter o rúmen desenvolvido e capaz de absorver e metabolisar produtos finais da fermentação antes da desmama. Maior número de dados de performance e de parâmetros sanguíneos e ruminais de bezerros em aleitamento são necessários.

O presente trabalho teve como objetivo avaliar a adição de grãos processados e monensina no concentrado de bezerras leiteiras, em relação ao desempenho e parâmetros sanguíneos, antes e após a desmama precoce.

\subsection{Material e métodos}

\subsubsection{Animais e Dietas Experimentais}

O experimento foi conduzido no Departamento de Produção Animal da Escola Superior de Agricultura "Luiz de Queiroz", da Universidade de São Paulo. Foram utilizadas 32 bezerras Holandesas em um delineamento experimental do tipo de blocos ao acaso, com um arranjo fatorial $2 \times 2$ (processamento de grãos e adição de monensina).

Após o nascimento, os animais foram separados da mãe, recebendo $2 \mathrm{~L}$ de colostro logo após o nascimento, e a cada 12 horas até o segundo dia de vida. 
Decorrido este período, os animais passaram a receber $4 \mathrm{~L}$ de leite por dia, divididos em duas refeições (07 e 18h), além de água à vontade e de um concentrado inicial. A mistura foi fornecida ad libitum diariamente, após a retirada da sobra do dia anterior, até que o consumo atingisse $2 \mathrm{~kg} / \mathrm{dia}$.

O concentrado, formulado para atender as exigências nutricionais de bezerros até 12 semanas de vida (NRC, 1986), era composto de $67,5 \%$ de milho floculado (F) ou milho laminado (L), 20\% de farelo de soja, 10\% de melaço e 2,5\% de premix de minerais e vitaminas com (LM ou FM) ou sem (L ou F) a adição de monensina (Tabela 1). A concentração de monensina no concentrado foi de 30 $\mathrm{ppm}$, ou $30 \mathrm{mg} / \mathrm{kg}$ de matéria seca, dose recomendada para o controle de coccidiose em bezerras leiteiras. $O$ fornecimento de feno de coast-cross passou a ser fornecido ad libitum, após a desmama dos animais, a qual ocorreu na $6^{a}$ semana de vida.

Tabela 1. Composição do concentrado experimental (\% MS).

\begin{tabular}{lcccc}
\hline Ingredientes & F & FM & L & LM \\
\cline { 2 - 5 } Milho floculado & 67,5 & 67,5 & -- & -- \\
Milho laminado & - & -- & 67,5 & 67,5 \\
Farelo de soja & 20,0 & 20,0 & 20,0 & 20,0 \\
Melaço & 10,0 & 10,0 & 10,0 & 10,0 \\
Premix1 (minerais, vitaminas, monensina) & 2,5 & -- & 2,5 & -- \\
Premix 2 (minerais, vitaminas) & -- & 2,5 & -- & 2,5 \\
\hline F= milho floculado, FM= milho floculado c/ monensina, L= milho laminado, LM= milho laminado cl \\
monensina
\end{tabular}

Os animais foram alocados em abrigos individuais, o que permitiu o monitoramento diário do consumo de concentrado e semanal do consumo de feno. As pesagens foram realizadas ao nascer e a cada semana até completarem 12 semanas de vida, quando se encerrou o período experimental. 


\subsubsection{Avaliação do alimento}

A floculação e a laminação foram realizadas pela empresa Sul Mineira S/A e objetivaram a produção de grãos com 480 e 360 g/L, respectivamente.

Para estimar o consumo de matéria seca (MS), amostras dos alimentos foram coletadas e secas à $105^{\circ} \mathrm{C}$, e o teor de MS determinado. Amostras de concentrado e feno fornecidos foram coletadas a cada nova batida, secas à $55^{\circ} \mathrm{Ce}$ moídas à $1 \mathrm{~mm}$ para determinação de $\mathrm{MS}$, matéria orgânica $(\mathrm{MO})$ e proteína bruta (PB) de acordo com AOAC (1980), fibra em detergente neutro (FDN) e fibra em detergente ácido (FDA) pelo método descrito por Van Soest (1991) e amido conforme descrito por Poore (1991).

\subsubsection{Procedimentos de Coleta e Métodos Analíticos}

3.2.3.1 Metodologia de coleta de sangue para determinação de glicose, $\mathrm{N}$-uréico e ácidos graxos livres

Amostras de sangue foram coletadas de 24 fêmeas através de punção da jugular com auxílio de tubos de ensaio a vácuo, contendo $5 \mathrm{mg}$ de fluoreto de sódio como antiglicolítico e $5 \mathrm{mg}$ de oxalato de potássio como anticoagulante para análise de glicose, $\mathrm{N}$-uréico e ácidos graxos livres. As amostragens de sangue foram realizadas a cada 7 dias de vida do animal nos horários $0,2,4,8$ e $12 \mathrm{~h}$ após a alimentação da manhã. As amostras foram centrifugadas a 3000 x g, por 20 minutos, a temperatura de $4{ }^{\circ} \mathrm{C}$ para obtenção do plasma, o qual foi armazenado em tubos de $2 \mathrm{~mL}$ do tipo "eppendorf" a $-10{ }^{\circ} \mathrm{C}$ para posterior análise.

3.2.3.2 Determinação de Glicose 
A determinação das concentrações de glicose plasmática foi realizada por leitura direta em autoanalisador YSI 2700 Select (Biochemistry Analyser, Yellow Spring, $\mathrm{OH}, \mathrm{EUA}$ ) no Laboratório de Bromatologia do Departamento de Produção Animal da ESALQ/USP. A leitura direta foi realizada com a utilização de membrana com a enzima glicose oxidase imobilizada. Uma solução de dextrose com concentração de $2 \mathrm{~g} / \mathrm{L}$ foi utilizada como calibrador interno e como solução para controle de qualidade.

\subsubsection{Determinação de N-uréico}

Para as determinações das concentrações de $\mathrm{N}$-uréico, realizadas no Laboratório de Bromatologia do Departamento de Produção Animal da ESALQ/USP, foi utilizado o método descrito por Chaney \& Marbach (1962), adaptado para leitura Leitor de Microplaca (BIO-RAD, Hercules, CA, EUA) utilizando-se filtro para absorbância de $550 \mathrm{~nm}$. Foram utilizadas a enzima urease (U-1500, Sigma), e soluções padrões com concentração de $0 ; 3,75 ; 7,5 ; 15$; e $30 \mathrm{mg} / \mathrm{dL}$ de $\mathrm{N}$-uréico. Somente foram aceitos resultados provenientes de placas com $r^{2}=0,99$ e coeficiente de variação de $5 \%$ entre duplicatas.

\subsubsection{Determinação de Ácidos Graxos Livres}

As concentrações de ácidos graxos não esterificados foram determinados enzimaticamente através do kit NEFA-c (Wako Chemicals GmbH, Richmond, VA) sendo o método modificado para leitura em Leitor de Microplaca (BIO-RAD, Hercules, CA, EUA) utilizando-se filtro para absorbância de $550 \mathrm{~nm}$. O padrão de $1 \mathrm{mEq} / \mathrm{L}$ de ácido oléico foi diluído com solução salina $(0,9 \% \mathrm{NaCl})$ nas concentrações de 0; 0,125; 0,5;0,75 e 1,0 mEq/L para obtenção de curva padrão. Cada amostra ou padrão foi então diluído com a solução na concentração de 1:4 (10 $\mu \mathrm{L}: 40 \mu \mathrm{L}$ ), também com a solução salina, através de pipetador automático, diretamente na microplaca. O volume de $50 \mu \mathrm{L}$ do Reagente $\mathrm{A}$ foi adicionado em 
cada poço da microplaca, a qual foi então agitada e incubada em estufa a $37^{\circ} \mathrm{C}$ durante 10 minutos. Decorrido este período foram então adicionados $100 \mu \mathrm{L}$ do Reagente $B$ sendo a placa agitada novamente e incubada nas mesmas condições. Após 10 minutos a placa foi retirada da estufa, sendo a leitura realizada após 3 minutos. O padrão de $1 \mathrm{mEq} / \mathrm{L}$ de ácido oléico foi utilizado como controle de qualidade da placa. Somente foram aceitos resultados provenientes de placas com $r^{2}=0,99$ e coeficiente de variação de $7 \%$ entre duplicatas.

\subsubsection{Análise Estatística}

Os dados apresentados de consumo de MS, peso vivo e ganho de peso diário foram analisados através do PROC MIXED do pacote SAS (1991), utilizando-se o peso ao nascer como covariável. Os dados de parâmetros sanguíneos também foram analisados a partir do PROC MIXED do pacote SAS (1991), levando em conta os efeitos hora e semana de colheita de amostra.

\subsection{Resultados e discussão}

A Tabela 2 apresenta a composição bromatológica dos diferentes concentrados experimentais, assim como a composição do feno fornecido após a desmama.

Tabela 2. Composição bromatológica dos concentrados e do feno.

$\begin{array}{lllll}F & \text { FM } & \mathrm{L} & \mathrm{LM} & \text { Feno }\end{array}$




\begin{tabular}{lccccc}
\hline \% MS & 95,61 & 95,86 & 95,46 & 95,85 & 95,51 \\
$\%$ PB & 17,74 & 17,29 & 17,26 & 18,22 & 7,62 \\
\% Amido & 50,48 & 48,91 & 49,63 & 50,22 & - \\
\% FDN & 6,21 & 5,92 & 7,52 & 8,38 & 69,50 \\
\% FDA & 2,09 & 2,00 & 2,15 & 2,29 & 33,11 \\
\% EE & 2,43 & 2,35 & 2,35 & 2,51 & 0,77 \\
\hline
\end{tabular}

${ }^{1} \mathrm{~F}=$ milho floculado, $\mathrm{FM}=$ milho floculado + monensina, $\mathrm{L}=$ milho laminado, $\mathrm{LM}=$ milho laminado + monensina.

Os dados de consumo de concentrado e feno (g MS/d) dos animais nos períodos que compreendem as semanas antes e após a desmama são apresentadas na Tabela 3. Os dados de consumo de feno se referem apenas ao período após a desmama uma vez que este não foi fornecido durante o período de aleitamento.

Os consumos de concentrado e feno, nos períodos pré e pós desmama, não foram afetados $(P>0,05)$ pelo processamento de grão ou pela adição de monensina. Os resultados observados estão abaixo da média esperada para bezerros leiteiros (Davis \& Drackley, 1998).

Esperava-se que as médias consumo de concentrado dos tratamentos contendo monensina (FM e LM) fossem inferiores ao consumo dos tratamentos sem monensina, uma vez que esta tem efeito inibidor do consumo de MS (Goodrich et al., 1984). Os resultados mostram que a monensina não afetou o consumo de concentrado, podendo ser incluída sem prejuízos a programas de desmama precoce baseados no consumo de concentrado, como sugerido por Quigley (1996). Entretanto, Nussio et al. (1997) observaram redução no consumo de MS em bezerros recebendo monensina em concentrado contendo grão floculado, no período após a desmama; sugerindo que o efeito inibidor ocorra somente quando o animal apresenta o rúmen parcialmente desenvolvido.

Tabela 3. Médias de consumo de concentrado e feno ( $\mathrm{g} \mathrm{MS} / \mathrm{d}$ ). 


\begin{tabular}{|c|c|c|c|c|c|c|c|c|}
\hline \multirow[b]{3}{*}{ Ração inicial } & \multicolumn{4}{|c|}{ Tratamentos } & \multirow[b]{2}{*}{$\mathrm{EPM}^{2}$} & \multicolumn{3}{|c|}{$P$} \\
\hline & $\mathrm{F}$ & FM & L & LM & & $\mathrm{G}^{3}$ & M & GxM \\
\hline & & & & & & & & \\
\hline Pré desmama & 126,28 & 109,41 & 97,92 & 117,22 & 112,7 & 0,75 & 0,97 & 0,58 \\
\hline À desmama & 246,75 & 220,23 & 250,34 & 257,3 & 96,04 & 0,94 & 0,74 & 0,65 \\
\hline Pós desmama & 1148,54 & 873,00 & 1155,05 & 1030,41 & 133,07 & 0,53 & 0,18 & 0,56 \\
\hline Total & 666,12 & 513,33 & 654,7 & 599,66 & 81,57 & 0,64 & 0,25 & 0,54 \\
\hline Feno & 77,85 & 65,45 & 78,10 & 65,18 & 21,09 & 0,99 & 0,56 & 0,99 \\
\hline
\end{tabular}

${ }^{1} \mathrm{~F}=$ milho floculado, $\mathrm{FM}=$ milho floculado + monensina, $\mathrm{L}=$ milho laminado, $\mathrm{LM}=$ milho laminado + monensina.

${ }^{2}$ Erro padrão da média.

${ }^{3} \mathrm{G}=$ efeito do processamento de grão, $M=$ efeito da adição de monensina, $\mathrm{GxM}=$ interação de processamento de grão e monensina.

O consumo de concentrado a desmama foi abaixo de $700 \mathrm{~g} / \mathrm{d}$, recomendado por Quigley (1996b), como sendo essencial para garantir que a desmama seja realizada com sucesso. Neste trabalho, estes níveis de consumo só ocorreram por volta da oitava semana, como pode ser observado na Figura 1, época em que a maioria dos produtores realiza a desmama. Entretanto, foi objetivo do trabalho avaliar o efeito do processamento de grão e adição de monensina em animais em regime de desmama mais precoce que a tradicional. A Figura 1 mostra que embora o consumo de concentrado tenha aumentado lentamente, não houve aumentos significativos até que o leite fosse retirado da dieta, o que também foi demonstrado por Tomkins et al. (1995). Entretanto, este efeito não foi associado a nenhum dos efeitos testados (grão e monensina) ou da interação dos mesmos. 


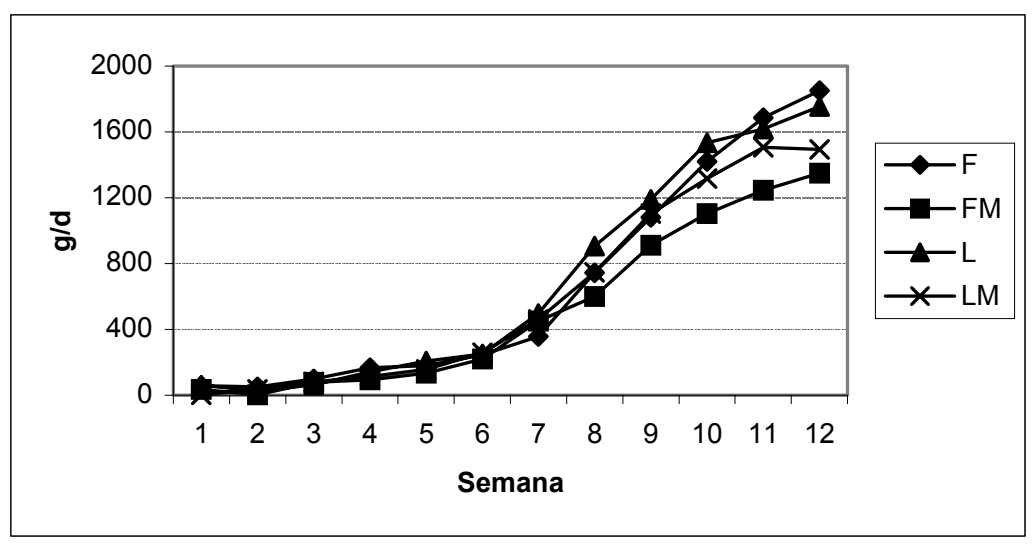

Figura 1 - Consumo semanal de Concentrado (g MS/d)

Fatores como a forma física do concentrado tem grande efeito no consumo, como observado por Beharka et al. (1998). Observou-se diferença na apreensão do concentrado, o que acarretou em seleção; entretanto, este efeito não foi associado a nenhum dos tratamentos, sendo o efeito animal o de maior peso. Pode-se observar animais em um mesmo tratamento consumindo preferencialmente grãos, enquanto outros consumiram preferencialmente a mistura melaço-farelo de soja-premix.

O consumo de feno não foi diferente entre os tratamentos $(P>0,05)$, não ocorrendo efeito de processamento de grão ou adição de monensina. A Figura 2 mostra que o consumo de feno aumentou durante a fase pós-desmama. Os baixos valores de consumo de concentrado a desmama devem ter levado a um menor desenvolvimento ruminal e, portanto, menor capacidade absortiva. Assim, o baixo consumo de feno pode demonstrar que os animais não estavam prontos do ponto de vista fisiológico para a desmama, ou seja, prontos para dependerem da dieta de um animal ruminante. 


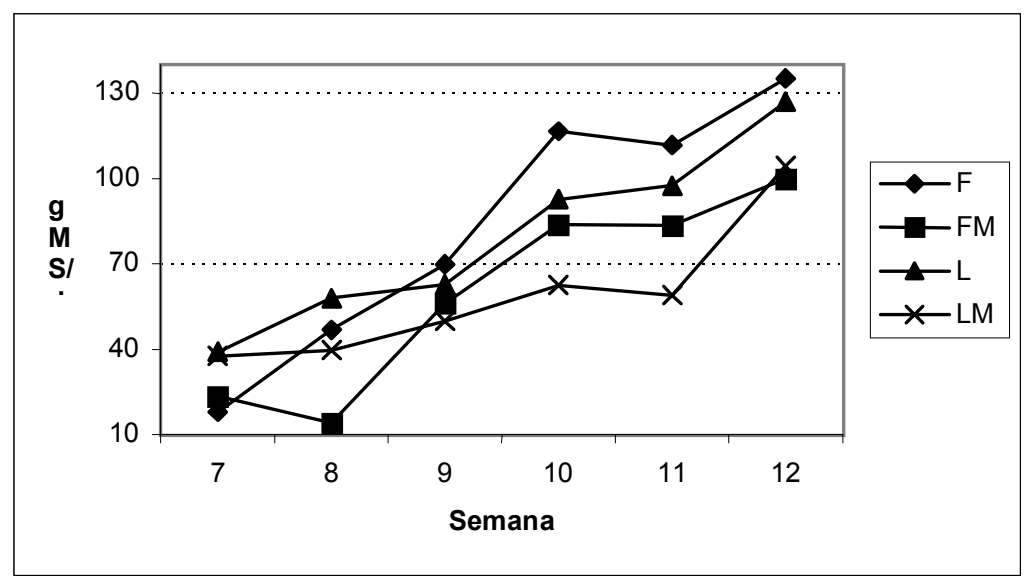

Figura 2 - Consumo de feno (g MS/d).

O processamento do milho e a adição de monensina não afetaram o desempenho de bezerros em termos de peso vivo final e ganho de peso diário, pré e pós desmama (Tabela 4 e 5). As baixas taxas de ganho de peso após a desmama refletem o efeito negativo da desmama precoce quando os animais não apresentavam consumo de concentrado de $700 \mathrm{~g} / \mathrm{d}$. As taxas de crescimento animal estiveram abaixo dos padrões recomendados na literatura com vistas à produção de fêmeas de reposição, com peso adequado por volta de 24 meses de idade (Heinrichs \& Losinger, 1997; Hoffman, 1997). O baixo desempenho animal observado até as 12 semanas de idade não poderá ser compensado na próxima fase de vida do animal (período pré-púbere), sem que haja riscos de afetar negativamente o desenvolvimento da glândula mamária, assim como o peso e condição corporal ao parto, como demonstrado por inúmeros trabalhos (Lacasse et al., 1993; Serjsen, 1994). O baixo consumo de concentrado dever estar relacionado com falhas no manejo destes animais uma vez que Nussio (1997) observaram desempenho dentro das recomendações de literatura fornecendo concentrado similar, formulado com grão floculado e inclusão de monensina. 
Tabela 4. Peso vivo do animais $(\mathrm{kg} / \mathrm{d})$.

\begin{tabular}{|c|c|c|c|c|c|c|c|c|}
\hline & \multicolumn{4}{|c|}{ Tratamentos } & \multirow[b]{2}{*}{ EPM $^{2}$} & \multicolumn{3}{|c|}{$P$} \\
\hline & $\mathrm{F}$ & FM & $\mathrm{L}$ & LM & & $\mathrm{G}^{3}$ & M & GxM \\
\hline Pré desmama & 40,00 & 39,92 & 40,42 & 40,33 & 0,72 & 0,56 & 0,91 & 0,99 \\
\hline À desmama & 46,58 & 45,68 & 46,62 & 46,65 & 2,46 & 0,74 & 0,66 & 0,84 \\
\hline Pós desmama & 54,67 & 53,37 & 55,59 & 53,72 & 2,66 & 0,81 & 0,57 & 0,91 \\
\hline 12 semanas & 64,66 & 60,05 & 65,24 & 60,92 & 2,46 & 0,74 & 0,66 & 0,84 \\
\hline
\end{tabular}

${ }^{1} \mathrm{~F}=$ milho floculado, $\mathrm{FM}=$ milho floculado + monensina, $\mathrm{L}=$ milho laminado, $\mathrm{LM}=$ milho laminado + monensina.

2 Erro padrão da média.

${ }^{3} \mathrm{G}=$ efeito do processamento de grão, $M=$ efeito da adição de monensina, $\mathrm{GxM}=$ interação de processamento de grão e monensina.

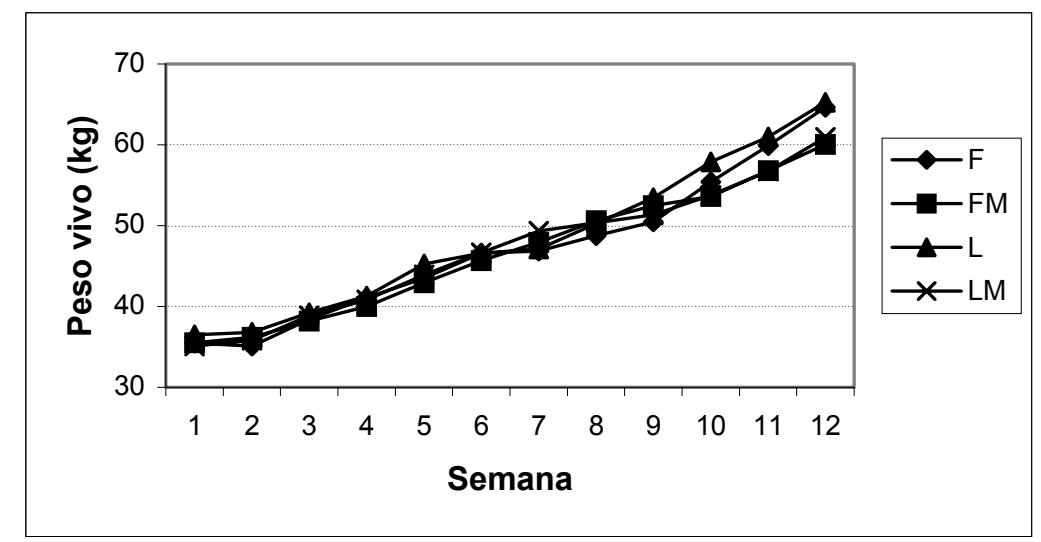

Figura 3 - Peso Animal (kg) 
Tabela 5. Ganho de Peso Vivo (g/d).

\begin{tabular}{|c|c|c|c|c|c|c|c|c|}
\hline & \multicolumn{4}{|c|}{ Tratamentos } & & \multicolumn{3}{|c|}{ P } \\
\hline & $\mathrm{F}$ & FM & $\mathrm{L}$ & LM & $\mathrm{EPM}^{2}$ & $\mathrm{G}^{3}$ & $M$ & GxM \\
\hline Pré desmama & 306,58 & 292,02 & 297,24 & 288,56 & 59,00 & 0,93 & 0,84 & 0,95 \\
\hline Pós desmama & 426,34 & 334,14 & 456,96 & 355,89 & 74,05 & 0,72 & 0,22 & 0,95 \\
\hline Total & 351,83 & 354,66 & 372,52 & 323,17 & 59,26 & 0,92 & 0,71 & 0,66 \\
\hline
\end{tabular}

${ }^{1} \mathrm{~F}=$ milho floculado, $\mathrm{FM}=$ milho floculado + monensina, $\mathrm{L}=$ milho laminado, $\mathrm{LM}=$ milho laminado + monensina.

${ }^{2}$ Erro padrão da média.

${ }^{3} \mathrm{G}=$ efeito do processamento de grão, $M=$ efeito da adição de monensina, $\mathrm{GxM}=$ interação de processamento de grão e monensina.

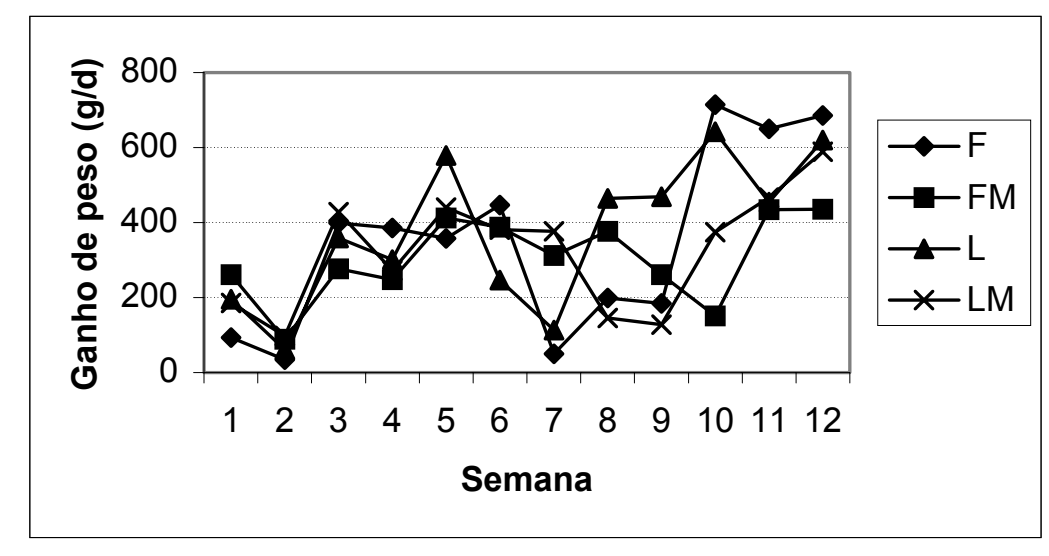

Figura 4 - Ganho de peso animal (g/d)

A literatura mostra inconsistência com relação aos dados de desempenho de bezerros leiteiros recebendo ionóforos. Vários trabalhos têm demostrado o benefício da inclusão destes produtos no concentrado ou substituto de leite (Fitzgerald et al., 1984; Watkins et al., 1987; Sinks et al., 1992; Quigley et al., 1996). Por outro lado outros autores não observaram este efeito (Stockdale \& Sheard, 1982; Foreyt et al., 1986). É provável que as diferenças observadas com relação ao desempenho, estejam relacionadas a ação diferenciada de ionóforos em animais com o rúmen em desenvolvimento mais precoce ou mais tardio, de acordo com o sistema de produção e desmama dos animais nos diferentes 
trabalhos.

Schuh et al. (1970 a) e Daniels (1972) também não observaram benefícios do processamento de grãos no que se refere a consumo de concentrado. Entretanto, em trabalho subsequente, Schuh et al. (1970 b) observaram maior consumo e ganho de peso, com sorgo floculado em comparação ao sorgo cozido a vapor. É possível que o efeito observado com o processamento de sorgo e não com o grão de milho, se deva ao fato do primeiro ser mais responsivo ao processamento (Theurer, 1986).

Mesmo com diferentes intensidades de processamento de milho (moagem vs. floculação), Bagaldo et al. (2001) não observaram diferenças no desempenho de bezerros leiteiros antes e após a desmama. É provável que o processamento de grãos não seja tão importante para um animal com o rúmen em desenvolvimento, como para um animal ruminante funcional.

A Tabela 6 apresenta os valores médios das concentrações de glicose, Nuréico e AGL no plasma dos animais. A floculação do milho e a adição de monensina não afetaram $(P>0,05)$ as concentrações de glicose plasmática nas primeiras 12 semanas de vida dos animais. De modo geral, a floculação de milho ou sorgo aumenta a disponibilidade de glicose para vacas em lactação devido à maior síntese hepática (Theurer et al., 1999). A maior digestibilidade de amido no rúmen resulta em maior produção de $A G V$, principalmente propionato. Uma vez que propionato é o principal precursor de glicose no fígado, esperava-se um aumento nos níveis de glicose no plasma de bezerras recebendo milho floculado. Da mesma forma, também se esperava um aumento nos níveis de glicose plasmática com a suplementação de monensina por esta está associada a aumentos de propionato no rúmen devido (Sauer et al., 1989). Quigley et al. (1992) observaram uma tendência de maior glicose plasmática com a administração de lasalocida, somente após a desmama de bezerros leiteiros. Por outro lado, EicherPruiett et al. (1992) não observaram efeito da administração de lasalocida neste parâmetro. 
Tabela 6. Médias dos quadrados mínimos dos parâmetros sanguíneos durante o período experimental.

\begin{tabular}{|c|c|c|c|c|c|c|c|c|}
\hline \multirow[b]{2}{*}{ Parâmetro } & \multicolumn{4}{|c|}{ Tratamentos } & \multirow[b]{2}{*}{$\mathrm{EPM}^{2}$} & \multicolumn{3}{|c|}{$\mathrm{P}$} \\
\hline & $\mathrm{F}$ & FM & $\mathrm{L}$ & LM & & $\mathrm{G}^{3}$ & $M$ & GxM \\
\hline Glicose, mg/dL & 72,23 & 73 & 75,46 & 69,65 & 3,88 & 0,93 & 0,57 & 0,37 \\
\hline - & $9,28^{\mathrm{ab}}$ & $10,06^{a}$ & 9,72 & $7,77^{b}$ & 0 & 0,23 & 0,43 & 0,08 \\
\hline $\mathrm{GL}, \mu \mathrm{mol} / \mathrm{L}$ & 221,06 & 237,76 & 215,39 & 235,24 & 19,02 & 0,83 & 0,35 & 0,93 \\
\hline
\end{tabular}

${ }^{1} \mathrm{~F}=$ milho floculado, $\mathrm{FM}=$ milho floculado + monensina, $\mathrm{L}=$ milho laminado, $\mathrm{LM}=$ milho laminado + monensina.

${ }^{2}$ Erro padrão da média. ${ }^{3} \mathrm{G}=$ efeito do processamento de grão, $M=$ efeito da adição de monensina, $\mathrm{GxM}=$ interação de processamento de grão e monensina.

${ }^{a, b, c}$ Letras minúsculas na mesma coluna diferem estatisticamente para $\mathrm{P}<0,0001$.

Embora tenha ocorrido efeito significativo de semana $(P<0,0001)$ e de horário após o fornecimento de alimento $(P<0,0001)$ para glicose plasmática, como mostram as Tabelas 7 e 8 , as interações semana $x$ tratamento e horário $x$ tratamento não apresentaram efeitos significativas $(P>0,05)$.

Conforme esperado, a Tabela 7 e a Figura 5 mostram claramente uma redução nos níveis de glicose plasmática com o avanço da idade dos animais. Williams et al. (2001) também observaram clara redução nos níveis de glicose com o avanço da idade de bezerros, principalmente após a desmama. Os valores médios observados são comparáveis àqueles encontrados por Quigley \& Bernard (1992). Entretanto, estes autores não observaram redução nos níveis de glicose com a idade dos animais na fase de aleitamento

Tabela 7. Média dos quadrados mínimos dos níveis de glicose plasmática nas semanas de experimento $(\mathrm{m} / \mathrm{dL})$. 


\begin{tabular}{ccccccc}
\hline & \multicolumn{5}{c}{ Tratamentos } & \\
\cline { 2 - 4 } Semana & $F^{1}$ & $F M$ & $L$ & LM & EPM $^{2}$ & Subparcela $^{3}$ \\
\hline 1 & 85,41 & 89,36 & 84,12 & 87,18 & 5,65 & $86,52^{\text {a }}$ \\
2 & 81,75 & 82,73 & 83,55 & 78,89 & 5,29 & $81,73^{\text {ab }}$ \\
3 & 74,12 & 81,09 & 82,88 & 74,42 & 5,24 & $78,13^{\text {b }}$ \\
4 & 76,16 & 74,49 & 77,17 & 66,70 & 5,39 & $73,63^{\text {bc }}$ \\
5 & 67,62 & 71,78 & 72,41 & 74,70 & 5,29 & $71,62^{\mathrm{c}}$ \\
6 & 73,95 & 74,11 & 77,72 & 67,73 & 5,25 & $73,37^{\text {bc }}$ \\
7 & 62,92 & 60,23 & 61,21 & 52,56 & 5,48 & $59,23^{\mathrm{d}}$ \\
8 & 55,88 & 54,43 & 64,62 & 54,98 & 5,25 & $57,48^{\mathrm{d}}$ \\
\hline
\end{tabular}

${ }^{1} \mathrm{~F}=$ milho floculado, $\mathrm{FM}=$ milho floculado + monensina, $\mathrm{L}=$ milho laminado, $\mathrm{LM}=$ milho laminado + monensina.

${ }^{2}$ Erro padrão da média.

${ }^{3}$ Subparcela, média de todos os tratamentos.

a,b,c Letras minúsculas na mesma coluna diferem estatisticamente para $\mathrm{P}<0,0001$.

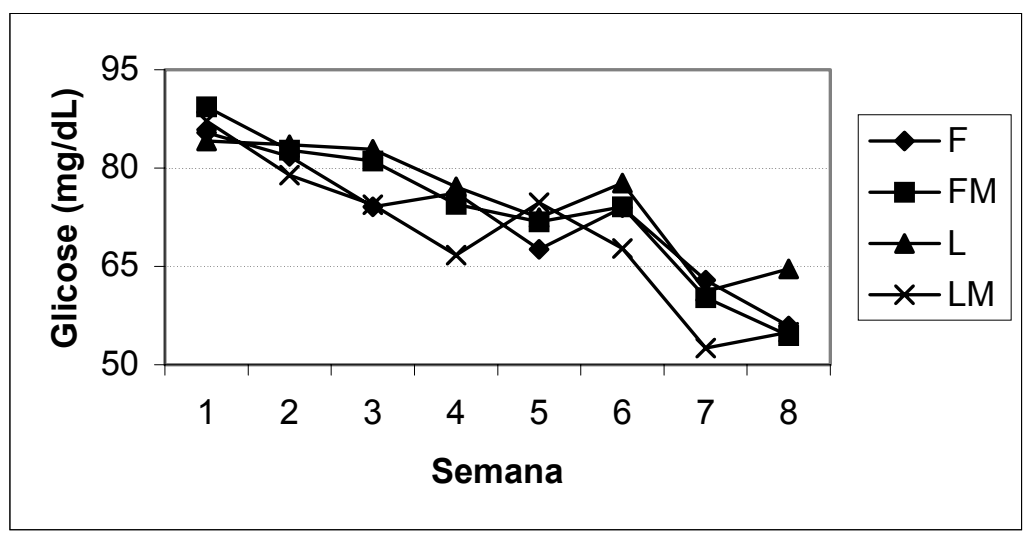

Figura 5 - Média dos quadrados mínimos dos níveis de glicose plasmática com a idade do animal.

Os maiores níveis de glicose plasmática foram observados 2 horas após o fornecimento do alimento (Tabela 8 e Figura 6), fato também observado em outros trabalhos (Quigley et al., 1991 a; Quigley \& Bernard, 1992). O pico de glicose 2 horas após o fornecimento do alimento sugere rápida fermentação do concentrado 
consumido. Entretanto como mostra a Figura 7, o pico de glicose ocorreu somente até a semana 6 , ou seja durante a fase de aleitamento. Os níveis de glicose 2 horas após a alimentação durante as semanas de 1 a 6 foram superiores aos níveis das semanas 7 e $8(P<0,001)$. Estas diferenças se devem mais aos elevados níveis de glicose em bezerros em aleitamento do que à redução resultante do desenvolvimento do rúmen (Quigley et al., 1991 a). Além disso, o pico de glicose varia conforme a fonte da mesma entrando na circulação do animal. Enquanto o pico de glicose absorvida diretamente ocorre mais cedo, o pico daquela proveniente de gluconeogênese a partir de propionato ruminal ocorre mais tardiamente.

Tabela 7. Média dos quadrados mínimos dos níveis de glicose plasmática nos horários após a alimentação (m/dL).

\begin{tabular}{|c|c|c|c|c|c|c|}
\hline \multirow[b]{2}{*}{ Horário } & \multicolumn{4}{|c|}{ Tratamentos } & \multirow[b]{2}{*}{$\mathrm{EPM}^{2}$} & \multirow[b]{2}{*}{ Subparcela ${ }^{3}$} \\
\hline & $\mathrm{F}^{1}$ & FM & $\mathrm{L}$ & LM & & \\
\hline 0 & 68,25 & 67,08 & 72,66 & 67,56 & 4,73 & $68,89^{\text {cd }}$ \\
\hline 2 & 81,28 & 82,67 & 81,11 & 78,99 & 4,79 & $81,01^{a}$ \\
\hline 4 & 75,59 & 75,57 & 77,9 & 73,74 & 4,72 & $75,70^{\mathrm{b}}$ \\
\hline 8 & 70,62 & 73,44 & 76,01 & 66,60 & 4,81 & $71,67^{\mathrm{bc}}$ \\
\hline 12 & 65,37 & 68,88 & 69,62 & 61,33 & 4,82 & $66,30^{d}$ \\
\hline
\end{tabular}




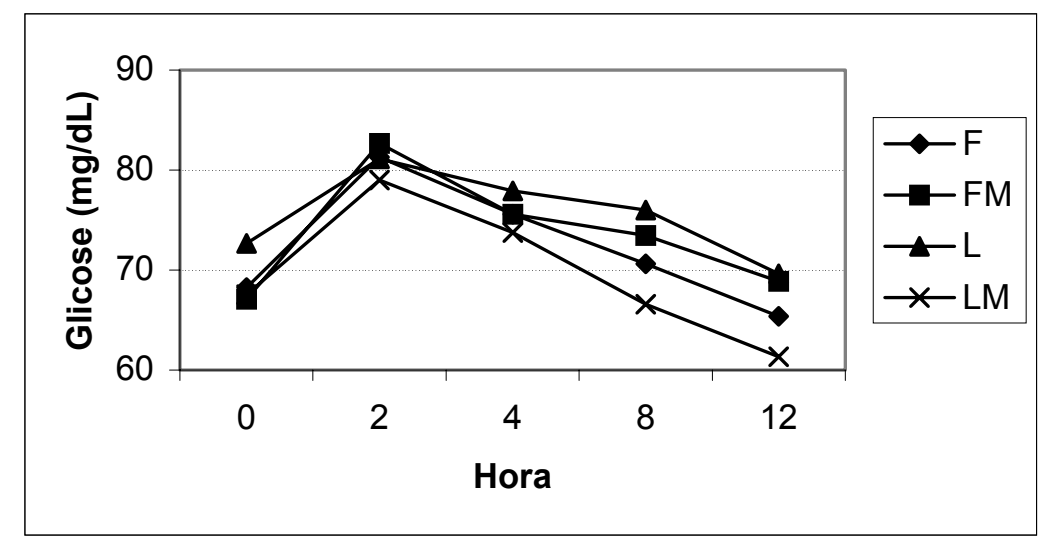

Figura 6 - Média dos quadrados mínimos dos níveis de glicose plasmática nos horários após a alimentação.

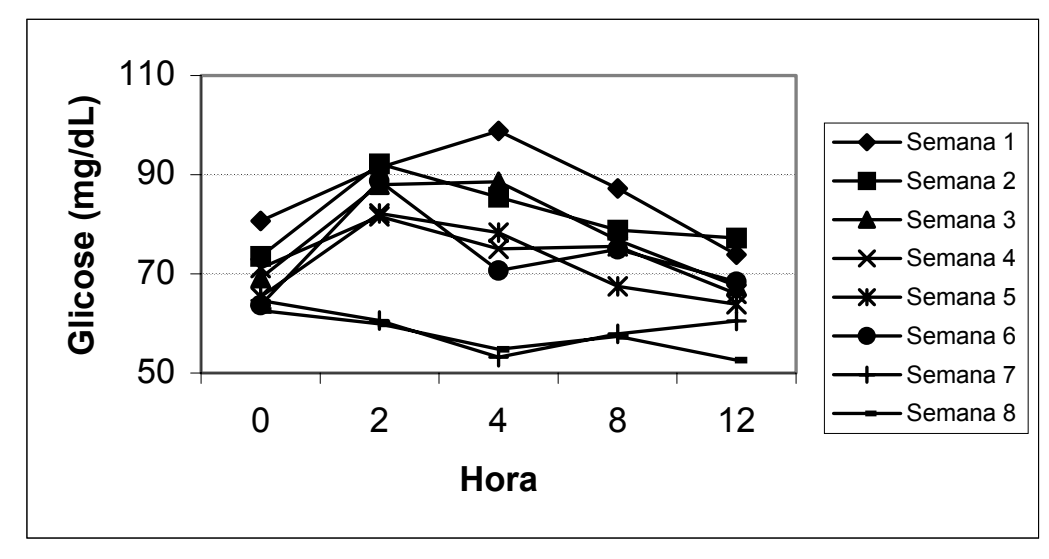

Figura 7 - Interação semana x hora nos níveis de glicose plasmática.

Não foi observado efeito significativo $(P>0,05)$ de processamento de grão ou da inclusão de monensina nos níveis de $\mathrm{N}$-uréico. Entretanto, houve tendência $(P=0,08)$ da interação destes fatores, de forma que os animais alimentados com o tratamento LM apresentaram os menores níveis de uréia plasmática (Tabela 6). Adicionalmente, houve interação significativa $(P<0,0001)$ entre semana e monensina, e semana e processamento de grão.

Eicher-Pruiett e colaboradores (1992) observaram redução nos níveis de Nuréico no plasma com o fornecimento de lasalocida para bezerros leiteiros. 
Segundo estes autores, os níveis de $\mathrm{N}$-uréico plasmáticos aumentam com o consumo de alimento, acompanhando os aumentos nos níveis de amônia ruminal em bezerros, como observado por Anderson et al. (1988). No trabalho de Quigley \& Bernard (1992), os níveis de N-uréico foi positivamente relacionado ao consumo de concentrado, indicando extensiva degradação ruminal de proteína em bezerros com o rúmen em desenvolvimento.

Os níveis de $\mathrm{N}$-uréico deste trabalho são superiores àqueles observados por Quigley et al. (1992), mas comparáveis aos de Eicher-Pruiett et al. (1992), ambos trabalhos com fornecimento de lasalocida.

De acordo com McGuffey (2001), a monensina reduz a deaminação aminoácidos, podendo reduzir a produção de amônia ruminal e consequentemente os níveis de $\mathrm{N}$-uréico circulantes no plasma. Entretanto, a interação de fornecimento de monensina e grão laminado gerando os menores níveis de $\mathrm{N}$-uréico não era esperada. Vários trabalhos têm demonstrado maior reciclagem de $\mathrm{N}$ para o rúmen com o fornecimento de grão floculado (Reynolds \& Huntington, 1988; Huntington et al., 1997).

Embora tenha ocorrido efeito significativo de semana nos níveis de $\mathrm{N}$-uréico (Tabela 9), não houve um padrão de variação com o avanço da idade animal, como pode ser observado na Figura 8. Além disso, apesar de diferenças no níveis de $\mathrm{N}$-uréico, principalmente nas semanas 2, 7 e 8, estas não foram significativas.

Tabela 9. Média dos quadrados mínimos dos níveis de N-uréico plasmático dos 
tratamentos nas semanas de experimento $(\mathrm{m} / \mathrm{dL})$.

\begin{tabular}{|c|c|c|c|c|c|c|}
\hline \multirow[b]{2}{*}{ Semana } & \multicolumn{4}{|c|}{ Tratamentos } & \multirow[b]{2}{*}{ EPM } & \multirow[b]{2}{*}{ Subparcela } \\
\hline & $\mathrm{F}^{1}$ & FM & $L$ & LM & & \\
\hline 1 & 6,21 & 6,20 & 10,33 & 6,46 & 1,12 & $7,30^{\mathrm{c}}$ \\
\hline 2 & 9,60 & 7,96 & 12,74 & 7,70 & 1,05 & $9,50^{b}$ \\
\hline 3 & 10,34 & 10,86 & 10,06 & 8,05 & 1,05 & $9,83^{b}$ \\
\hline 4 & 9,34 & 10,43 & 9,33 & 8,12 & 1,07 & $9,31^{b c}$ \\
\hline 5 & 9,58 & 9,28 & 10,15 & 7,16 & 1,06 & $9,04^{b c}$ \\
\hline 6 & 7,12 & 8,65 & 9,79 & 7,96 & 1,04 & $8,38^{\mathrm{c}}$ \\
\hline 7 & 12,29 & 14,71 & 8,54 & 8,54 & 1,11 & $11,02^{\mathrm{a}}$ \\
\hline 8 & 9,78 & 12,42 & 6,97 & 8,14 & 1,03 & $9,33^{b c}$ \\
\hline
\end{tabular}

${ }^{1} \mathrm{~F}=$ milho floculado, $\mathrm{FM}=$ milho floculado + monensina, $\mathrm{L}=$ milho laminado, $\mathrm{LM}=$ milho laminado + monensina.

${ }^{2}$ Subparcela, média de todos os tratamentos.

${ }^{a, b, c}$ Letras minúsculas na mesma coluna diferem estatisticamente para $\mathrm{P}<0,0001$.

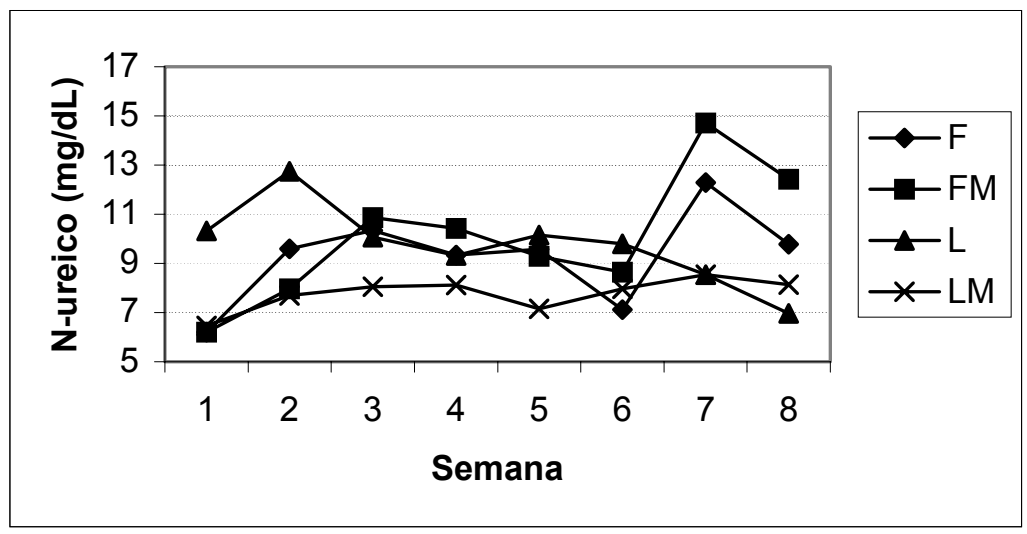

Figura 8 - Média dos quadrados mínimos dos níveis de N-uréico plasmático com a idade do animal.

Não houve efeito significativo de horário após a alimentação nos níveis de N-uréico plasmático, como mostram a Tabela 10 e a Figura 9. Não foi possível observar um padrão de variação nos níveis deste metabólito com o horário após a 
alimentação, sugerindo que as variações durante o dia não representam mudanças no padrão de fermentação ruminal.

Tabela 10. Média dos quadrados mínimos dos níveis de $\mathrm{N}$-uréico dos tratamentos nos horários após a alimentação (m/dL).

\begin{tabular}{ccccccc}
\hline & \multicolumn{5}{c}{ Tratamentos } & \\
\cline { 2 - 4 } Horário & $\mathrm{F}^{1}$ & $\mathrm{FM}$ & $\mathrm{L}$ & $\mathrm{LM}$ & EPM $^{2}$ & Subparcela $^{3}$ \\
\hline 0 & 9,23 & 10,49 & 9,87 & 7,82 & 0,92 & 9,35 \\
2 & 10,43 & 10,13 & 9,33 & 7,93 & 0,94 & 9,46 \\
4 & 9,29 & 9,84 & 9,35 & 7,85 & 0,93 & 9,08 \\
8 & 8,80 & 9,55 & 10,33 & 7,52 & 0,95 & 9,05 \\
12 & 8,66 & 10,30 & 9,81 & 7,70 & 0,95 & 9,11
\end{tabular}

${ }^{1} \mathrm{~F}=$ milho floculado, $\mathrm{FM}=$ milho floculado + monensina, $\mathrm{L}=$ milho laminado, $\mathrm{LM}=$ milho laminado + monensina.

${ }^{2}$ Erro padrão da média.

${ }^{3}$ Subparcela, média de todos os tratamentos.

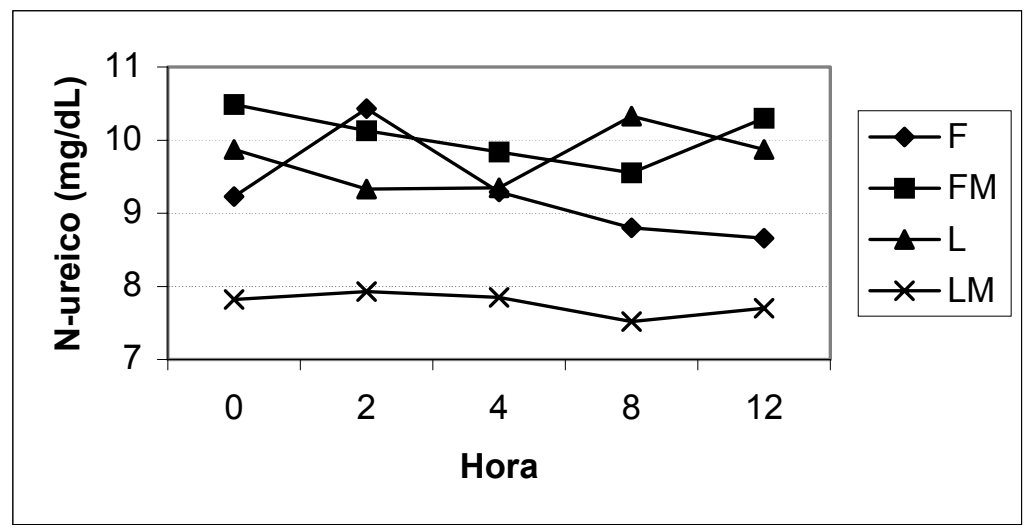

Figura 9 - Média dos quadrados mínimos dos níveis de $\mathrm{N}$-uréico plasmático nos horários após a alimentação.

Não observou-se efeito do tipo de processamento de grão ou inclusão de monensina na média dos níveis de AGL durante todo o período experimental (Tabela 6). 
A inclusão de lasalocida no concentrado de bezerros reduziu os níveis de AGL no trabalho de Quigley e colaboradores (1992). O aumento na produção ruminal de propionato, devido a inclusão de ionóforos na dieta, aumenta a disponibilidade de energia para o animal, resultando em uma menor necessidade de mobilização de lipídeos; o que seria interessante para animais logo após a desmama. O mesmo efeito é causado pelo fornecimento de dietas com amido mais degradável no rúmen, como é o caso de milho floculado. Entretanto, este efeito não foi observado neste trabalho, antes ou após a desmama.

As concentrações de AGL obtidos são comparáveis aos publicados por Quigley et al. (1991 a), mas inferiores aos obtidos em trabalho com a administração de lasalocida para bezerros (Quigley et al., 1992 a). As concentrações observadas de AGL podem estar relacionados ao baixo consumo de concentrado e portanto maior mobilização de lipídeos, o que explica o baixo ganho de peso dos animais. Entretanto, os níveis sofreram redução com o avanço da idade do animal $(\mathrm{P}<0,0001)$, assim como em outros trabalhos (Quigley et al., 1991 a; Quigley \& Bernard, 1992; Quigley, 1996).

As concentrações de AGL no plasma também fora afetadas pelo horário após a alimentação $(P<0,0001)$ como demonstram a Tabela 12 e a Figura 11. Trenkle \& Kuhlmeier (1996) observaram uma relação negativa entre AGL e glicose plasmática e sugerem que este fato ocorre devido a alta sensibilidade dos níveis de AGL às concentrações de glicose e AGV. Pode-se observar uma relação negativa entre estes dois metabólitos através das Figuras 6 e 11.

Tabela 11. Média dos quadrados mínimos dos tratamentos dos níveis de ácidos graxos livres no plasma nas semanas de experimento ( $\mu \mathrm{mol} / \mathrm{L}$ ). 


\begin{tabular}{|c|c|c|c|c|c|c|}
\hline \multirow[b]{2}{*}{ Semana } & \multicolumn{4}{|c|}{ Tratamentos } & \multirow[b]{2}{*}{$\mathrm{EPM}^{2}$} & \multirow[b]{2}{*}{ Subparcela ${ }^{3}$} \\
\hline & $\mathrm{F}^{1}$ & FM & $\mathrm{L}$ & LM & & \\
\hline 1 & 269,15 & 283,55 & 251,27 & 283,15 & 30,18 & $271,78^{a}$ \\
\hline 2 & 216,98 & 264,60 & 268,21 & 294,05 & 28,68 & $260,96^{a b}$ \\
\hline 3 & 252,07 & 267,95 & 223,06 & 248,35 & 27,78 & $247,8^{a b}$ \\
\hline 4 & 242,55 & 221,54 & 231,19 & 249,58 & 28,64 & $236,21^{b}$ \\
\hline 5 & 250,20 & 254,60 & 238,48 & 253,90 & 27,77 & $249,29^{a b}$ \\
\hline 6 & 181,81 & 201,31 & 210,55 & 225,75 & 27,68 & $204,85^{c}$ \\
\hline 7 & 222,43 & 229,05 & 146,62 & 191,38 & 29,24 & $197,37^{\mathrm{c}}$ \\
\hline 8 & 133,35 & 179,47 & 153,74 & 135,78 & 27,53 & $150,58^{d}$ \\
\hline
\end{tabular}

${ }^{1} \mathrm{~F}=$ milho floculado, $\mathrm{FM}=$ milho floculado + monensina, $\mathrm{L}=$ milho laminado, $\mathrm{LM}=$ milho laminado + monensina.

2 Erro padrão da média.

${ }^{3}$ Subparcela, média de todos os tratamentos.

a,b,c Letras minúsculas na mesma coluna diferem estatisticamente para $\mathrm{P}<0,02$.

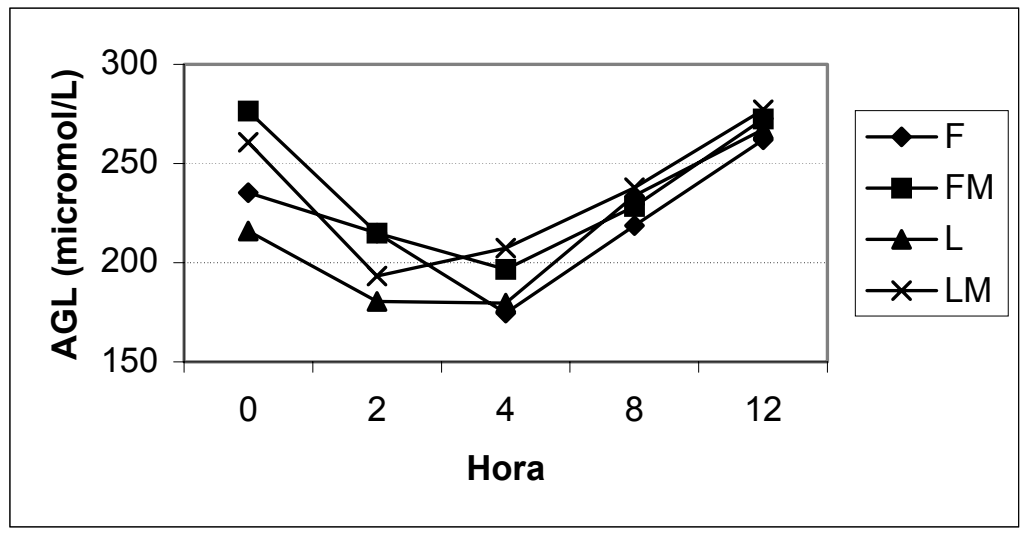

Figura 10 - Média dos quadrados mínimos dos níveis de AGL plasmático com a idade do animal.

Tabela 12. Média dos quadrados mínimos dos tratamentos dos níveis de ácidos 
graxos livres no plasma nas semanas de experimento ( $\mu \mathrm{mol} / \mathrm{L})$.

\begin{tabular}{|c|c|c|c|c|c|c|}
\hline \multirow[b]{2}{*}{ Horário } & \multicolumn{4}{|c|}{ Tratamentos } & \multirow[b]{2}{*}{$\mathrm{EPM}^{2}$} & \multirow[b]{2}{*}{ Subparcela ${ }^{3}$} \\
\hline & $F^{1}$ & FM & L & LM & & \\
\hline$\overline{0}$ & 235,40 & 276,49 & 215,90 & 260,65 & 24,53 & $247,11^{b}$ \\
\hline 2 & 214,89 & 214,89 & 180,37 & 193,36 & 24,89 & $200,88^{c}$ \\
\hline 4 & 174,51 & 196,62 & 179,56 & 207,37 & 24,48 & $189,52^{c}$ \\
\hline 8 & 218,64 & 228,29 & 233,92 & 237,81 & 24,96 & $229,66^{\mathrm{b}}$ \\
\hline 12 & 261,88 & 272,50 & 267,21 & 277,00 & 25,57 & $269,65^{\mathrm{a}}$ \\
\hline
\end{tabular}

${ }^{1} \mathrm{~F}=$ milho floculado, $\mathrm{FM}=$ milho floculado + monensina, $\mathrm{L}=$ milho laminado, $\mathrm{LM}=$ milho laminado + monensina.

${ }^{2}$ Erro padrão da média.

${ }^{3}$ Subparcela, produção média de todos os tratamentos.

${ }^{a, b, c}$ Letras minúsculas na mesma coluna diferem estatisticamente para $\mathrm{P}<0,0001$.

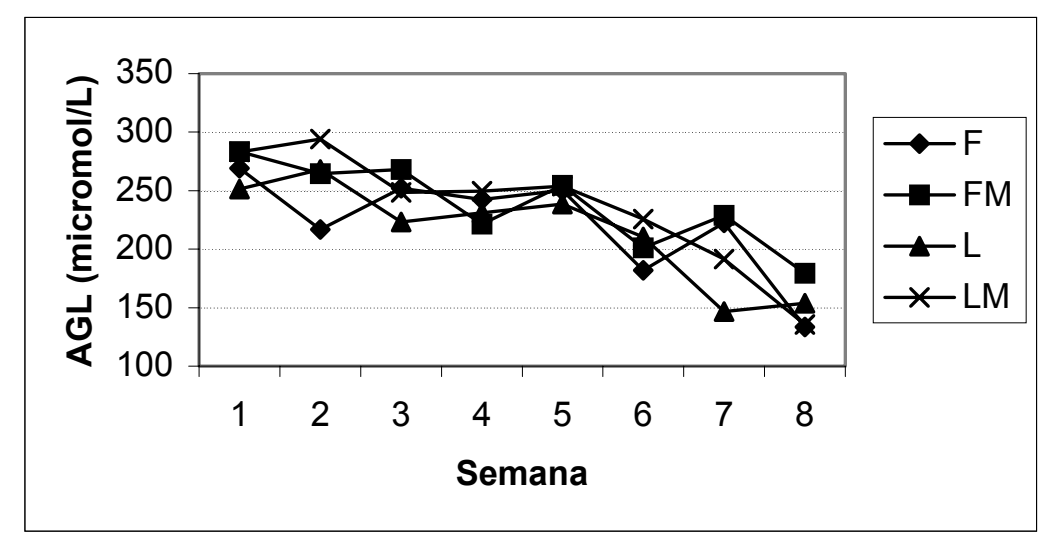

Figura 11 - Média dos quadrados mínimos dos níveis de AGL plasmático nos horários após a alimentação.

\subsection{Conclusões}

A floculação do milho, apesar de comprovadamente benéfica para bovinos com o rúmen plenamente funcional, não melhora o desempenho de animais mais jovens, na fase pré desmama, e durante as primeiras semanas pós desmama. 
Apesar de, reconhecidamente eficaz no controle de coccidiose em bezerros em aleitamento, a inclusão de monensina, para bezerros criados em condições sanitárias adequadas, parece ser pouco promissora quando o objetivo é melhor desempenho via alterações nos padrões de fermentação ruminal. 


\title{
4 DESENVOLVIMENTO RUMINAL E PARÂMETROS SANGUÍNEOS DE BEZERROS LEITEIROS SUPLEMENTADOS COM MILHO PROCESSADO (FLOCULADO vS. LAMINADO A VAPOR) E MONENSINA.
}

\author{
Autor: Carla Maris Bittar Nussio \\ Orientador: Prof. Dr. Flávio Augusto Portela Santos
}

\section{Resumo}

O objetivo deste trabalho foi o de avaliar as alterações do fornecimento de grãos processados (laminado a vapor vs. floculado) e monensina em parâmetros ruminais e sanguíneos. Dezesseis bezerros holandeses foram fistulados no rúmen com 3-5 dias de vida e agrupados em blocos ao acaso, com arranjo fatorial 2x2. Os animais receberam concentrado ad libitum até o consumo de $2 \mathrm{~kg} / \mathrm{d}$, 4 litros diários de leite e tiveram acesso livre à água. Após a desmama, realizada na oitava semana de vida, os animais passaram a receber $2 \mathrm{~kg} / \mathrm{d}$ de concentrado e feno picado ad libitum. Os tratamentos não afetaram $(P>0,05)$ o consumo de concentrado e feno, assim como o desempenho animal. A concentração molar de propionato $(P<0,05)$ foi maior para animais recebendo grão laminado. Houve tendência de maior concentração molar de $A G V$ total $(P=0,11)$ e butirato $(P=0,13)$ para animais recebendo grão laminado. A inclusão de monensina tendeu a reduzir as concentrações de $\mathrm{N}-\mathrm{NH}_{3}$ ruminal $(\mathrm{P}=0,12)$. O peso do retículo-rúmen (\% trato total) tendeu $(P=0,09)$ a ser maior em animais recebendo grão laminado e monensina. A capacidade do retículo-rúmen foi aumentada $(P<0,05)$ pelo fornecimento de grão laminado e monensina. Milho floculado resultou em menor 
peso do abomaso em \% trato total $(P<0,01)$.

\section{Ruminal development and blood parameters of dairy calves fed processed corn (steam-rolled vs. steam-flaked) and monensin.}

\section{Summary}

The objective of this study was the evaluation of the effects of grain processing (steam-rolled vs. steam-flaked) and monensin on ruminal and blood parameters. Sixteen Holstein calves were ruminally canulated with 3 to 5 days of life, and utilized on a completely randomized design block with a $2 \times 2$ factorial arrangement. The animals received concentrate ad libitum up to $2 \mathrm{~kg} / \mathrm{d}$, plus $4 \mathrm{~L} / \mathrm{d}$ of milk. Calves had free access to water. After weaning at the eight weeks of life, calves received concentrate and chopped hay. Animal performance, concentrate and hay intakes were lower than expected and not affected $(P>0,05)$ by treatments. The molar proportion of propionate was higher $(P<0,05)$ for steam-rolled concentrate. There was a tendency for higher total VFA $(P=0,11)$ and butyrate $(P=0,13)$ for steamrolled corn. Monensin tended to reduce ruminal $\mathrm{N}-\mathrm{NH}_{3}$ concentration $(P=0,12)$. Weight of reticulum-rumen (as $\%$ total tract) tended to be higher $(P=0,09)$ for calves on steam-rolled and monensin concentration. However, the capacity of reticulumrumen was increased by steam-rolled and monensin feeding $(P<0,05)$. Steamflaked concentrate resulted on heavier abomasum, as \% total tract $(P<0,01)$.

\subsection{Introdução}

$\mathrm{O}$ alto custo de produção de bezerros leiteiros principalmente na fase de aleitamento têm levado à busca de ferramentas de manejo que permitam a 
desmama precoce. Entretanto, a desmama só é realizada de maneira adequada, sem prejuízos ao desempenho animal, quando este apresenta o rúmen ao menos parcialmente desenvolvido, capaz de assumir uma dieta de ruminante (Quigley, 1996b).

O desenvolvimento de bezerros recém-nascidos à condição de ruminante funcional, envolve uma série de mudanças anatômicas e fisiológicas no seu aparelho digestivo (Beharka et al., 1998). Embora o desenvolvimento do aparelho digestivo desses animais seja inato, a idade do animal per se tem pouco efeito.

Ao nascer estes animais apresentam o retículo-rúmen pouco desenvolvido e não funcional, representando apenas $30 \%$ do total dos quatro compartimentos (Crowley, 1991). As maiores mudanças em termos de desenvolvimento vão ocorrer no retículo-rúmen, o qual será colonizado por diferentes tipos de bactérias e terá sua musculatura e parede interna (papilas) desenvolvidas, como também enzimas funcionais na parede do rúmen. Por volta de 3 a 4 semanas, dependendo da alimentação do animal, o retículo-rúmen passa a corresponder a $60 \%$ do total dos quatro compartimentos, enquanto que o abomaso somente a $27 \%$. Um animal com mais de 12 semanas de vida, apresenta o sistema digestivo próprio de um ruminante, sendo o retículo-rúmen $85 \%$ e o abomaso apenas $7 \%$ do total dos quatro compartimentos.

Muitos trabalhos têm mostrado que o desenvolvimento de papilas, responsável pela absorção de produtos finais de fermentação, é dependente da presença de ácidos graxos voláteis (Tamate et al., 1962; Murdock \& Wallenius, 1980; Quigley et al., 1996 a). Dentre os principais AGV produzidos no rúmen, o ácido butírico é o mais importante em relação ao crescimento em número e tamanho de papilas, seguido pelo ácido propiônico; tendo o ácido acético pouca importância. A maior produção desses ácidos graxos voláteis ocorre com a fermentação de alimentos concentrados, com alto teor de carboidratos e proteína. Assim, a disponibilidade de concentrado para o animal desde a primeira semana de vida é indispensável (Anderson et al., 1987 a). 
O consumo de grãos processados, como floculado ou laminado, altera o padrão de fermentação ruminal de forma benéfica ao animal, com maior produção de propionato e consequente maior produção de glicose por gluconeogênese (Theurer et al., 1999). A adição de grão floculado nas dietas de animais de corte em crescimento ou engorda, tem mostrado consistente aumento na eficiência alimentar através da maior utilização de amido quando comparado ao grão não processado ou laminado (Theurer et al., 1996 a).

Dados de desempenho de bezerros em aleitamento recebendo grão processado na mistura concentrada são restritos. Schuh et al. (1970) e Daniels et al. (1972) não observaram efeitos positivos no desempenho ou consumo de concentrado com a inclusão de grãos processados no concentrado de bezerros. Em trabalho subsequente, Schuh et al. (1970 b) observaram maiores ganho de peso diários e consumo de MS em animais recebendo grão floculado. Abdelgadir \& Morrill (1995) compararam concentrado contendo sorgo não processado, tostado ou conglomerado para bezerros em aleitamento. O tipo de processamento não afetou o desempenho, as medidas corporais ou a idade a desmama dos animais. O tipo de processamento também não afetou parâmetros sanguíneos ou ruminais, mas os valores de $\mathrm{pH}$ foram superiores para animais alimentados com sorgo conglomerado.

Os resultados de desempenho obtidos com o fornecimento de ionóforos, como a monensina e a lasalocida, para bezerras leiteiras mostram inconsistência. Stockdale et al. (1982) não observaram diferenças no ganho de peso diário compararam o concentrado controle com o concentrado contendo monensina ou amprolium. Da mesma forma, Foreyt et al. (1986) observaram desempenho similar de bezerros tratados com monensina, lasalocida e decoquinato, um coccidiostático não promotor de crescimento, após inoculação com Eimeria. Outros estudos conduzidos com o fornecimento de lasalocida para animais de diferentes idades, também mostram que a administração do ionóforo não afetou o desempenho de bezerros leiteiros (Stromberg et al., 1982; Hoblet et al., 1989; Heinrichs \& Bush, 
1991; Waggoner et al., 1994). Por outro lado, em alguns trabalhos observou-se melhor desempenho de bezerros recebendo monensina (Fitzgerald \& Mansfield, 1973 e 1984; Watkins et al., 1987) ou lasalocida (Sinks et al., 1992; Quigley, 1996 a). Provavelmente parte da variação nos resultados obtidos se deve a diferentes idades dos animais e ao fato de que animais jovens talvez não utilizem ionóforos como animais adultos o fazem.

O objetivo deste trabalho foi o de avaliar as alterações do fornecimento de grãos processados (laminado a vapor vs. floculado) e monensina em parâmetros ruminais e sanguíneos.

\subsection{Material e métodos}

\subsubsection{Animais e Procedimento Cirúrgico}

Dezesseis machos holandeses foram utilizados em um experimento com delineamento em blocos ao acaso e arranjo fatorial $2 \times 2$. O experimento foi conduzido no Departamento de Produção Animal da Escola Superior de Agricultura "Luiz de Queiroz", da Universidade de São Paulo, em Piracicaba. Os bezerros foram submetidos à cirurgia para colocação de cânula ruminal de látex com orifício de $6 \mathrm{~cm}$, entre 3 e 5 dias após o nascimento.

Após a cirurgia os animais permaneceram em baias coletivas de bezerreiro fechado, de modo a evitar contaminação da região devido ao período chuvoso. Além disso, a permanência nesta instalação facilitou o monitoramento da temperatura corporal e a medicação dos animais. Durante o pós-operatório foram realizados curativos na região da sutura diariamente, com produtos anti-séptico e repelentes; além de aplicação intramuscular de antibiótico à base de penicilina, a cada dois dias. 


\subsubsection{Manejo Alimentar e Dietas Experimentais}

Com a recuperação pós-cirúrgica os animais foram alocados em abrigos individuais, o que permitiu o monitoramento diário do consumo de concentrado e semanal do consumo de feno. Os animais passaram a receber $4 \mathrm{~L}$ de leite por dia, divididos em duas refeições (07 e 18h), além de água à vontade e de uma mistura concentrada. A mistura foi fornecida ad libitum diariamente, após a retirada da sobra do dia anterior, até que o consumo atingisse $2 \mathrm{~kg} / \mathrm{dia}$.

O concentrado, formulado para atender as exigências nutricionais de bezerros até 12 semanas de vida (NRC, 1986), era composto de 67,5\% de milho floculado (F) ou milho laminado (L), $20 \%$ de farelo de soja, $10 \%$ de melaço e 2,5\% de premix de minerais e vitaminas com (LM ou FM) ou sem (L ou F) a adição de monensina (Tabela 1). A concentração de monensina no concentrado foi de 30 ppm, ou $30 \mathrm{mg} / \mathrm{kg}$ de matéria seca dose mais utilizada por produtores por ser recomendada para o controle de coccidiose em bezerros leiteiros. O feno de coastcross passou a ser fornecimento ad libitum, após a desmama dos animais, a qual ocorreu na $8^{\text {a }}$ semana de vida.

Os animais foram pesados ao nascer e a cada semana até completarem 10 semanas de vida, quando se encerrou o período experimental.

Tabela 1. Composição dos alimentos experimentais (\%MS).

\begin{tabular}{llllll}
\hline Ingredientes & $F$ & FM & L & LM & Feno
\end{tabular}




\begin{tabular}{lccccc}
\hline Milho floculado & 67.5 & 67.5 & -- & -- & \\
Milho laminado & -- & -- & 67.5 & 67.5 & \\
Farelo de soja & 20.0 & 20.0 & 20.0 & 20.0 & \\
Melaço & 10.0 & 10.0 & 10.0 & 10.0 & \\
Premix1 & 2.5 & -- & 2.5 & -- & \\
Premix 2 (com monensina) & -- & 2.5 & -- & 2.5 & \\
\% MS & 95,61 & 95,86 & 95,46 & 95,85 & 95,51 \\
\% PB & 17,74 & 17,29 & 17,26 & 18,22 & 7,62 \\
\% Amido & 50,48 & 48,91 & 49,63 & 50,22 & - \\
\% FDN & 6,21 & 5,92 & 7,52 & 8,38 & 69,50 \\
\% FDA & 2,09 & 2,00 & 2,15 & 2,29 & 33,11 \\
$\quad$ \% EE & 2,43 & 2,35 & 2,35 & 2,51 & 0,77 \\
\hline F= milho floculado, FM= milho floculado + monensina, L= milho laminado, LM= milho \\
laminado + monensina.
\end{tabular}

\subsubsection{Consumo de Matéria Seca e Análise Bromatológica}

Para estimar o consumo de matéria seca (MS), amostras dos alimentos foram coletadas e secas à $105^{\circ} \mathrm{C}$, e o teor de MS determinado. Amostras de concentrado e feno fornecidos foram coletadas a cada nova batida, secas à $55^{\circ} \mathrm{Ce}$ moídas à $1 \mathrm{~mm}$ para determinação de $\mathrm{MS}$, matéria orgânica $(\mathrm{MO})$ e proteína bruta (PB) de acordo com AOAC (1980), fibra em detergente neutro (FDN) e fibra em detergente ácido (FDA) pelo método descrito por Van Soest (1991) e amido conforme descrito por Poore (1991).

\subsubsection{Procedimentos de Coleta de sangue e Métodos Analíticos}

4.2.4.1 Metodologia de coleta de sangue para determinação de glicose, N-uréico, 
AGL e $\beta$-hidroxibutirato

Amostras de sangue foram coletadas através de punção da jugular com auxílio de tubos de ensaio a vácuo, contendo $5 \mathrm{mg}$ de fluoreto de sódio como antiglicolítico e $5 \mathrm{mg}$ de oxalato de potássio como anticoagulante para análise de glicose, $\mathrm{N}$-uréico, ácidos graxos livres e $\beta$-hidroxibutirato. As amostragens de sangue foram realizadas a cada 7 dias de vida do animal nos horários $0,2,4,8$ e $12 \mathrm{~h}$ após a alimentação da manhã. As amostras foram centrifugadas a 3000 x g, por 20 minutos, a temperatura de $4{ }^{\circ} \mathrm{C}$ para obtenção do plasma, o qual foi armazenado em tubos de $2 \mathrm{~mL}$ do tipo "eppendorf" a $-10{ }^{\circ} \mathrm{C}$ para posterior análise.

\subsubsection{Determinação de Glicose}

A determinação das concentrações de glicose plasmática foi realizada por leitura direta em autoanalisador YSI 2700 Select (Biochemistry Analyser, Yellow Spring, OH, EUA) no Laboratório de Bromatologia do Departamento de Produção Animal da ESALQ/USP. A leitura direta foi realizada com a utilização de membrana com a enzima glicose oxidase imobilizada. Uma solução de dextrose com concentração de $2 \mathrm{~g} / \mathrm{L}$ foi utilizada como calibrador interno e como solução para controle de qualidade.

\subsubsection{Determinação de N-uréico}

Para as determinações das concentrações de N-uréico no plasma, realizadas no Laboratório de Bromatologia do Departamento de Produção Animal da ESALQ/USP, foi utilizado o método descrito por Chaney e Marbach (1962), adaptado para leitura Leitor de Microplaca (BIO-RAD, Hercules, CA, EUA) 
utilizando-se filtro para absorbância de $550 \mathrm{~nm}$. Foram utilizadas a enzima urease (U-1500, Sigma), e soluções padrões com concentração de $0 ; 3,75 ; 7,5 ; 15$; e $30 \mathrm{mg} / \mathrm{dL}$ de $\mathrm{N}$-uréico. Somente foram aceitos resultados provenientes de placas com $r^{2}=0,99$ e coeficiente de variação entre duplicatas $\leq 5 \%$.

\subsubsection{Determinação de Ácidos Graxos Livres}

As concentrações de ácidos graxos não esterificados no plasma foram determinados enzimaticamente através do kit NEFA-c (Wako Chemicals $\mathrm{GmbH}$, Richmond, VA) sendo o método modificado para leitura em Leitor de Microplaca (BIO-RAD, Hercules, CA, EUA) utilizando-se filtro para absorbância de $550 \mathrm{~nm}$. O padrão de $1 \mathrm{mEq} / \mathrm{L}$ de ácido oléico foi diluído com solução salina $(0,9 \% \mathrm{NaCl})$ nas concentrações de 0; 0,125; 0,5;0,75 e 1,0 mEq/L para obtenção de curva padrão. Cada amostra ou padrão foi então diluído com a solução na concentração de 1:4 (10 $\mu \mathrm{L}: 40 \mu \mathrm{L}$ ), também com a solução salina, através de pipetador automático, diretamente na microplaca. $O$ volume de $50 \mu \mathrm{L}$ do Reagente $\mathrm{A}$ foi adicionado em cada poço da microplaca, a qual foi então agitada e incubada em estufa a $37^{\circ} \mathrm{C}$ durante 10 minutos. Decorrido este período foram então adicionados $100 \mu \mathrm{L}$ do Reagente $B$ sendo a placa agitada novamente e incubada nas mesmas condições. Após 10 minutos a placa foi retirada da estufa, sendo a leitura realizada após 3 minutos. O padrão de $1 \mathrm{mEq} / \mathrm{L}$ de ácido oléico foi utilizado como controle de qualidade da placa. Somente foram aceitos resultados provenientes de placas com $r^{2}=0,99$ e coeficiente de variação entre duplicatas $\leq 5 \%$.

\subsubsection{Determinação de $\beta$-hidroxibutirato}

A determinação de $\beta$-hidroxibutirato foi realizada enzimaticamente através do kit 310-A Sigma (Sigma Diagnostics, St. Louis, MO, EUA), segundo método de 
Williamson et al. (1962), adaptado para leitura em placas de microtítulo em aparelho Microplate Reader BIO RAD (absorbância de $340 \mathrm{~nm}$ ), conforme Grummer (comunicação pessoal). A partir do padrão de $50 \mathrm{mg} / \mathrm{dL}$ foram preparadas soluções com água destilada para obtenção das concentrações 25 , 6,25 , e 3,12 mg/dL para construção de curva de calibração. Uma alíquota de 10 $\mu \mathrm{L}$ de amostra ou solução padrão foi pipetada diretamente na placa, seguida da adição de $300 \mu \mathrm{L}$ do reagente B-HBA e leitura no aparelho (absorbância inicial). Após a adição de $10 \mu \mathrm{L}$ de enzima a placa foi incubada durante 40 minutos a $37^{\circ} \mathrm{C}$, para que a Segunda leitura fosse realizada (absorbância final). A diferença entre as absorbâncias inicial e final foi utilizada para construção de curva de regressão.

\subsubsection{Metodologia de coleta de sangue para determinação de insulina}

Amostras de sangue também foram coletadas através de punção na jugular com tubos de ensaio a vácuo, desprovidos de anticoagulante, para determinação dos níveis de insulina nos mesmos horários após a alimentação da manhã descritos anteriormente. Após a coleta, os tubos foram mantidos em temperatura ambiente para a obtenção do soro, o qual foi armazenado a $-10^{\circ} \mathrm{C}$ em tubos do tipo "ependorf", para posterior análise.

\subsubsection{Determinação de insulina}

As determinações de insulina foram realizadas no Laboratório de Nutrição Animal do Centro de Energia Nuclear na Agricultura (CENA/USP). As concentrações séricas de insulina foram determinadas através da técnica de radioimunoensaio utilizando-se o kit comercial Coat-a-Count (Diagnostics Products Co., Los Angeles, CA, EUA). Somente foram aceitos resultados provenientes de 
ensaios com $r^{2}=0,99$ e coeficiente de variação entre duplicatas $\leq 20 \%$.

\subsubsection{Procedimentos de coleta de conteúdo ruminal e métodos analíticos}

Amostras de conteúdo ruminal foram coletadas a cada 7 dias nos horários 0, 2, 4, 8 e 12h após a alimentação da manhã, até o final do experimento. Nas primeiras semanas de vida dos bezerros, a coleta foi realizada com o auxílio de uma seringa provida de tubo de silicone. Nas semanas mais avançadas, utilizou-se apenas um tubo plástico para a realização da coleta. As amostras, de aproximadamente $50 \mathrm{~mL}$, tiveram o $\mathrm{pH}$ determinado imediatamente após a coleta, através de potenciômetro (DMPH-2, Digimed, Br), sendo armazenadas em seguida à $-10^{\circ} \mathrm{C}$ para posterior análise de ácidos graxos voláteis e amônia.

\subsubsection{Determinação de Amônia Ruminal}

Para determinação de amônia ruminal, as amostras foram descongeladas em temperatura ambiente e centrifugadas a $11.000 \mathrm{~g}\left(4^{\circ} \mathrm{C}\right)$, durante 30 minutos. Uma alíquota de $40 \mu \mathrm{l}$ foi transferida para tubo de ensaio para determinação de amônia em duplicatas pelo método de Chaney \& Marbach (1962) adaptado leitura em Leitor de Microplaca (BIO-RAD, Hercules, CA, EUA) utilizando-se filtro para absorbância de $550 \mathrm{~nm}$. Foram utilizados como padrões soluções de 0; 1; 2; 4; 8; 16; e $32 \mathrm{mg} / \mathrm{dL}$ de amônia. A alíquota de $40 \mu \mathrm{l}$ de amostra ou padrão foi incubada em banho-maria a $37^{\circ} \mathrm{C}$ por 10 minutos, juntamente com $2,5 \mathrm{~mL}$ de reagente fenol e 2,0 mL de reagente hipoclorito. Decorrido o período, as amostras foram pipetadas em microplaca para leitura. Somente foram aceitos resultados

provenientes de placas com $r^{2}=0,99$ e coeficiente de variação entre duplicatas $\leq$ $5 \%$. 
4.2.5.2 Determinação de Ácidos Graxos Voláteis

Para determinação de AGV as amostras sofreram nova centrifugação a $15.000 \mathrm{~g}\left(4^{\circ} \mathrm{C}\right)$, durante 60 minutos, sendo analisadas de acordo com Palmiquist \& Conrad (1971) em cromatógrafo líquido-gasoso (Hewlett Packard 5890 Series II GC), equipado com integrador (Hewlett Packard 3396 Series II Integrator) e injetor automático (Hewlett Packard 6890 Series Injector). O padrão interno utilizado foi o ácido2-metilbutírico sendo acrescentado, em cada tubo para leitura em cromatógrafo, $100 \mu \mathrm{l}$ do padrão, $800 \mu \mathrm{l}$ da amostra e $200 \mu \mathrm{l}$ de ácido metafosfórico. Uma mistura de ácidos graxos voláteis com concentração conhecida foi utilizada como padrão externo para a calibração do integrador.

\subsubsection{Abate Animal e Medidas morfométricas do Trato Digestivo.}

Ao final do experimento, que ocorreu a 10 semana de vida, os animais foram pesados e em seguida abatidos. $\mathrm{O}$ abate dos animais foi realizado por meio de atordoamento e sangria, com o corte da jugular. Os animais tiveram a cavidade abdominal aberta sendo os quatro compartimentos retirados livres de tecido adiposo omental. O conteúdo do trato foi retirado com auxílio de lavagens com água. Os compartimentos foram divididos em retículo-rúmen, omaso e abomaso. A capacidade máxima do retículo-rúmen foi medida com auxílio de amarrações na saída deste compartimento, sendo este cheio com água até sua máxima capacidade. $\mathrm{O}$ volume utilizado foi medido em proveta de vidro. Após retirada do excesso de água dos tecidos, foram tomadas medidas de peso do retículo-rúmen, do omaso, do abomaso e dos 4 compartimentos em conjunto.

\subsubsection{Análise Estatística}

Os dados apresentados de consumo de MS, peso e ganho de peso foram 
analisados através do PROC MIXED do pacote SAS (1991), utilizando-se o peso ao nascer como covariável. Os dados de parâmetros sanguíneos e ruminais também foram analisados a partir do PROC MIXED do pacote SAS (1991), levando em conta os efeitos hora e semana de colheita de amostra.

\subsection{Resultados e discussão}

O consumo de concentrado não foi afetado $(P>0,05)$ pelo tipo de grão ou inclusão de monensina. Como pode ser observado na Tabela 2, o consumo de concentrado foi inferior ao esperado provavelmente devido ao efeito da cirurgia para implantação das cânulas ruminais. O consumo na oitava semana, quando ocorreu a desmama, esteve abaixo do recomendado por Quigley (1996) para garantir um mínimo desenvolvimento ruminal e a realização da desmama com propriedade.

Tabela 2. Médias dos quadrados mínimos do consumo de concentrado (g $\mathrm{MS} / \mathrm{d})$.

\begin{tabular}{lllllll} 
Semana & $F^{1}$ & FM & $L$ & LM & EPM $^{2}$ & Subparcela $^{3}$ \\
\hline
\end{tabular}




\begin{tabular}{ccccccc}
\hline 2 & 45,38 & 53,29 & 0 & 45,80 & 103,71 & 33,19 \\
3 & 38,95 & 66,87 & 17,96 & 80,42 & 100,17 & 51,05 \\
4 & 31,45 & 62,85 & 50,49 & 125,25 & 100,17 & 67,51 \\
5 & 58,98 & 75,32 & 79,50 & 178,64 & 101,36 & 98,11 \\
6 & 27,37 & 98,57 & 126,91 & 170,07 & 102,17 & 105,73 \\
7 & 58,94 & 75,34 & 102,45 & 184,17 & 103,79 & 105,23 \\
8 & 106,95 & 53,68 & 196,91 & 149,53 & 104,91 & 126,77 \\
9 & 114,71 & 70,92 & 222,66 & 266,49 & 107,79 & 168,70 \\
10 & 134,91 & 75,13 & 208,64 & 383,28 & 109,71 & 200,49 \\
\hline
\end{tabular}

${ }^{1} \mathrm{~F}=$ milho floculado, $\mathrm{FM}=$ milho floculado + monensina, $\mathrm{L}=$ milho laminado, $\mathrm{LM}=$ milho laminado + monensina.

${ }^{2}$ Erro padrão da média.

${ }^{3}$ Subparcela, produção média de todos os tratamentos.

O consumo de feno, fornecido após a desmama, também não foi afetado pelos tratamentos, mas foi superior ao consumo de concentrado, fato que não é esperado para esta fase da vida do animal. Este resultado não foi observado no capítulo, no experimento com fêmeas leiteiras.

Tabela 3. Médias dos quadrados mínimos do consumo de feno (g MS/d).

\begin{tabular}{ccccccc}
\hline Semana & $F^{1}$ & FM & L & LM & EPM $^{2}$ & Subparcela $^{3}$ \\
\hline Sem 9 & 393,73 & 24,31 & 341,80 & 445,48 & 300,86 & 301,33 \\
Sem 10 & 405,40 & 74,31 & 368,47 & 887,98 & 300,86 & 431,54 \\
\hline
\end{tabular}

${ }^{1} \mathrm{~F}=$ milho floculado, $\mathrm{FM}=$ milho floculado + monensina, $\mathrm{L}=$ milho laminado, $\mathrm{LM}=$ milho laminado + monensina.

${ }^{2}$ Erro padrão da média.

${ }^{3}$ Subparcela, produção média de todos os tratamentos.

Como pode ser observado na Figura 1, os baixos consumos de concentrado resultaram em desempenho inferior ao recomendado em literatura (Hoffman, 1997), e perda de peso após a desmama. 


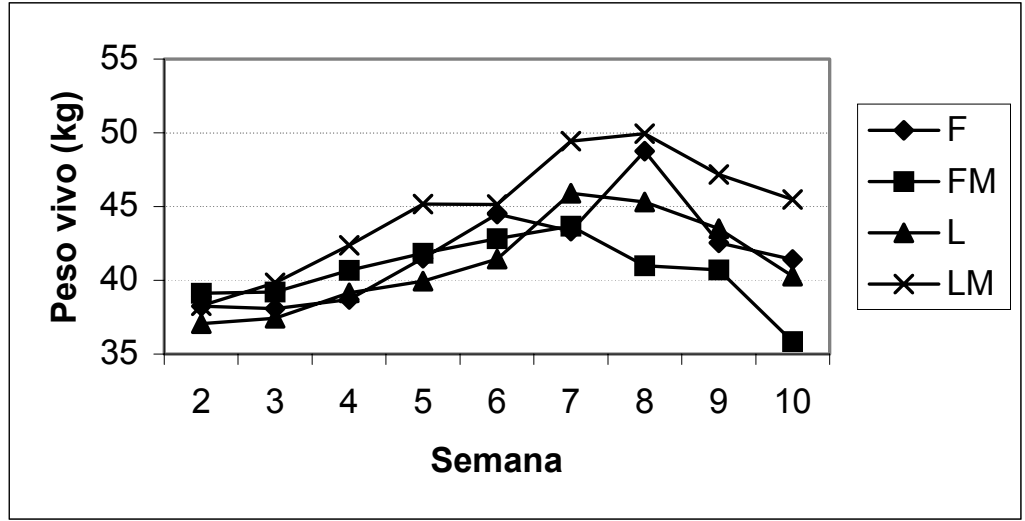

Figura 1 - Peso vivo animal durante o período experimental $(\mathrm{kg})$

Tabela 4. Médias dos quadrados mínimos de parâmetros ruminais.

\begin{tabular}{|c|c|c|c|c|c|c|c|c|}
\hline & \multicolumn{4}{|c|}{ Tratamentos } & & \multicolumn{3}{|c|}{$P$} \\
\hline & $F^{1}$ & FM & $\mathrm{L}$ & LM & $\mathrm{EPM}^{2}$ & $\mathrm{G}^{3}$ & M & GxM \\
\hline $\mathrm{PH}$ & 6,67 & 6,86 & 6,68 & 6,73 & 0,25 & 0,81 & 0,63 & 0,79 \\
\hline AGV total, $\mathrm{mM}$ & 56,88 & 32,19 & 62,79 & 66,56 & 11,67 & 0,11 & 0,38 & 0,24 \\
\hline Acético, mM & 32,57 & 16,54 & 28,71 & 35,64 & 6,69 & 0,29 & 0,52 & 0,12 \\
\hline Propiônico, mM & 16,97 & 10,47 & 25,03 & 21,66 & 4,03 & 0,03 & 0,24 & 0,70 \\
\hline Butírico, mM & 4,70 & 3,04 & 5,45 & 5,57 & 1,01 & 0,13 & 0,46 & 0,39 \\
\hline Acético:propiônico & 1,91 & 2,07 & 1,76 & 1,84 & 0,26 & 0,90 & 0,65 & 0,88 \\
\hline Amônia, mg/dL & 13,85 & 8,96 & 12,99 & 12,77 & 1,53 & 0,35 & 0,12 & 0,15 \\
\hline
\end{tabular}

A tabela 4 apresenta as médias dos quadrados mínimos de parâmetros ruminais durante todo o período experimental.

Não foram observados efeitos significativos dos tratamentos no $\mathrm{pH}$ ruminal médio. Greenwood et al. (1997b) também não observaram efeito do 
processamento físico de concentrado de bezerros jovens nos valores de $\mathrm{pH}$ do fluido ruminal. Vários trabalhos têm demonstrado queda no $\mathrm{pH}$ ruminal com o fornecimento de grãos com alta degradabilidade ruminal, como é o caso de milho floculado para novilhas de corte e vacas leiteiras (Theurer, 1986). Beharka et al. (1998) observaram menores valores de $\mathrm{pH}$ com o fornecimento de dieta moída para bezerros em aleitamento. Quigley et al. (1992) observou maiores valores de $\mathrm{pH}$ com o fornecimento de lasalocida para bezerros antes ou após a desmama. Os autores sugerem que este efeito se deve à inibição de bactérias ruminais nas primeiras semanas de vida, como foi observado por Anderson et al. (1988). Nagaraja et al. (1981) observaram maior pH ruminal em vacas recebendo monensina, quando tentou-se simular acidose com infusão ruminal de glicose ou milho finamente moído.

A concentração de ácidos graxos voláteis total não foi alterada $(P>0,05)$ pelos tratamentos de forma significativa (Tabela 4). Como consequência dos baixos níveis de consumo de concentrado, as concentrações de AGV totais foram menores que as observadas por Winter (1985), Quigley et al. (1992) e Greenwood et al. (1997). Houve tendência para efeito do processamento de grãos $(P=0,11)$, sendo as concentrações molares de AGV total superiores em animais recebendo concentrado com grão laminado. Esta tendência não era esperada uma vez que a digestibilidade ruminal de grãos floculados é superior (Theurer et al., 1999). Por outro lado, as menores proporções molares podem significar uma maior taxa de absorção e não menor produção de AGV (Beharka et al., 1998). Embora não tenham ocorrido diferenças no $\mathrm{pH}$ ruminal, estes dados podem estar indicando maior desenvolvimento do rúmen e portanto maior capacidade de absorção em animais recebendo grãos floculados. Sutton et al. (1963) observaram aumentos na taxa de absorção de AGV de bezerros recebendo grãos a partir da 4 a semana de vida, sendo a taxa máxima observada na $13^{\text {a }}$ semana.

Houve tendência $(P=0,12)$ para a interação entre processamento de milho e monensina na concentração molar de ácido acético (Tabela 4). Quigley et al. 
(1992) não observaram efeito do fornecimento de lasalocida na concentração molar deste ácido. Greenwood et al. (1997) também não observaram efeito quando forneceram concentrado com maior ou menor nível de processamento físico. Assim, este efeito ocorreu supostamente devido ao maior consumo de feno observado e não devido ao efeito da fermentação do grão na presença de monensina. A concentração de AGV no fluido ruminal é diferente para alimentos volumosos e concentrados (Owens \& Goetsch, 1988). Rogers \& Davis (1982) observaram aumento na produção de ácido acético com a inclusão de monensina na dieta de novilhos alimentados com dieta contendo $50 \%$ de concentrado e $50 \%$ de volumoso.

Contrariando as expectativas, animais alimentados com grãos floculados apresentaram menores proporções molares de ácido propiônico $(P<0,05)$ (Tabela 4). Vários trabalhos demonstraram aumento na concentração de ácido propiônico com a inclusão de grão com alta digestibilidade de amido no rúmen na dieta de bovinos (Theurer et al., 1986). Esperava-se a interação tipo de processamento de grão e inclusão de monensina resultando em maiores proporções molares de ácido propiônico para o tratamento FM. A monensina e a lasalocida têm, reconhecidamente, o efeito de aumentar tanto a taxa de produção, quanto a concentração molar de ácido propiônico (McGuffey e al., 2001). Entretanto, este efeito também não foi observado no trabalho de Quigley et al. (1992) com o fornecimento de lasalocida para bezerros antes e após a desmama.

A relação acetato:propionato não foi alterada $(P>0,05)$ pelos tratamentos. De maneira geral, tanto a inclusão de monensina quanto o fornecimento de grão floculado reduzem a relação acético:propiônico, principalmente devido ao aumento na concentração de ácido propiônico (Theurer et al., 1986; McGuffey e al., 2001). Quigley et al. (1992) observaram redução nesta relação com o fornecimento de lasalocida para bezerros em aleitamento, embora as proporções molares dos ácidos acético e propiônico não tenham sido diferentes do controle.

Houve tendência do tipo de processamento na concentração molar de ácido 
butírico ( $P=0,13)$, de forma que os animais recebendo grão laminado apresentaram os maiores valores (Tabela 4). Greenwood et al. (1997) não observaram efeito do processamento físico de concentrado na concentração molar de ácido butírico. Conforme demonstraram inúmeros trabalhos, o principal estímulo para o desenvolvimento do rúmen é a presença de AGV neste compartimento, em especial o ácido butírico (Tamate et al., 1962; Sakata \& Tamate, 1978; Murdock \& Wallenius, 1980; Quigley et al., 1996). A maior concentração molar deste ácido resultante do fornecimento de grãos laminados pode levar a melhor desenvolvimento ruminal e garantia de desmama adequada. Quigley et al. (1992) observaram uma tendência para menores proporções molares de ácido butírico em animais recebendo lasalocida, o que seria um fator limitante para a inclusão de ionóforos em concentrado de bezerros antes da desmama.

Pode-se observar uma tendência de inclusão de monensina $(P=0,12)$ e de interação tipo de processamento de grão e inclusão de monensina $(P=0,15)$ nos níveis médios de amônia ruminal (Tabela 4). A concentração de amônia ruminal foi reduzida com o fornecimento de monensina conforme observado em outros trabalhos (Whetstone et al., 1981; Chen \& Russell, 1991). A redução na produção de amônia está relacionada a redução na população de bactérias que deaminam aminoácidos (Yang \& Russel, 1993, citados por McGuffey et al., 2001).

Trabalhos avaliando grãos processados também observaram redução nos níveis de amônia ruminal com grão floculado, sugerindo maior síntese de proteína microbiana (Plascencia \& Zinn, 1996; Poore et al., 1993; Santos, 1998). No presente estudo, a floculação não reduziu a concentração ruminal de $\mathrm{N}-\mathrm{NH}_{3}$.

Foram observados efeitos significativos da idade (semana) e hora após o fornecimento de alimento em vários parâmetros ruminais como mostram as Figuras 2 a 7. 

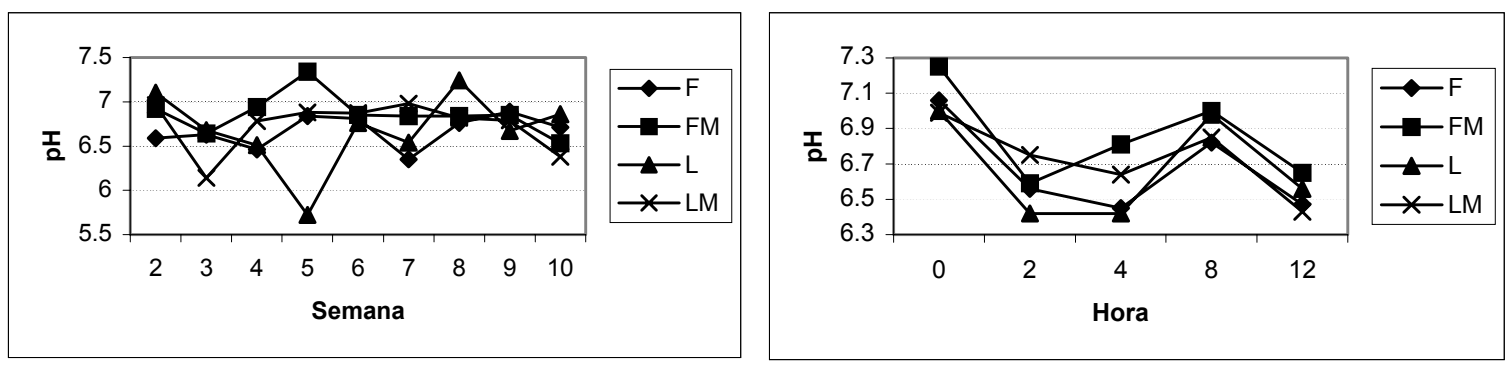

Figura 2 - Médias do quadrados mínimos do valores de $\mathrm{pH}$ ruminal com a idade do animal e horário após o fornecimento.
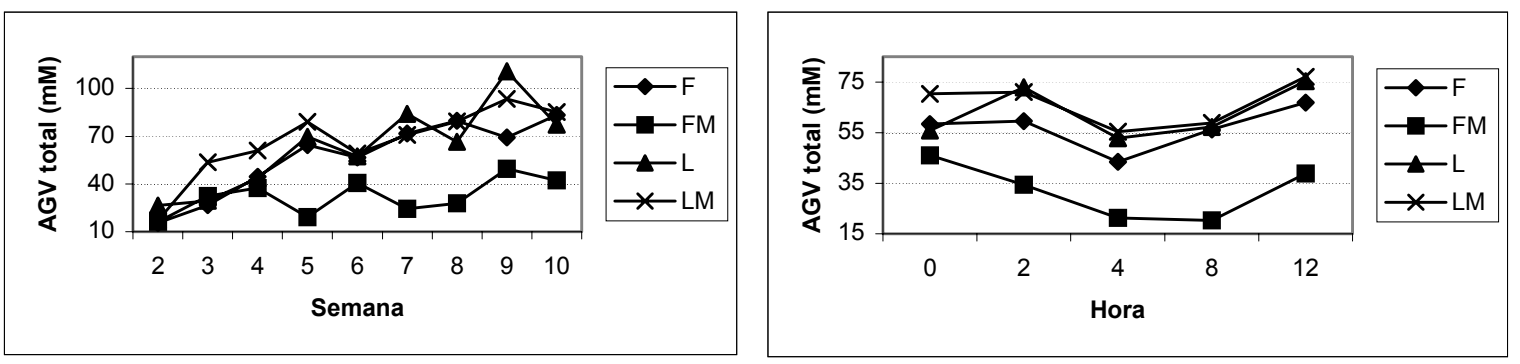

Figura 3 - Médias do quadrados mínimos das proporções molares de ácidos graxos voláteis totais com a idade do animal e horário após o fornecimento.
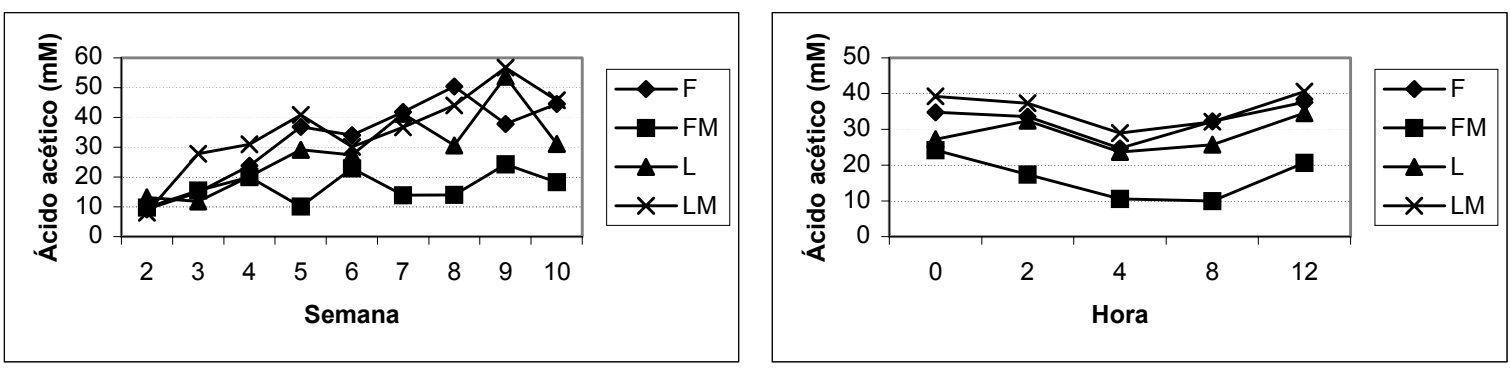

Figura 4 - Médias do quadrados mínimos das proporções molares de ácido acético com a idade do animal e horário após o fornecimento. 

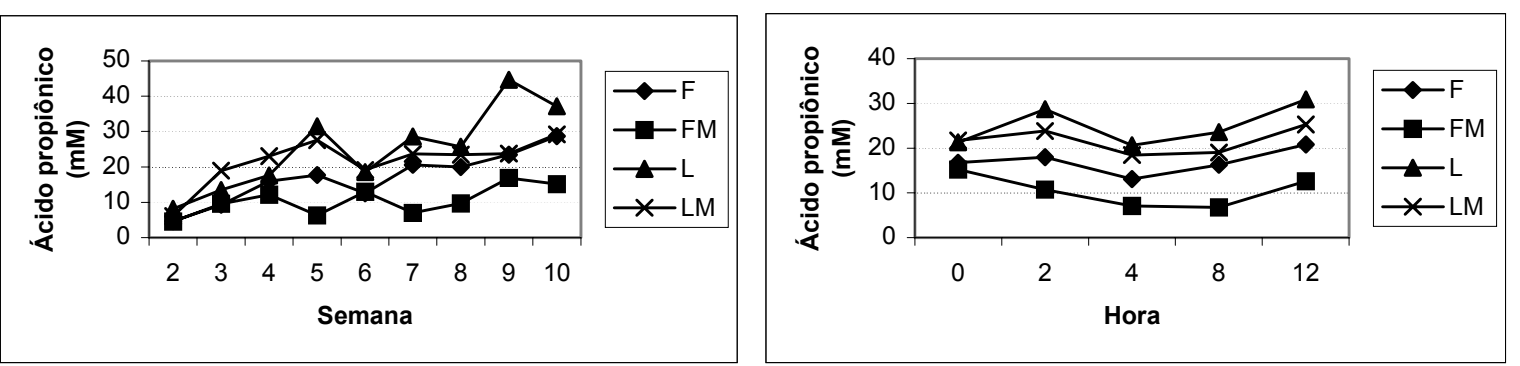

Figura 5 - Médias do quadrados mínimos das proporções molares de ácido propiônico com a idade do animal e horário após o fornecimento.
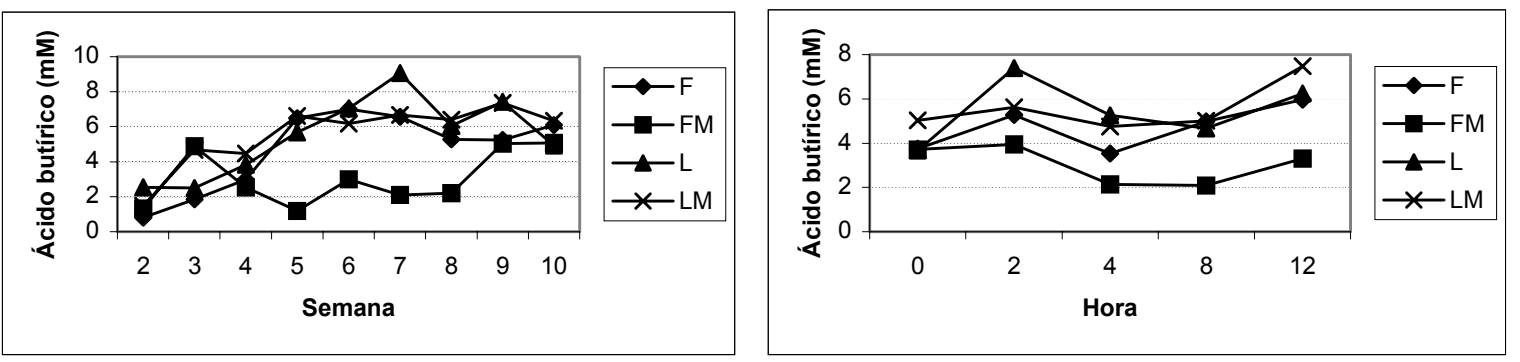

Figura 6 - Médias do quadrados mínimos das proporções molares de ácido butírico com a idade do animal e horário após o fornecimento.
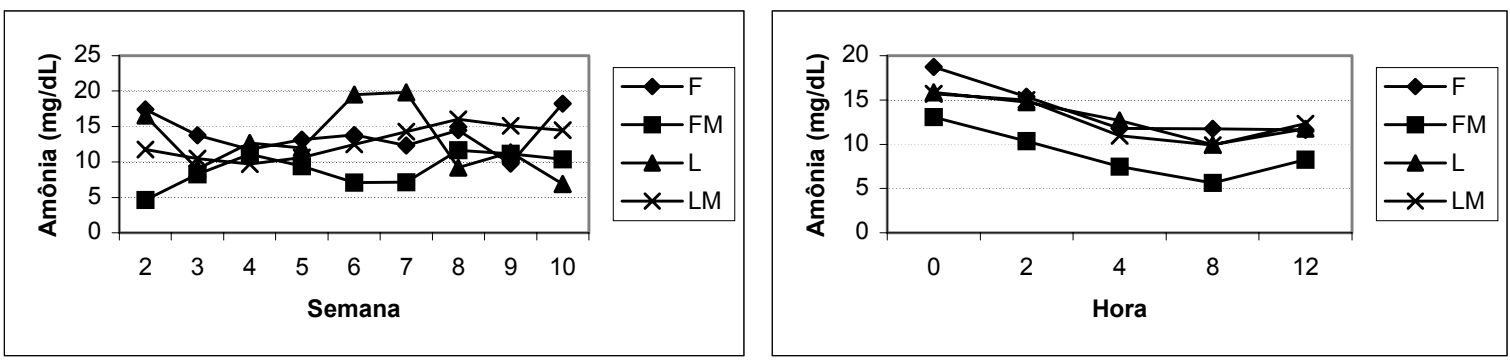

Figura 7 - Médias do quadrados mínimos das concentrações ruminais de amônia com a idade do animal e horário após o fornecimento.

Observou-se efeito significativo de semana de vida e hora após o fornecimento de alimento $(\mathrm{P}<0,05)$ nos valores de $\mathrm{pH}$ no fluido ruminal, como pode ser observado nas Figuras 2 e 3 . Houve um pequeno decréscimo nos valores de 
pH com o avanço da idade do animal, conforme observado por Anderson et al. (1987b). Os valores de $\mathrm{pH}$ ruminal estão dentro da faixa aceitável para manutenção da saúde ruminal e fermentação adequada (Van Soest, 1994). O trabalho de Beharka et al. (1998) demonstrou redução no pH ruminal após a segunda semana e aumento após a décima semana de vida. Estes autores observaram alta influência da forma física do concentrado no $\mathrm{pH}$, sendo superior para animais recebendo dieta não moída, ou seja, sem processamento físico. Greenwood et al. (1997) também observaram efeito da forma física no pH ruminal, sendo estes valores maiores em bezerros alimentados com dieta grosseira.

Os menores valores de $\mathrm{pH}$ ruminal foram observados 2 a 4 horas após o fornecimento do alimento, assim como no trabalho de Anderson et al. (1987a). Estes dados sugerem rápida fermentação ruminal e consequente produção de ácidos graxos voláteis.

Embora não tenha ocorrido aumento significativo no consumo de concentrado com o avanço da idade do animal, houve efeito significativo da idade do animal (semana) na concentração molar de AGV total $(P<0,01)$ (Figura 3); fato também observado em outros trabalhos (Quigley et al., 1985; Anderson et al., 1987 a; Klein et al., 1987; Beharka et al., 1998). Este aumento se deve ao aumento na capacidade de fermentação de alimentos observado com o avanço da idade de bezerros recebendo grãos, e conseqüente desenvolvimento ruminal. A Figura 3 também mostra o efeito significativo da interação semana e monensina $(P=0,032)$.

Houve efeito significativo do horário após o fornecimento de alimento nas proporções molares de AGV $(P<0,01)$, sendo os menores valores observados por volta de 4 horas após o fornecimento. Este padrão pode ter ocorrido devido a diferente taxa de absorção e metabolismo de AGV na parede ruminal, uma vez que de 2 a 4 horas observou-se menores valores de pH (Figura 2).

A concentração dos ácidos acético, propiônico e butírico sofreram efeitos significativos dos fatores idade do animal $(P<0,01)$ e hora após o fornecimento do 
alimento $(P<0,01)$. As proporções molares de ácido acético sofreram ainda efeitos das interações idade e tipo de processamento de grãos $(P=0,048)$, idade e inclusão de monensina $(P=0,025)$, e da interação tríplice idade do animal, tipo de grão e inclusão de monensina $(P=0,007)$. Por outro lado, as proporções molares dos ácidos propiônico e butírico sofreram efeito da interação idade do animal e inclusão de monensina $(P<0,05)$.

De maneira geral, as proporções molares de cada um dos ácidos graxos voláteis foi aumentada com o avanço da idade do animal (Figura 4, 5 e 6), demonstrando aumento na fermentação ruminal. Anderson et al. (1987b) também observaram aumento nas proporções molares dos ácidos graxos voláteis no rúmen de bezerros com o rúmen em desenvolvimento.

As menores proporções molares destes ácidos foram observadas de 4 a horas após o fornecimento do alimento (Figura 4, 5 e 6), sugerindo absorção destes produtos de fermentação através da parede ruminal, uma vez que estes período se sucedeu ao período de menores valores de $\mathrm{pH}$.

Os níveis de amônia ruminal não foram afetados pela idade do animal, entretanto observou-se efeito da interação idade do animal com o tipo de grão $(P=0,0023)$ ou com a inclusão de monensina $(P=0,0006)$, o que resultou em tendência $(P<0,06)$ de efeito da interação idade do animal, tipo de grão e inclusão de monensina. As concentrações de amônia ruminal foram alteradas com a idade do animal no trabalho de Anderson et al. (1987b), independentemente da idade de desmama.

Tabela 5. Médias dos quadrados mínimos de parâmetros sanguíneos.

\begin{tabular}{|c|c|c|c|c|c|c|c|c|}
\hline & \multicolumn{4}{|c|}{ Tratamentos } & \multicolumn{4}{|c|}{$P$} \\
\hline & $F^{1}$ & FM & $\mathrm{L}$ & LM & $\mathrm{EPM}^{2}$ & $\mathrm{G}^{3}$ & M & GxM \\
\hline Glicose, mg/dL & 68,55 & 71,79 & 69,10 & 65,62 & 2,21 & 0,23 & 0,95 & 0,15 \\
\hline Insulina & 4,14 & 4,92 & 4,38 & 3,79 & 0,50 & 0,39 & 0,85 & 0,20 \\
\hline
\end{tabular}


N-uréico, mg/dL $\quad 13,56 \quad 12,09 \quad 16,62 \quad 12,34 \quad 3,01 \quad 0,59 \quad 0,35 \quad 0,64$

AGL, $\quad \begin{array}{llllllll}275,48 & 292,82 & 266,23 & 247,15 & 23,06 & 0,25 & 0,97 & 0,44\end{array}$

$\begin{array}{lllllllll}\text { BHBA } & 7,74 & 6,62 & 5,75 & 4,82 & 0,99 & 0,08 & 0,32 & 0,92\end{array}$

${ }^{1} \mathrm{~F}=$ milho floculado, $\mathrm{FM}=$ milho floculado + monensina, $\mathrm{L}=$ milho laminado, $\mathrm{LM}=$ milho laminado + monensina.

${ }^{2}$ Erro padrão da média.

${ }^{3} \mathrm{G}=$ efeito do processamento de grão, $M=$ efeito da adição de monensina, $G \times M=$ interação de processamento de grão e monensina.

Não houve efeito na concentração de glicose plsmática $(P>0,05)$. Os dados de literatura são consistentes quanto à maior produção de propionato no rúmen com o fornecimento de grãos floculados e monensina, o que pode resultar em maiores níveis de glicose plasmática devido a maior produção hepática (gluconeogênese) (Theurer et al., 1999; Sauer et al., 1989). Entretanto, como observado por Quigley et al. (1992) o efeito observado com o fornecimento de ionóforos deve ocorrer somente após a desmama, quando o animal já apresenta o rúmen parcialmente desenvolvido. Greenwood et al. (1997) não observou efeitos nas proporções molares de ácido propiônico ou nas concentrações plasmáticas de glicose comparando concentrados com diferente tamanho de partícula, sugerindo que estes efeitos devam ser mais marcantes em bezerros com o rúmen funcional.

Os tratamentos não alteraram $(P>0,05)$ as concentrações de insulina plasmática. Trabalhos pioneiros sobre a proliferação de células do epitélio ruminal demonstraram que a insulina é o hormônio estimulado pelo ácido butírico no rúmen (Sakata \& Tamate, 1978; Jordan \& Phillips, 1978; Sakata et al., 1980). A não observação de efeitos significativos na produção de butirato pode ter reduzido a oportunidade de se observar efeitos nos níveis de insulina. Adicionalmente, o nível de glicose no sangue determina o fluxo através da glicólise, ciclo de Krebs e consequente geração de ATP, o grande sinalizador para a síntese e secreção de insulina (Mayes, 1993). Dessa forma, a concentração de insulina deve ser paralela àquela de glicose, como foi observado neste trabalho. 
Não foram observadas diferenças entre os tratamentos $(P>0,05)$ para concentrações de N-uréico no plasma (Tabela 5). Em experimento semelhante Nussio (2002) observou forte tendência para menor $\mathrm{N}$-uréico no plasma de bezerros alimentados com grão laminado e monensina. Eicher-Pruiett et al. (1992) observaram redução nos níveis plasmáticos de $\mathrm{N}$-uréico com o fornecimento de lasalocida. Uma vez que estes níveis estão fortemente correlacionados com o consumo de concentrado (Quigley \& Bernard, 1992), a inclusão de ionóforos no concentrado deve reduzir estes níveis, já que geralmente deprime consumo de alimento. Greenwood et al. (1997) não observou diferenças nos níveis de N-uréico quando comparou diferentes tipos de processamento de grãos para bezerros em aleitamento.

As concentrações de $\mathrm{N}$-uréico podem refletir os níveis de amônia ruminal. Entretanto, as diferenças observadas nas concentrações de amônia ruminal não influenciaram os níveis de $\mathrm{N}$-uréico no plasma dos animais.

As concentrações plasmáticas de AGL também não foram afetadas $(P>0,05)$ pelos tratamentos (Tabela 5). Esse fato está de acordo as concentrações de glicose e insulina plasmáticas, as quais não foram afetadas pelos tratamentos. Quigley et al. (1992 a) observou redução nos níveis de AGL após a desmama em bezerros recebendo monensina. As concentrações observadas podem refletir o baixo consumo de concentrado e possível mobilização de reserva corporal desses animais, explicado pelo baixo ganho de peso antes e perda de peso após a desmama.

As concentrações de BHBA foram menores $(\mathrm{P}=0,08)$ no plasma bezerros recebendo grão laminado (Tabela 5). Quigley et al. (1992) observaram aumento nos níveis de BHBA com o fornecimento de lasalocida e sua alta correlação com consumo de matéria seca, sugerindo a formação deste a partir de produtos finais de fermentação. Segundo os autores, os níveis de BHBA no plasma devem refletir as proporções molares de ácido butírico, o que não foi observado neste trabalho. Embora os níveis de glicose estejam situados dentro da amplitude esperada, os 
altos níveis de BHBA e de AGL sugerem que a principal fonte de corpos cetônicos neste trabalho é proveniente de cetogênese hepática.

As médias dos quadrados mínimos de parâmetros sanguíneos de acordo coma idade do animal e a hora após o fornecimento de alimento estão representada nas Figuras 8 a 12. Foram observados efeitos significativos da idade (semana) $(P<0,01)$ em todos os parâmetros sanguíneos excetuando-se os níveis de BHBA $(P>0,05)$. O efeito hora após o fornecimento de alimento afetou parâmetros sanguíneos $(P<0,01)$, exceto as concentrações de $N$-uréico no plasma.
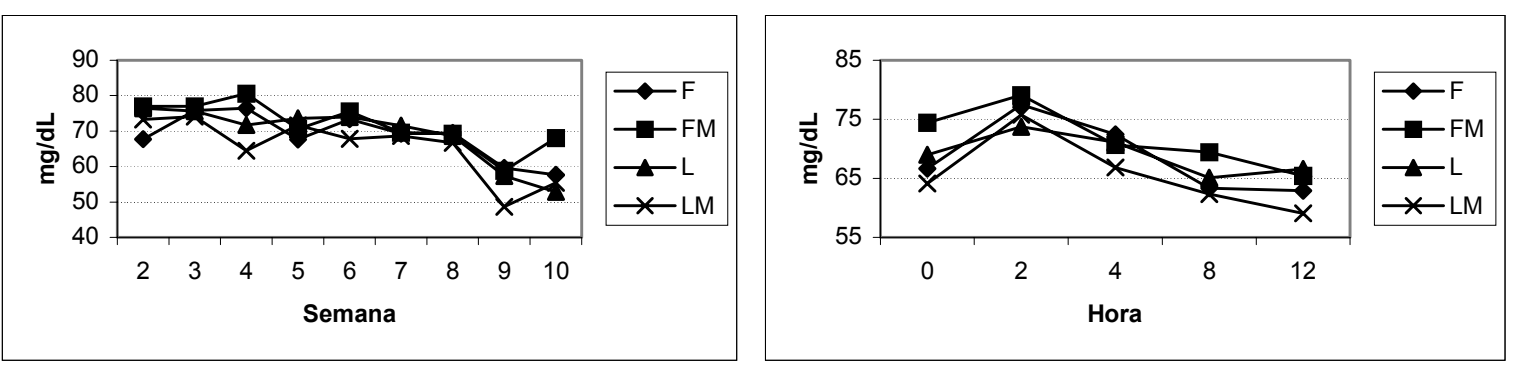

Figura 8 - Médias do quadrados mínimos das concentrações plasmáticas de glicose com a idade do animal e horário após o fornecimento.
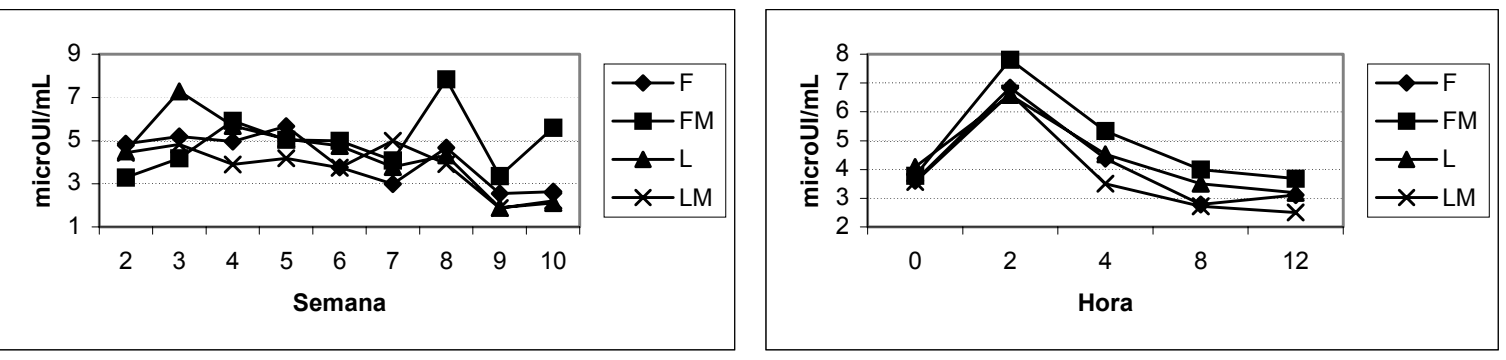

Figura 9 - Médias do quadrados mínimos das concentrações séricas de insulina com a idade do animal e horário após o fornecimento. 

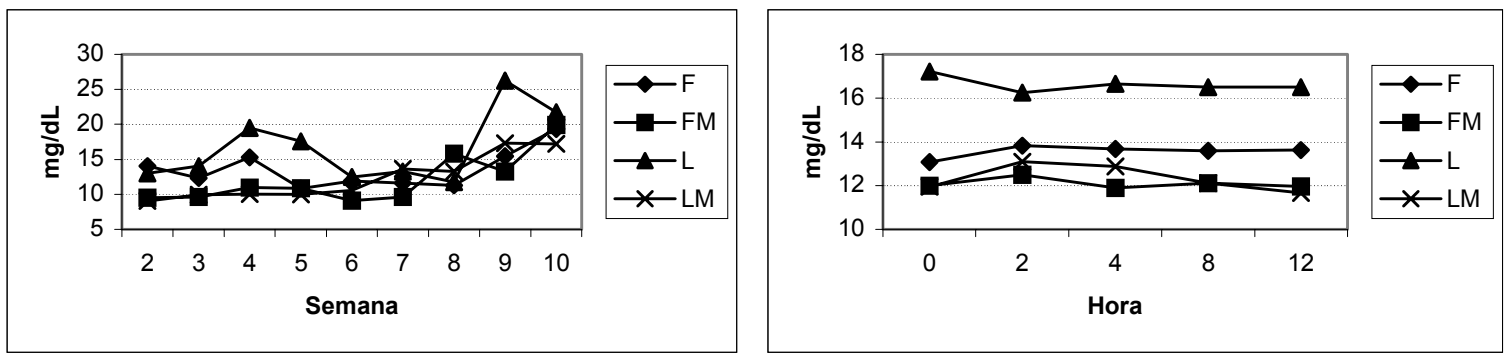

Figura 10 - Médias do quadrados mínimos das concentrações plasmáticas de Nuréico com a idade do animal e horário após o fornecimento.
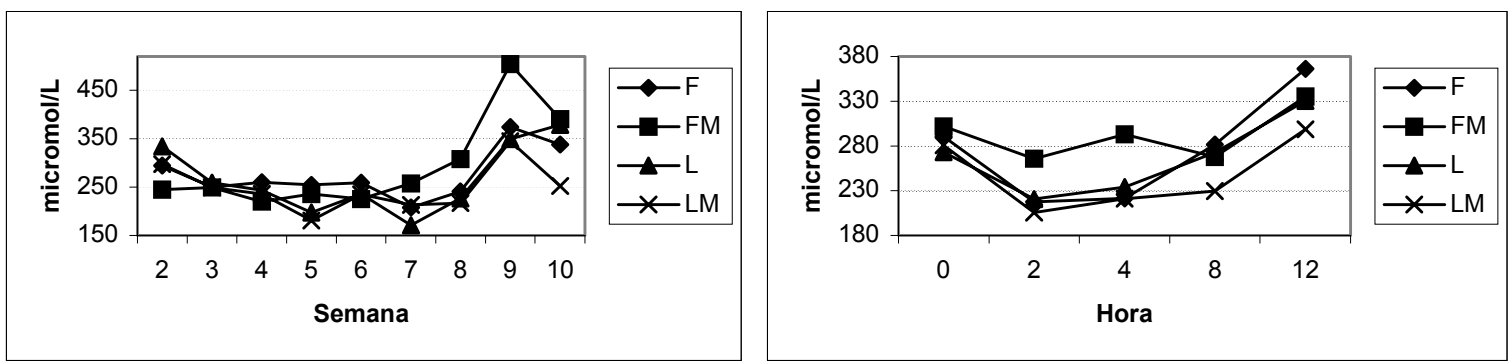

Figura 11 - Médias do quadrados mínimos das concentrações plasmáticas de AGL com a idade do animal e horário após o fornecimento.
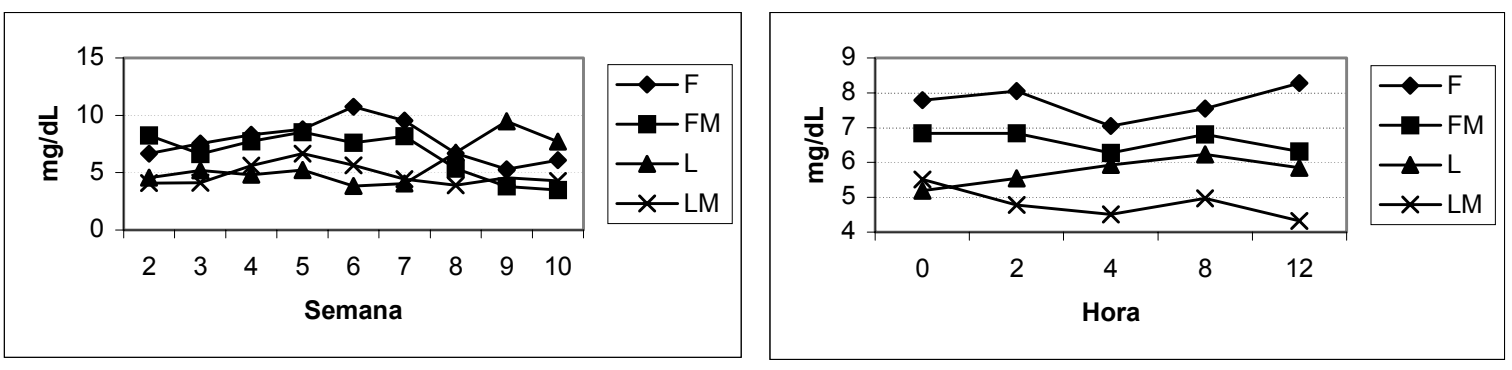

Figura 12 - Médias do quadrados mínimos das concentrações plasmáticas de BHBA com a idade do animal e horário após o fornecimento. 
As concentrações plasmáticas de glicose foram reduzidas com o avanço da idade após a desmama, assim como observado por outros autores (Quigley et al., 1991; Greenwood et al., 1997; Williams et al., 2001). Ao contrário, as concentrações de AGL e N-uréico foram constantes antes, mas aumentaram após a desmama. Quigley et al. (1992 a) observou redução de AGL antes da desmama e manutenção dos níveis após a desmama de bezerros leiteiros. Como discutido anteriormente o aumento dos níveis de AGL sugere a mobilização de reserva corporal, principalmente após a desmama, quando a quantidade de nutrientes fornecida foi reduzida com a retirada do leite da dieta dos animais. Entretanto, não foi possível observar esta tendência nas concentrações de BHBA.

Quigley et al. (1992 a) e Greenwood et al. (1997) observaram aumento na concentração de BHBA no plasma de bezerros com o avanço da idade devido ao aumento no metabolismo na parede ruminal, em consequência do desenvolvimento deste compartimento. As concentrações plasmáticas de BHBA podem refletir o aumento na concentração de butirato no rúmen como observado por Greenwood et al. (1997). Neste trabalho, devido ao baixo consumo de matéria seca esta tendência não pode ser observada. Os maiores picos de glicose foram observados 2 horas após o fornecimento de alimento, sugerindo rápida fermentação do alimento, como também observado em outros trabalhos (Quigley et al., 1991 a; Quigley \& Bernard, 1992). O pico de insulina também ocorreu 2 horas após o fornecimento de alimento, demonstrando o efeito regulador de glicose na secreção deste hormônio.

Segundo Trenkle \& Kuhlmeier (1996) existe uma relação negativa entre as concentrações de AGL e glicose após a alimentação de bezerros, devido a sensibilidade dos níveis de AGL às concentrações de glicose e produtos de fermentação ruminal. As Figuras 8 e 11 mostram que este padrão de comportamento também foi observado neste trabalho, assim como observado no capítulo 3, no trabalho com fêmeas leiteiras.

As concentrações de $\mathrm{N}$-uréico e BHBA não foram afetadas pelo horário 
após a alimentação dos animais. Quigley et al. (1992 b) observaram pico na concentração de BHBA 4 horas após o fornecimento da dieta, associado ao comportamento de ácido butírico.

A Tabela 6 apresenta os resultados das medidas de peso do trato digestivo superior e de seus quatro compartimentos.

Não houve efeito significativo do processamento de grãos, inclusão de monensina ou da interação destes dois fatores no peso do trato total, em gramas ou quando expresso em porcentagem do peso vivo do animal. Os valores observados são comparáveis aos encontrados por Tamate et al. (1962) em bezerros de 4 semanas de vida alimentados com leite, grãos e feno.

Tabela 6. Medidas métricas dos compartimentos ruminais.

\begin{tabular}{ccccccccc}
\hline & \multicolumn{4}{c}{ Tratamentos } & & \multicolumn{3}{c}{$\mathrm{P}$} \\
\cline { 2 - 3 } & $\mathrm{F}^{1}$ & $\mathrm{FM}$ & $\mathrm{L}$ & $\mathrm{LM}$ & $\mathrm{EPM}^{2}$ & $\mathrm{G}^{3}$ & $\mathrm{M}$ & $\mathrm{GxM}$ \\
\hline Trato Total, g & 813,33 & 708,33 & 845,00 & 1027,50 & 161,08 & 0,30 & 0,81 & 0,39 \\
\% PV & 1,89 & 1,77 & 2,07 & 2,17 & 0,30 & 0,36 & 0,98 & 0,72 \\
Retículo-rúmen, g & 503,33 & 433,33 & 520,00 & 705,00 & 116,15 & 0,24 & 0,63 & 0,29 \\
\% Trato total & 61,43 & 61,01 & 61,20 & 67,49 & 1,80 & 0,11 & 0,13 & 0,09 \\
Capacidade, L & 9,68 & 5,96 & 7,65 & 12,37 & 1,79 & 0,25 & 0,78 & 0,04 \\
Omaso, g & 100,00 & 81,66 & 106,25 & 118,75 & 21,03 & 0,33 & 0,89 & 0,48 \\
\% Trato total & 12,37 & 11,46 & 12,54 & 11,56 & 0,69 & 0,85 & 0,20 & 0,96 \\
Abomaso, g & 221,66 & 195,00 & 212,50 & 210,00 & 29,42 & 0,92 & 0,63 & 0,69 \\
\% Trato total & 27,43 & 27,88 & 25,17 & 21,62 & 1,43 & 0,01 & 0,30 & 0,19
\end{tabular}

${ }^{1} \mathrm{~F}=$ milho floculado, $\mathrm{FM}=$ milho floculado + monensina, $\mathrm{L}=$ milho laminado, $\mathrm{LM}=$ milho laminado + monensina.

${ }^{2}$ Erro padrão da média.

${ }^{3} \mathrm{G}=$ efeito do processamento de grão, $M=$ efeito da adição de monensina, $\mathrm{G} \times \mathrm{M}=$ interação de processamento de grão e monensina.

Embora o peso do retículo-rúmen também não tenha sido afetado pelos 
tratamentos, houve tendência de efeito do tipo de grão $(P=0,11)$, da inclusão de monensina $(P=0,13)$ e da interação destes fatores $(P=0,09)$ no peso deste compartimento expresso como porcentagem do peso do trato total (\%TT). O fornecimento de grão laminado e de monensina resultou em maior peso (\%TT) do retículo rúmen de bezerros. Beharka et al. (1998) não observou efeito significativo estudando o efeito de diferente tamanho de partícula (nível de processamento) de dieta para bezerros. No trabalho de Greenwood et al. (1998) também não foram observadas diferenças significativas no peso do retículo-rúmen de bezerros alimentados com dietas com diferentes níveis de processamento físico. Huber (1969) em sua revisão, mostrou que o peso do retículo-rúmen, quando expresso em \% TT, alcançou o valor máximo de $65 \%$ na sexta semana de vida, e não mudou com o avanço da idade.

O maior crescimento do retículo-rúmen observado nos animais recebendo LM está de acordo com a tendência de maior concentração molar de ácido butírico no rúmen de animais consumindo grãos laminados (Tabela 4). Entretanto, uma maior concentração de insulina não foi observada neste tratamento. Sakata et al. (1980) demonstraram que a insulina é um dos fatores essenciais para a proliferação de células epiteliais no rúmen, mediando o estímulo gerado pela presença de $A G V$, principalmente ácido butírico.

A capacidade do compartimento ruminal, medida em litros, sofreu efeito significativo da interação tipo de processamento de grão e inclusão de monensina (Tabela 6). O crescimento da camada muscular do rúmen está associado ao consumo de forragem (Lydorf Jr., 1988). Os animais recebendo concentrado com grãos floculados e monensina apresentaram menor capacidade ruminal, o que pode ser explicado pelo menor consumo de concentrado e feno, apesar destes efeitos não terem sido significativos. O maior consumo de feno observado nos animais recebendo grãos laminados e monensina resultou na maior capacidade ruminal, embora este valor não seja estatisticamente diferente dos tratamentos $\mathrm{Fe}$ L. Tamate et al. (1962) observaram aumento na capacidade do retículo-rúmen em 
animais que receberam esponja plástica, muito embora estas esponjas não tenham sido encontradas nestes compartimentos no abate dos animais. Segundo os autores este fato indica que o crescimento destes compartimentos não depende apenas da extensão mecânica da parede realizada por material compactado.

O peso vazio do omaso em gramas e em \% do trato total não foi afetado pelo tipo de processamento de grãos, inclusão de monensina, ou pela interação destes dois fatores. Animais recebendo dieta moída apresentaram maior peso vazio e cheio do omaso no trabalho de Beharka et al. (1998).

O peso vazio do abomaso não foi afetado pelos tratamentos. Entretanto, observou-se efeito significativo $(P=0,01)$ no peso vazio expresso como porcentagem do trato total (Tabela 6). Beharka et al. (1998) não observaram efeito de processamento de dieta no peso cheio ou vazio do abomaso. Animais recebendo grãos floculados apresentaram maior peso \%TT do abomaso. Ao nascer o abomaso é o principal compartimento do estômago de um animal ruminante. A não funcionalidade do rúmen faz com que o animal dependa da digestão realizada no estômago verdadeiro do animal. Com o avanço da idade, e com o consumo de alimento, o rúmen começa a se desenvolver de forma que as proporções dos quatro compartimentos em relação ao trato total sofra mudanças. Um maior peso em \%TT do abomaso reflete um menor desenvolvimento do rúmen em animais recebendo grãos floculados, ou seja, animais com menor consumo de concentrado.

As diferenças observadas nos pesos dos compartimentos do estômago do animal, refletem de maneira geral as diferenças observadas no consumo de alimento, no padrão de fermentação e em parâmetros sanguíneos.

\subsection{Conclusões}

O processamento d milho e a inclusão de monensina na dieta não afetaram, positiva ou negatiivamente, o desenvolvimento do rúmen de bezerros leiteiros. 
A grande variação no consumo individual de alimento, o qual acredita-se que tenha sido causada por fatores de estresse pós-cirúrgico, comprometeu a avaliação dos tratamentos. 


\section{CONCLUSÕES GERAIS}

Embora alguns dados de literatura mostrem efeitos positivos, no presente trabalho, o desenvolvimento ruminal de bezerros com até 12 semanas de vida, não foi estimulado através da suplementação de uma fonte de amido mais degradável no rúmen (milho floculado) e de monensina, a ponto de permitir uma desmama às 6 semanas de vida, com desempenho animal satisfatório. 


\section{REFERÊNCIAS BIBLIOGRÁFICAS}

ABDELGADIR, I.E.O.; MORRILL, J.L. Effect of processing sorghum grain on dairy calf performance. Journal of Dairy Science, v.78, p.2040-2046, 1995.

ALIO, A.; THEURER, C.B.; LOZANO, O.; HUBER, J.T.; SWINGLE, R.S.; DELGADOELORDUY, A.; CUNEO, P.; DeYOUNG, D.; WEEB Jr., K.E. Splanchnic nitrogen metabolism by growing beef steers fed diets containing sorghum grain flaked at different densities. Journal of Animal Science, v. 78, p.1355-1363, 2000.

ANDERSON, K.L.; NAGARAJA, T.G.; MORRIL, J.L. Ruminal metabolic development in calves weaned conventionally or early. Journal of Dairy Science, v.70, p.1000-1005, 1987a.

ANDERSON, K.L.; NAGARAJA, T.G.; MORRILL, J.L.; AVERY, T.B.; GALITZER, S.J.; BOYER, J.E. Ruminal microbial development in conventionally or early-weaned calves. Journal of Animal Science, v.64, p. 1215-1226, 1987b.

ANDERSON, K.L.; NAGARAJA, T.G.; MORRILL, J.L.; REDDY, P.G.; AVERY, T.B.; ANDERSON, N.V. Performance and ruminal changes of early-weaned calves fed lasalocid. Journal of Animal Science, v.66, p. 806-813, 1988.

ASSOCIATION OF OFFICIAL ANALYTIC CHEMISTS INTERNATIONAL. Official methods of analysis. 15. ed. Arlington, 1990. 473p. 
BAGALDO, A.R.; PIRES, A.V.; MEYER, P.M.; SIMAS, J.M.C.; SANTOS, F.A.P.; SUSIN, I. Efeito do processamento do milho e do uso de sucedâneo no desempenho de bezerros (as) da raça holandesa 1. Durante o aleitamento. In: REUNIÃO ANUAL DA SOCIEDADE BRASILEIRA DE ZOOTECNIA, 38, Piracicaba, 2001. Anais. Piracicaba: FEALQ, 2001, p.1396-1397.

BARMORE, J.A. New calf management practices enhance production efficiency. Feedstuffs, v.14, p. 12-14, 1994.

BEHARKA, A.A.; NAGARAJA, T.G.; MORRILL, G. A.; KENNEDY, G.A.; KLEMM, R.D. Effects of form of the diet on anatomical, microbial, and fermentative development of the rumen of neonatal calves. Journal of Dairy Science, v.81, p.1946-1955, 1998.

BERGEN, W.G.; BATES, D.B. Ionophores: Their effect on production efficiency and mode of action. Journal of Animal Science, v.58, p.1465-1483, 1984.

BERGMAN, E.N. Energy contributions of volatile fatty acids from the gastrointestinal tract in various species. Physiological Reviews, v.70, p.567-590, 1990.

$\mathrm{BUSH}, \mathrm{R}$. Effects of age and diet on in vitro metabolism in rumen epithelium from Holstein calves. Canadian Journal of Animal Science, v.68, p.1245, 1988.

CHANEY A.L.; MARBACH, E.P. Modified reagents for determination of urea and ammonia. Clinical Chemistry, v.8, p.130-132, 1962.

CHEN, G.C.; RUSSELL, J.B. Effect of monensin and a protonophore on protein degradation, peptide accumulation and deamination by mixed ruminal microorganisms in vitro. Journal of Animal Science, v.69, p.2196-2203, 1991.

CHEN, K.H. Effects of grain processing on lactational performance and nutrient utilization 
in dairy cows. Tucson, 1994. 130p. Dissertation (Ph.D.) - University of Arizona, Tucson.

CROWLEY, J.; JORGENSEN, N.; HOWARD, T.; HOFFMAN, P.; SHAVES, R. Raising dairy replacements. North Central Regional Extension Publication v.205, p. 62, 1991.

DANIELS, L.B.; WINNINGHAM, R.M.; HORNSBY, Q.R. Expasion-extrusion processed sorghum grain and soybeans in diets of dairy calves. Journal of Dairy Science, v.56, p. $932-934,1972$.

DAVIS, C.L.; DRACKLEY, J.K. The development, nutrition, and management of the young calf. Ames: Iowa State University Press, 1998. 339p.

DENNIS, S.M.; NAGARAJA, T.G.; BARTLEY, E.E. Effects of lasalocid or monensin on lactate producing or using rumen bacteria. Journal of Animal Science. v.52, p. 418, 1981.

DUFFIELD, T.F.; SANDALS, D.; LESLIE, K.; LISSEMORE, K.; McBRIDE, B.W.; LUMSDEN, J.H.; DICK, P.; BAGG, R. Effect of prepartum administration of monensin in a controlled-release capsule on postpartum energy indicators in lactating dairy cows. Journal of Dairy Science, v.81, p. 2354-2361, 1998.

ECONOMIDES, S.; KOUMAS, A.; GEORGHIADES, E.; HADJIPANAYIOTOU, M. The effect of barley-sorghum grain processing and forma of concentrate mixture on the performance of lambs, kids and calves. Animal Feed Science and Technology, v.31, p.105-116, 1990.

EICHER-PRUIETT, S.D.; MORRILL, J.L.; NAGARAJA, T.G.; HIGGINS, J.J.; ANDERSON, N.V.; REDDY, P.G. Response of young dairy calves with lasalocid delivery varied in feed sources. Journal of Dairy Science, v. 75, p. 857-862, 1992. 
FITZGERALD, P.R.; MANSFIELD, M.E. Efficacy of monensin against bovine coccidiosis in young Holstein-Friesian calves. Journal of Protozoology, v.20, p.121-126, 1973.

FITZGERALD, P.R.; MANSFIELD, M.E. Control of bovine coccidiosis with monensin: in nonresistant newborn calves. American Journal of Veterinary Research, v.45, p.1984-1988, 1984.

FOREYT, W.J.; RICE, D.H.; WESCOTT, R.B. Evaluation of lasalocid as a coccidiostat in calves: Titration efficacy, and comparison with monensin and decoquinate. American Journal of Veterinary Research, v. 479, p. 2031-2035, 1986.

FUNK, M.A.; GAYLENA, M.L.; ROSS, T.T. Potassium and lasalocid effects on performance and digestion in lambs. Journal of Animal Science, v.63, p. 685$691,1986$.

GÁLFI, P.; NEOGRÁDY, S.; SAKATA, T. Effects of volatile fatty acids on epithelial cell proliferation of the digestive tract and its hormonal mediaton. In: INTERNATIONAL SYMPOSIUM ON RUMEN PHYSIOLOGY, 7., Delaware, 1991. Proceedings. Delaware: Academic Press, 1991. p. 49.

GALYEAN, M.L.; HUBBERT, M.E. Rationale for use and selection of ionophores in ruminant production. In: SOUTHWEST NUTRITION AND MANAGEMENT CONFERENCE, Tucson, 1989. Proceedings. Tucson: University of Arizona, 1989. p.64.

GEORGI, J.R. Parasitology for veterinarians. 4 ed. Ithaca, New York: W.B. Saunders, 1985. 426p.

GILLILAND, R.L.; BUSH, L.J.; FRIEND, J.D. Relation of ration composition to rumen development in early-weaned dairy calves with observations on ruminal parakeratosis. Journal of Dairy Science, v.45, p. 1211-1217, 1962. 
GOODRICH, R.D.; GARRET, J.E.; GAST, D.R.; KIRICK, M.A.; LARSON, D.A.; MEISKE, J.C. Influence of Monensin on the Performance of Cattle. Journal of Animal Science, v.58, p.1484, 1984

GREEN, B.L.; McBRIDE, B.W.; SANDALS, D.; LESLIE, K.; BAGG, R.; DICK,P. The impact of a monensin controlled-release capsule on subclinical ketosis in the transition dairy cow. Journal of Dairy Science, v.82, p.333-342, 1999.

GREENWOOD, R.H.; MORRIL, J.L.; TITGEMEYER, E.E. Using dry matter intake as a percentage of initial body weight as a weaning criterion. Journal of Dairy Science, v.79, p. 2542-2546, 1997a.

GREENWOOD, R.H.; MORRIL, J.L.; TITGEMEYER, E.E.; KENNEDY, G.A. A new method of measuring diet abrasion and its effect on the development of the forestomach. Journal of Dairy Science, v.79, p.2534-2541, 1997b.

HARRISON, H.N.; WARNER, R.G.; LOOSLI, J.K. The retrogression of the rumen of dairy calves following substitution of milk for a hay-grain diet. Journal of Animal Science, v.16, p.1088-1088, 1957.

HEINRICHS, A.J.; BUSH, G.J. Evaluation of decoquinate or lasalocid against natural exposure in neonatal dairy calves. Journal of Dairy Science, v.74, p. 3223-3227, 1991.

HEINRICHS A.J.; LOSINGER, W.C. Growth of Holstein dairy heifers in the United States. Journal of Animal Science, v.76, p.1254-1260, 1998.

HEINRICHS, A.J.; DRAKE, T.R.; GARMAN, C.L. Mangement alterations to improve bovine 
coccidiosis control on dairy farms. Journal of Dairy Science, v.77, p.89, 1994.

HOBLET, K.H.; CHARLES, T.P.; HOWARD, R.R. Evaluation of lasalocid and decoquinate against coccidiosis resulting from natural exposure in weaned dairy calves. American Journal of Veterinary Research, v.50, p.1060-1063,1989.

HOFFMAN, P. Optimum body size of Holstein replacement heifers. Journal of Animal Science, v.75, p. 836-845, 1997.

HOOVER, W.H.; STOKES, S.R. Balancing carbohydrates and proteins for optimum rumen microbial yield. Journal of Dairy Science, v.74, p. 3630-3644, 1991.

HUBER, J.T. Development of the digestive and metabolic apparatus of the calf. Journal of Dairy Science, v.52, p.1303-1315,1969.

HUNTINGTON, G.B. Starch utilization by ruminants: from basis to bunk. Journal of Animal Science, v.75, p. 852, 1997.

JENNY, B.F.; VAN DIJK, H.J.; GRIMES, L.M. Performance of calves fed milk rations once daily at various fluid intakes and dry matter concentrations. Journal of Dairy Science, v.65, p. 2345-2350, 1982.

JORDAN, H.N.;PHILLIPS, R.W. Effect of fatty acids on isolated ovine pancreatic islets. American Journal of Physiology, v.234, p.162-167, 1978.

KERTZ, A.F.; RUETZEL, L.F.; MAHONEY, J.H. Ad libitum water intake by neonatal calves and its relationship to calf starter intake, weight gain, feces score, and season. Journal of Dairy Science, v.67, p. 2964-2969, 1984. 
KLEIN, R.R.; KINCAID, R.L.; HODGSON, A.S.; HARRISON, J.H.; HILLERS, J.K.; CRONATH, J.D. Dietary fiber and early weaning on growth and rumen development of calves. Journal of Dairy Science, v.70, p.2095-2104, 1987.

KRIEG, K. Calf scours. Alaska: Publication of the University of Alaska Cooperative Extension Service, 1992. 5p.

LACASSE, P.; BLOCK, E.; GUILBAULT, L.A.; PETITCLERC, D. Effect of plane of nutrition of dairy heifers before and during gestation on milk production, reproduction and health. Journal of Dairy Science, v. 76, p. 3420-3427, 1993.

LARSON, L.L.; OWEN, F.G.; ALBRIGHT, J.L.; APPLEMAN, R.D.; LAMB, R.C.; MULLER, L.D. Guidelines toward more uniformity in measuring and reporting calf experimental data. Journal of Dairy Science, v.60, p.989, 1977.

LEAVER, J.D.; YARROW, N.H. Rearing of dairy cattle. 2. Weaning according to their concentrate intake. Animal Production, v.14, p. 161-165, 1972.

LUCHINI, N.D.; LANE, S.F.; COMBS, D.K. Preweaning intake and postweaning dietary energy effects on intake and metabolism of calves weaned at 26 days of age. Journal of Dairy Science, v.76, p.255-266, 1993.

LYDORF JR., S.J. Growth and development of the ruminant digestive system. In: $\mathrm{CHURCH}, \mathrm{D} . \mathrm{C}$. The ruminant animal: digestive physiology and nutrition. Englewood Cliffs: Waveland Press, 1988. p.44-63.

MAYES, P.A. Gluconeogenesis and control of the blood glucose. In: MURRAY, R.K.; RODWELL, V.W. (Ed.) Harper's biochemistry. Prentice Hall: Appleton Lange, 1993. p.190-200. 
McDOUGALD, L.R. Monensin for the prevention of coccidiosis in calves. American Journal of Veterinary Research, v. 39, p.1748-1749, 1978.

McGUFFEY, R.K.; RICHARDSON, L.F.; WILKINSON, J.I.D. Ionophores for Dairy Cattle: Current Status and Future Outlook. Journal of Dairy Science, v. 84, p.194-203. 2001.

MOORE, J.A.; POORE, M.H.; ECK, T.P.; SWINGLE, R.S.; HUBER, J.T.; ARANA, M.J. Sorghum grain processing and buffer additions for early lactation dairy cows. Journal of Dairy Science, v. 75, p. 3465-3477, 1992.

MORRILL, J.L. Managing the calf from weaning through four months of age. In: $3^{\text {rd }}$ ANNUAL PROFESSIONAL DAIRY HEIFER GROWERS ASSOCIATION NATIONAL CONFERENCE, Minnesota, 1999. Proceedings. Washington: Washington State University Press, 1999. 226p.

MUNTIFERING, R.; THEURER, C.B.; NOON, T.H. Effects of monensin on site and extent of whole corn digestion and bacterial protein synthesis in beef steers. Journal of Animal Science, v.53, p.1565-1573, 1981.

MURDOCK, F.R.; WALLENIUS, R.W. Fiber sources for complete calf starter rations. Journal of Dairy Science, v.63, p.1869, 1980.

NAGARAJA, T.G.; AVERY, T.B.; BARTLEY, E.E.; GALITZER, S.J.; DAYTON, A.D. Prevention of lactic acidosis in cattle by lasalocid or monensin. Journal of Animal Science, v.53, p.206-215, 1981.

NATIONAL ANIMAL HEALTH MONITORING SYSTEM. National dairy heifer evaluation project: Dairy herd management practices focusing on preweaned heifers. Ft. Collins: USDA, 1993. 20p.

NATIONAL RESEARCH COUNCIL. Nutrient requirement in dairy cattle. 6. ed. 
Washington : National Academy of Science, 1989. 158p.

NATIONAL RESEARCH COUNCIL. Nutrient requirement in dairy cattle. 7. ed. Washington : National Academy of Science, 2001. 381p.

NEOGRÁDY, S.; GÁLFI, P.; KUTAS, I. Effects of butyrate and insulin and their interaction on DNA synthesis of rumen epithelial cells in culture. Experientia, v.45, p.94, 1989.

NOCEK, J.E.;TAMMINGA, S. Site of digestion of starch in the gastrointestinal-tract of dairy-cows and its effect on milk-yield and composition. Journal of Dairy Science, v.74, p. 3598-3629, 1991.

NOCEK,J.E.; HEALD, C.W.; POLAN, C.E. Influence of ration physical form and nitrogen availability on ruminal morphology of growing bull calves. Journal of Dairy Science, v. 67, p. 334-343, 1984.

NONNECKE, B.J.; FRANKLIN, S.T.; YOUNG, J.W. Effects of ketones, acetate, and glucose on in vitro immunoglobulin secretion by bovine lymphocytes. Journal of Dairy Science, v.75, p.982-990, 1992.

NUSSIO, C.M.B. Effects of decoquinate, lasalocid and monensin on performance and coccidia control in Holstein calves. Tucson, 1997. 63p. Thesis (Master) - University of Arizona.

OLIVEIRA, J.S.; HUBER, J.T.; SIMAS, J.M.; THEURER, C.B.; SWINGLE, R.S. Effect of sorghum grain processing on site and extent of digestion of starch in lactating dairy cows. Journal of Dairy Science, v.78, p. 1318-1327, 1995. 
OLIVEIRA, J.S.; HUBER, J.T.; BENGHEDALIA, D.; SWINGLE, R.S.; THEURER, C.B.; PESSARAKLI, M. Influence of sorghum grain processing on performance of lactating dairy-cows. Journal of Dairy Science, v.76, p.575-581, 1993.

OWENS, F.N.; GOETSCH, A.L. Ruminal fermentation. In: $\mathrm{CHURCH,} \mathrm{D.C.} \mathrm{The} \mathrm{ruminant}$ animal: digestive physiology and nutrition. Englewood Cliffs: Waveland Press, 1988. p.145-171.

OWENS, F.N.; ZINN, R. Protein metabolism of ruminant animals. In: $\mathrm{CHURCH,} \mathrm{D.C.} \mathrm{The}$ ruminant animal: digestive physiology and nutrition. Englewood Cliffs: Waveland Press, 1988. p.227-249.

PALMIQUIST, D.; CONRAD, H. Origin of plasma fatty acids in lactating cows fed high fat diets. Journal of Dairy Science, v.74, p. 3152, 1971.

PEREIRA, M.E.; BACKES, A.C.; SILVEIRA, A.F.; SANCHEZ, L.M.B.; VELHO, J.P.; JAURIS, G.C.; SILVEIRA, S.O. Efeito de diferentes dietas na estrutura das papilas ruminais de bezerros da raça holandesa. In: REUNIÃO ANUAL DA SOCIEDADE BRASILEIRA DE ZOOTECNIA, 38., Piracicaba, 2001. Anais. Piracicaba:FEALQ, 2001a. p.900.

PEREIRA, M.E.; BACKES, A.C.; SILVEIRA, A.F.; SANCHEZ, L.M.B.; VELHO, J.P.; JAURIS, G.C.; SILVEIRA, S.O. Efeito de diferentes dietas no desenvolvimento das papilas ruminais de bezerros da raça holandesa. In: REUNIÃO ANUAL DA SOCIEDADE BRASILEIRA DE ZOOTECNIA, 38., Piracicaba, 2001. Anais. Piracicaba:FEALQ, 2001b. p.929.

PHIPPS, R.H.; JONES, B. A.; WILKINSON, J.I.D; TARRANT, M.E. Effect of monensin on milk production of Friesian dairy cows in the United Kingdom. Journal of Dairy Science, v.78, p.268, 1995. 
PLASCENCIA, A.; ZINN, R.A. Influence of flake density on the feeding value of steamprocessed corn in diets for lactating cows. Journal of Animal Science, v.74, p.310316, 1996.

POORE, M.H.; ECK, T.P.; SWINGLE, R.S.; THEURER, C.B. Total starch and relative starch availability of feed grain. In: BIENNAL CONFERENCE ON RUMEN FUNCTION, 20., Chicago, 1989. Proceedings. Chicago: USDA, 1989. p.23-45.

PRESSMAN, B.C. Biological applications of ionophores. Annual Review of Biochemistry, v.45, p.501-527, 1976.

QUIGLEY III, J.D. Effects of lasalocid in milk replacer and calf starter on growth, intake, and fecal oocyst shedding in calves challenged with Eimeria. Journal of Dairy Science, v. 79, p.154, Suppl.1, 1996a.

QUIGLEY III, J.D. Feeding prior to Weaning. In: CALVES, HEIFERS AND DAIRY PROFITABILITY NATIONAL CONFERENCE, Pennsylvania, 1996b. Proceedings. Ithaca: Northeast Regional Agricultural Engineering Service Cooperative Extension, 1996b. p.245-255

QUIGLEY III, J.D. Influence of weaning method on growth, intake, and selected blood metabolites in Jersey calves. Journal of Dairy Science, v.79, p. 2255-2260,1996c.

QUIGLEY III, J.D. Managing the pre-weaning nutrition program. In: $3^{\text {rd }}$ ANNUAL PROFESSIONAL DAIRY HEIFER GROWERS ASSOCIATION NATIONAL CONFERENCE, Minnesota, 1999. Proceedings. Washington: Washington State University Press, 1999. 226p.

QUIGLEY III, J.D.; BERNARD, J.K. Effects of nutrient source and time of feeding on changes in blood metabolites in young calves. Journal of Animal Science, v.70, p. 
1543-1549, 1992.

QUIGLEY III, J.D.; REJMAN, J.J.; MARTIN, K.R. Response of peripheral blood mononuclear cells to mitogenic stimulation in young calves. Journal of Dairy Science, v. 77, p. $259-263,1994$.

QUIGLEY III, J.D; SCHWAB, C.G.; HYLTON, W.E. Development of rumen function in calves: Nature of protein reaching the abomasum. Journal of Dairy Science, v. 68, p. 694-702, 1985.

QUIGLEY III, J.D.; SMITH, Z.P.; HEITMANN, R.N. Changes in plasma volatile fatty acids in response to weaning and feed intake in young calves. Journal of Dairy Science, v.74, p.258, $1991 b$.

QUIGLEY III, J.D.; STEEN, T.M.; BOEHMS, S.I. Postprandial changes in selected blood and ruminal metabolites in ruminating calves fed diets with or without hay. Journal of Dairy Science, v. 75, p.228, 1992a.

QUIGLEY III, J.D.; BOEHMS, S.I.; STEEN, T.M.; HEITMANN, R.N. Effects of lasalocid on selected ruminal and blood metabolites in young calves. Journal of Dairy Science, v.75, p.2235, 1992b.

QUIGLEY III, J.D.; CALDWELL, L.A.; SINKS, G.D.; HEITMANN, R.N. Changes in blood glucose, nonesterified fatty acids, and ketones in response to weaning and feed intake in young calves. Journal of Dairy Science, v.74, p.250, 1991a.

REYNOLDS, C.K.; HUNTINGTON, H.F. Partion of portal-drained visceral net flux in beef steers. 1. Blood flow and net flux of oxygen, glucose and nitrogenous compounds across stomach and post-stomach tissue. British Journal of Nutrition, v.60, p.539$551,1988$. 
REYNOLDS, C.K.; HARMON, D.L.; CECAVA, M.J. Absorption and delivery of nutrients for milk protein synthesis by portal-drained viscera. Journal of Dairy Science, v. 77, p.2787, 1994.

ROGERS, J.A.; DAVIS, C.L. Rumen volatile fatty acid production and nutrient utilization in steers fed a diet supplement with sodium bicarbonate and monensin. Journal of Dairy Science, v.65, p. 944-952, 1982.

RUSSEL, J.B. A Proposed Mechanism of Monensin Action in Inhibiting Ruminal Bacterial Growth: Effects on Ion Flux and Protonmotive force. Journal of Animal Science, v.64, p.1519-1525, 1987.

SAKATA, T.; TAMATE, H. Rumen epithelial cell proliferation accelerated by rapid increase in intraruminal butyrate. Journal of Dairy Science, v.61, p.1109-1113, 1978.

SAKATA, T.; TAMATE, $H$. Rumen epithelium cell proliferation accelerated by propionate and acetate. Journal of Dairy Science, v.62, p.49-52, 1979.

SAKATA, T.; HIKOSAKA, K.; SHIOMURA, Y.; TAMATE, H. Stimulatory effect of insulin on ruminal epithelium cell mitosis in adult sheep. British Journal of Nutrition, v.44, p.325-331, 1980.

SANTOS, F.A.P.; SANTOS, J.E.P.; THEURER, C.B.; HUBER, J.T. Effects of rumen undegradable protein on dairy cow performance: a 12-year literature review. Journal of Dairy Science, v.81, p.3182-3213, 1998.

SAUER, F.D.; KRAMER, J.K.G.; CANTWELL, W.J. Antiketogenic effects of monensin in early lactation. Journal of Dairy Science, v.72, p.436-442, 1989.

SAS INSTITUTE. SAS users guide: Statistics, version 5. Cary, 1991. 1028p. 
SCHUH, J.D.; HALE, W.H.; THEURER, C.B. Pressure cooking versus steam processing and flaking sorghum grain for dairy calves. Journal of Dairy Science, v.53, p.401, 1971.

SCHUH, J.D.; LIMA, J.O.A.; HALE, W.H.; THEURER, C.B. Steam-processed flaked grains versus steam-rolled grains for dairy calves. Journal of Dairy Science, v.53, p.475, 1970.

SERJSEN, K. Relationship between nutrition puberty and mammary development in cattle. Proceedings of the Nutrition Society, v.53, p.103-111, 1994.

SIMAS, J.M. Processamento de grãos para rações de vacas leiteiras. In: SIMPÓSIO SOBRE PRODUÇÃO ANIMAL, 9., Piracicaba, 1997. Anais. Piracicaba: FEALQ, 1997. p.7-32.

SINKS, G.D., QUIGLEY III, J.D., REINEMEYER, C.R. Effects of lasalocid on coccidial infection and growth in young dairy calves. Journal of the American Veterinary Medicine Association, v.200, p.1947, 1992.

SPEARS, J.W. Ionophores and Nutrient Digestion and Absorption in ruminants. Journal of Nutrition, v.120, p.632-638, 1990.

STOCKDALE, P.H.G.; SHEARD, A.; TIFFIN, G.B. Resistance to Eimeria bovis produced after chemotherapy of experimental infections in calves. Veterinary Parasitology, v.9, p.171-177, 1982.

STROMBERG, B.E.; SCHLOTTHAWER, J.C.; HAMANN, K.J.; SAATARA, H.; BEMRICK, W.J. Experimental bovine coccidiosis: Control with monensin. Veterinary Parasitology, v.22, p.135-140, 1986. 
SUTTON, J.D.; McGILLIARD, A.D.; JACOBSON, N.L. Functional development of rumen mucosa. I. Absorptive ability. Journal of Dairy Science, v. 46, p. 426-436, 1963.

TAMATE, H. ; McGILLIARD, A.D.; JACOBSON, N.L. ; GETTY, R. Effect of various dietaries on the anatomical development of the stomach in the calf. Journal of Dairy Science, v.45, p.408-420, 1962.

TARGOWSKI, S.P. ; KLUCINSKI, W. Reduction in mitogenic response of bovine lymphocytes by ketone bodies. American Journal of Veterinary Research, v. 44, p.828, 1983.

TARGOWSKI, S.P. ; KLUCINSKI, W.; LITTEDICKE, E.T.; HOY, D.A. Suppression of mitogenic response of bovine lymphocytes during experimental ketosis in calves. American Journal of Veterinary Research, v.46,p.1378, 1985.

THEURER, C.B. Grain processing effects on starch utilization by ruminants. Journal of Animal Science, v. 63, p.1694, 1986.

THEURER,C.B.; LOZANO, O.; ALIO, A. Ruminal vs. Intestinal starch digestion affects nutrient use and efficiency of gain of feedlot cattle. SOUTHWEST NUTRITION AND MANAGEMENT CONFERENCE, Tucson, 1996. Proceedings. Tucson: University of Arizona, 1996. p. 97-108.

THEURER, C.B.; J.T. HUBER; DELGADO-ELOURDY, A. Steam flaking improves starch utilization and milk production parameters. In: CORNELL NUTRITION CONFERENCE FOR FEED MANUFACTURES, Rochester, 1996a. Proceedings. Rochester: Cornell University, 1996a. p.121-130.

THEURER, C.B.; HUBER, J.T.; DELGADO-ELORDUY, A.; WANDERLEY, R. Invited 
review: Summary of steam-flaking corn or sorghum grain for lactating dairy cows. Journal of Dairy Science, v.82, p. 1950-1959,1999.

THICKETT, W.S.; CUTHBERT, N.H.; BRIGSTOCKE, T.D.A.; LINDEMAN, M.A.; WILSON, P.N. The management of calves on an early-weaning system: the relationship of voluntary water intake and live weight gain to 5 weeks. Animal Production, v.33, p.25-30, 1981.

THORNTON, J.H.; OWENS, F.N. Monensin Supplementation and in vivo Methane Production by Steers. Journal of Animal Science, v. 52, p.628-634, 1981.

TOMKINS, T.; SOWINSKI, J.S.; DRACKLEY, J.K., DAVIS, C.L.; KEITH, N.K. The influence of protein level in milk replacers on growth and performance of male Holstein calves. II. All milk protein milk replacer fed in conjunction with calf starter. Abstr. Journal of Dairy Science, v.78, p.233, 1995.

TRENKLE, A.; KUHLEMEIER, K.V. Relationship of rumen volatile acids, blood glucose and plasma nonesterified fatty acids in sheep. Journal of Animal Science, v. 25, p. 1111, 1966.

VAN NEVEL, C.J.; DEMEYER, D.I. Manipulation of rumen fermentation. In: The rumen microbial ecosystem. London: Elsevier Applied Animal Science, 1988. 387p.

VAN SOEST, P.J. Nutritional ecology of the ruminant. Ithaca: Cornell University Press, 1994. 476p.

VAN SOEST, P.J.; ROBERTSON, J.B.; LEWIS, B.A. Methods for dietary fiber neutral detergent fiber, and non-starch polysaccharides in relation to animal nutrition. Journal 
of Dairy Science, v.74, p.3583-3597, 1991.

WAGGONER,J.K.; CECAVA, M.J.; KAZACOS, K.R. Efficacy of lasalocid and decoquinate against coccidiosis in naturally infected dairy calves. Journal of Dairy Science, v.77, p.349-353, 1994.

WARNER, R.G. Nutritional factors affecting the development of a functional ruminant - a historical perspective. In: CORNELL NUTRITION CONFERENCE, Ithaca, 1991. Proceedings. Ithaca: Cornell University, 1991. p. 1-12.

WATKINS, L.E.; WRAY, M.I.; BASSON, R.P.; FELLER, D.L.; OLSON, R.D.; FITZGERALD, P.R.; STROMBERG, B.E.; DAVIS, G.W. The prophylactic effects of monensin fed to cattle inoculated with coccidia oocysts. Agri-Practice, v.7, p.18-20, 1987.

WEIGAND, E.; YOUNG, J.W.; McGILLIARD, A. D. Extent of butyrate metabolism by the ruminoreticulum epithelium and the relationship to absorptive rate. Journal of Dairy Science, v.55, p.589-597, 1972.

WHETSTONE, H.D.; DAVIS, C.L.; BRYANT, M.P. Effect of monensin on breakdown of protein by ruminal microorganisms in vitro. Journal of Animal Science, v.53, p.803809, 1981.

WILLIAMS, C.C.; THOMPSON Jr., D.L.; BATEMAN II, H.G.; JENNY, B.F.; GANTT, D.T.; GENTRY, L.R.; GOODIER, G.E.; AND CHEATHAM, C.M. Effects of dietary protein and weaning age on hormone and metabolite concentrations in neonatal dairy calves. Journal of Dairy Science, v. 84, Suppl.1, p. 226, 2001.

WILLIAMSON, D.H.; MELLANBY, J.; KREBS, H.A. Enzymatic determination of D(-)Bhydroxybutyric acid and acetoacetic acid in blood. Biochemical Journal, v.82, p.90, 1962. 
WINTER, K.A. Comparative performance and digestibility in dairy calves weaned at three, five, and seven weeks of age. Canadian Journal of Animal Science, v.65, p.445-450, 1985

YOKOYAMA, M.T.; JOHNSON, K.A. Microbiology of the rumen and intestine. In: $\mathrm{CHURCH}$, D.C. The ruminant animal: digestive physiology and nutrition. Englewood Cliffs: Waveland Press, 1988. p.125-144.

YU, P. Effect of corn grain processing on lactational performance, nutrient utilization and metabolism in dairy cows. Tucson, 1996. 126p. Dissertation (Ph.D.) - University of Arizona. 